1.9

العدد العشرون لسنة 9 1 • r م

مجلة البحث العلمى فى التربية

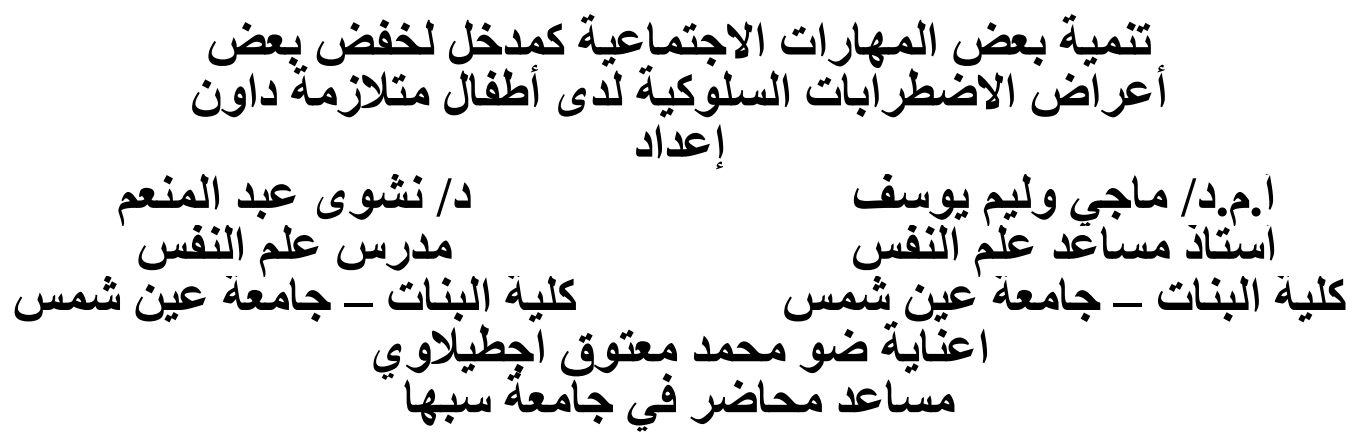


$\wedge 1$.

$$
\text { العدد العشرون لسنة } 9 \text { ا م م م }
$$

$$
\text { مجلة البحث العلمى فى التربية }
$$

$$
\text { مستخلص البحث المباث }
$$

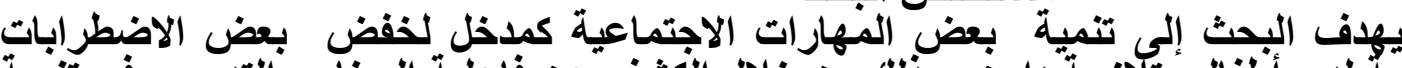

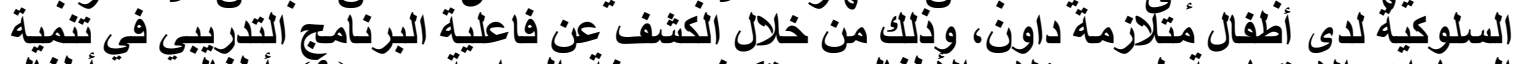

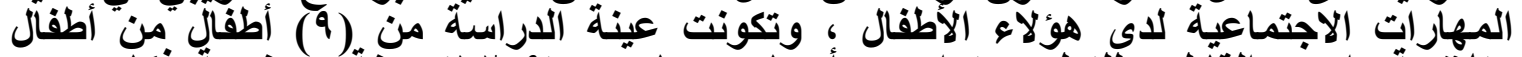

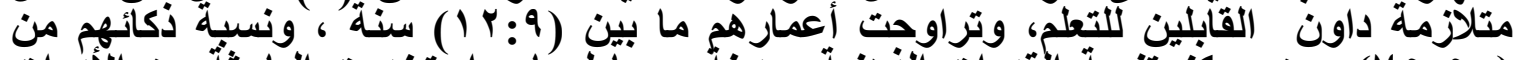
(V0:0:)

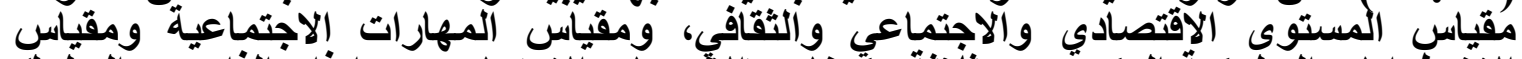

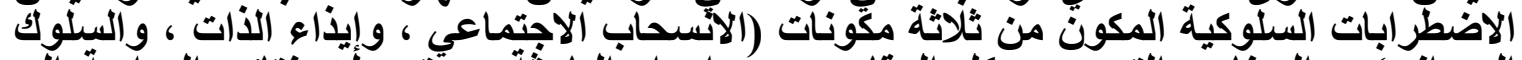

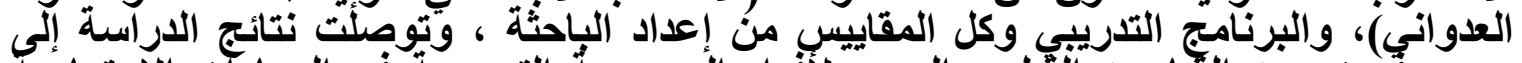

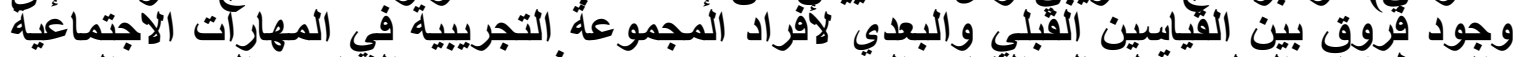

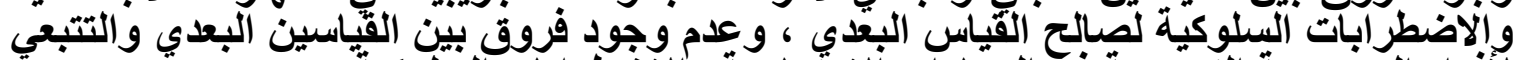

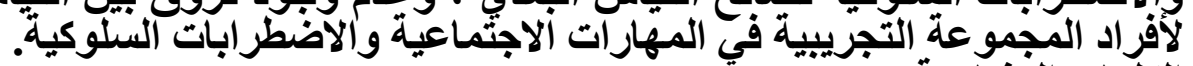

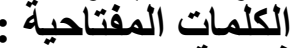

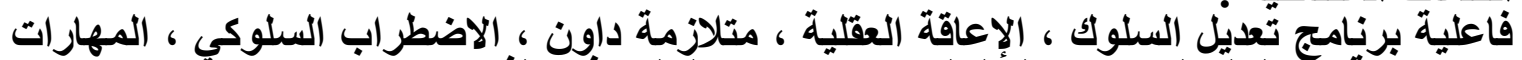

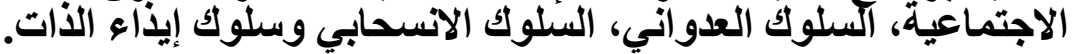

\section{Abstract :}

The research aims to development some social skills as an input to reduce some behavioral disorders in children with Down Syndrome، and that through the disclosure of the effectiveness of the training program in the development of social skills of these children'the study sample consisted of 9 children with Down syndrome who are educable mentally retarded, their ages ranged from (9:12) years, and the ratio of intelligence from (50:75) from the Center for the development of mental abilities in the city of Sabha Libya، the researcher used from the tools measure of the economic level, social, cultural and measure of the social skills and measure of behavioral disorders, consisting of three components (social withdrawal, self-harm, aggressive behavior), the training program and all measurements prepared by the researcher' the results of the study found that there are differences between the two measurements pre and post and absence of differences between the two measurements post and follow-up of members of the experimental group in social skills and behavioral disorders.

Key words :

The effectiveness of program behavior modification, mental retardation, Down syndrome, behavior disorder, social skills, aggressive behavior, withdrawal behavior and self-harm behavior.

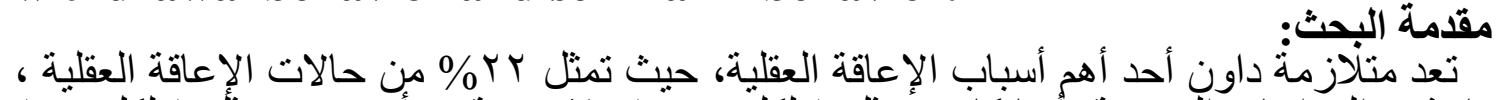

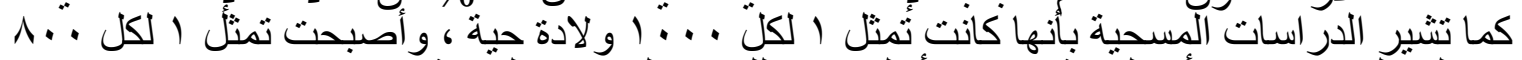

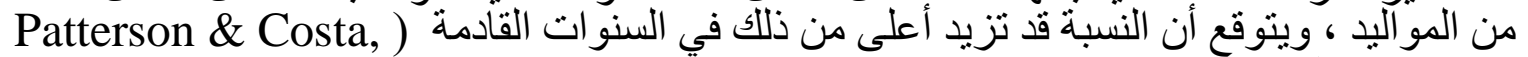

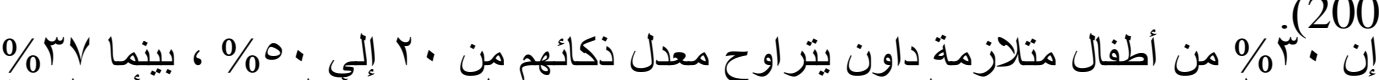

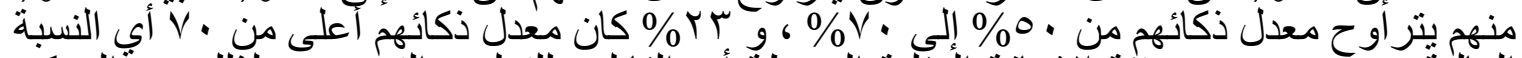

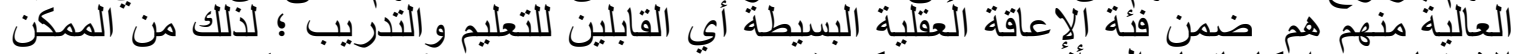

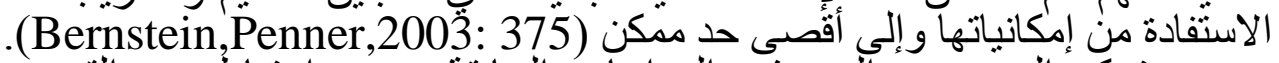

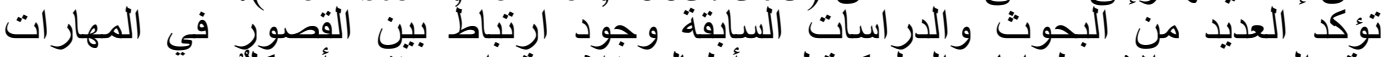

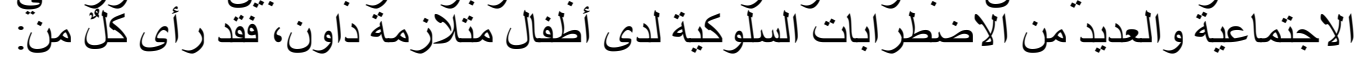

(Quintana, Anestacol, 2004; Sturge \& Apple et al. 2006; Graziano et al.

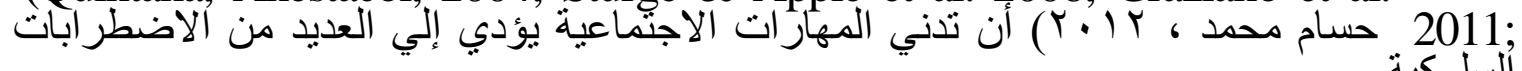


وقد أشـارت دارسة كيربي (2004) Kerby إلي وجود علاققة بين المهار ات الاجتماعية و العديد

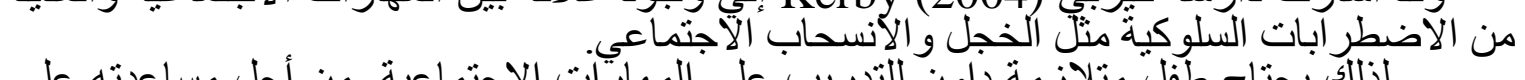

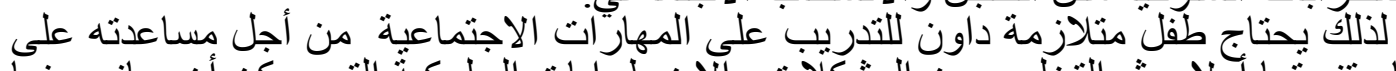

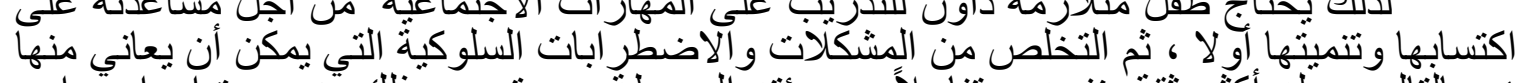

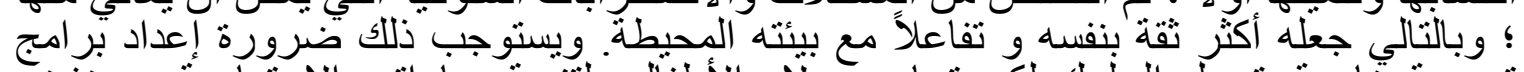

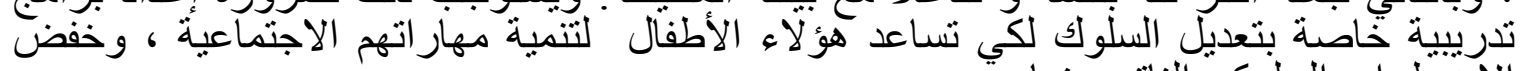

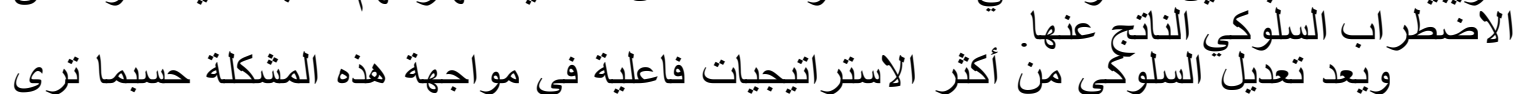

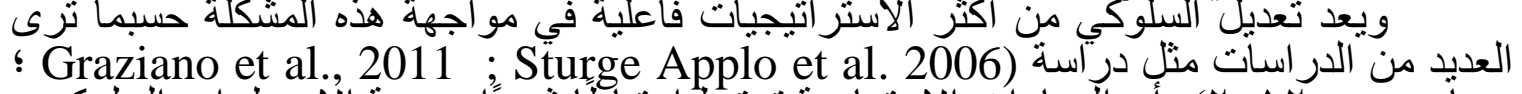

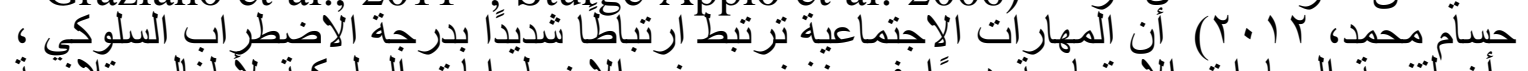

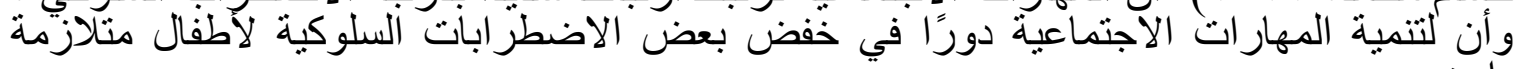

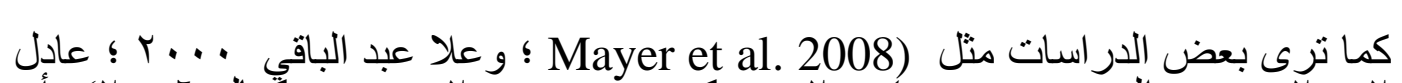

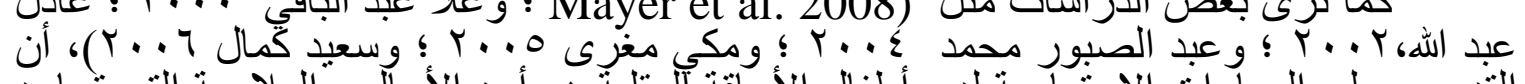

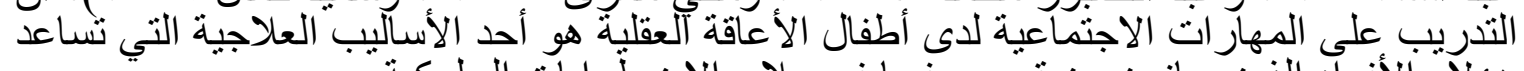

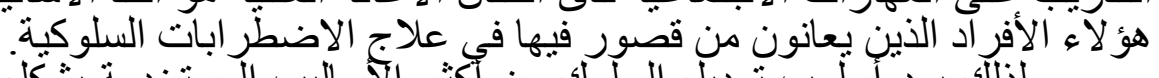

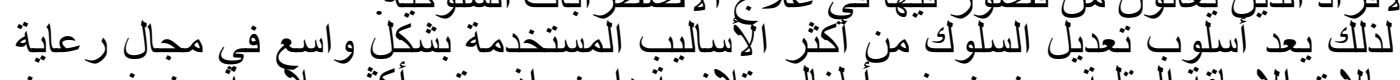

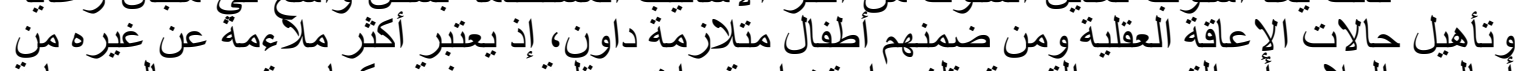

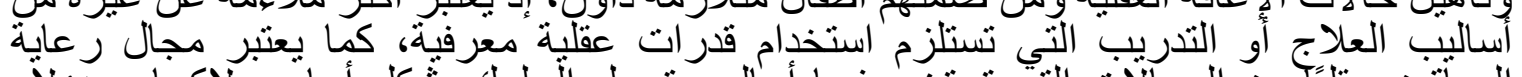

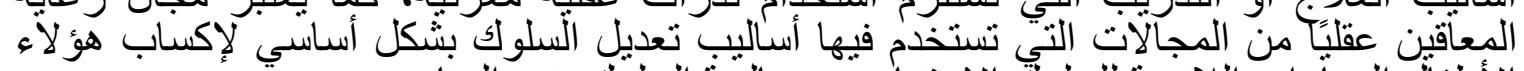

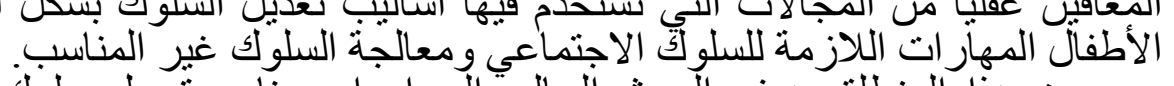

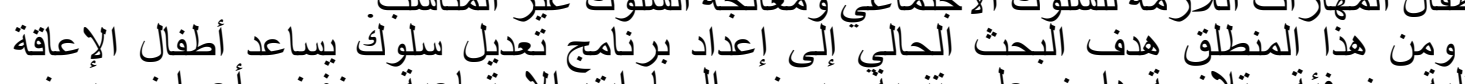

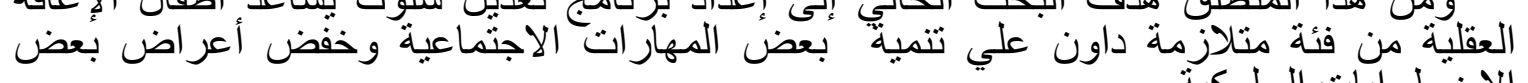
الاضنّر ابات السلوكية.

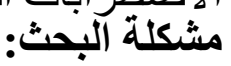

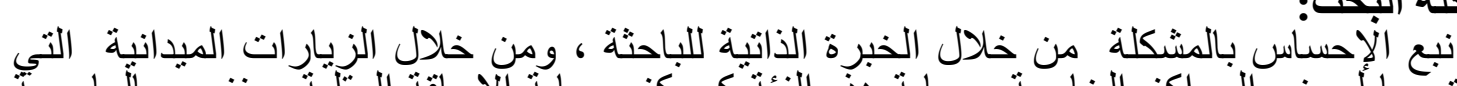

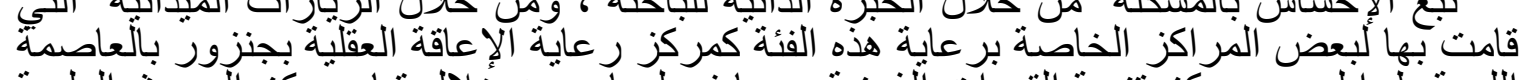

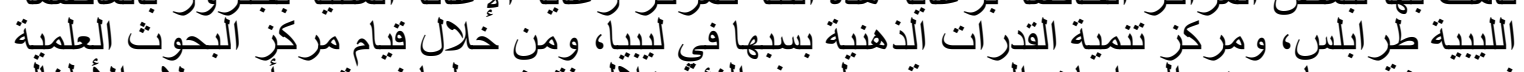

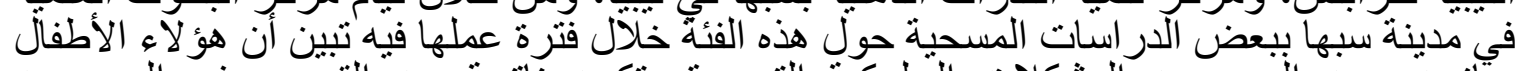

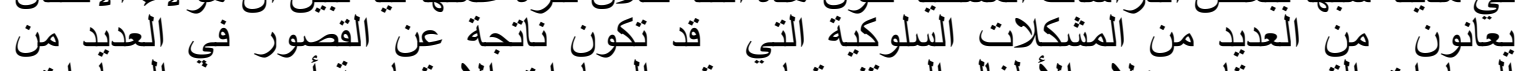

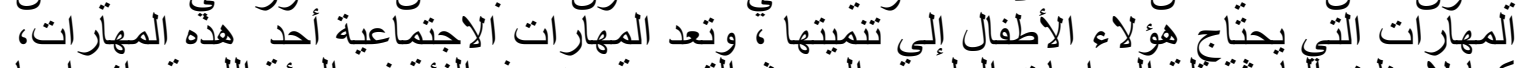

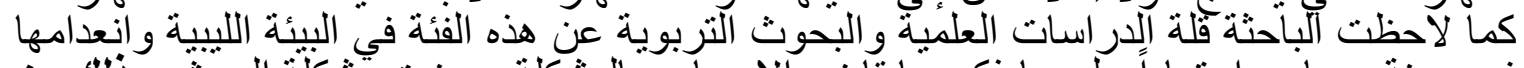

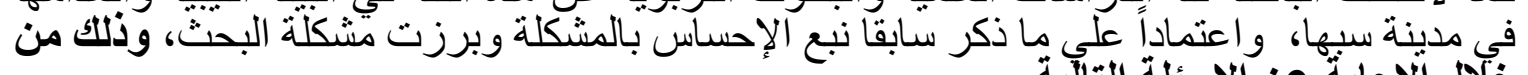

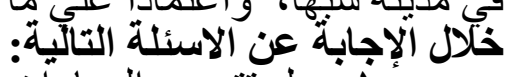

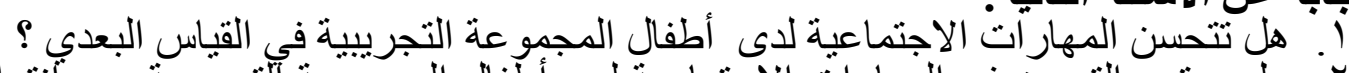

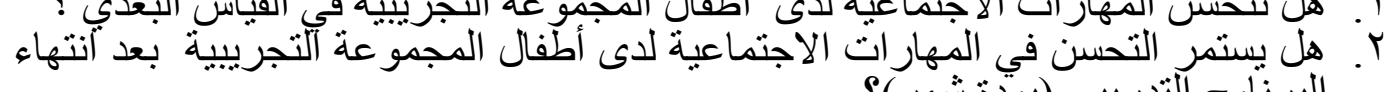

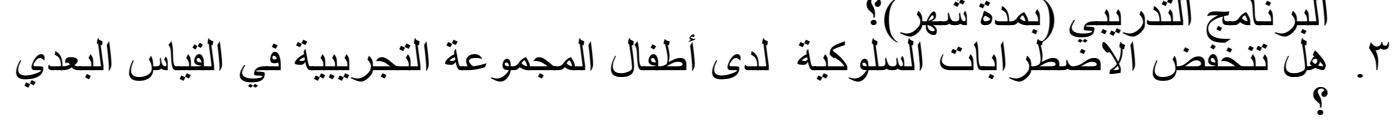
ع. هل ئنتمر الانخفاض في الاضطر ابات السلوكية لدى أطفال المجموعة التجريبية بعد

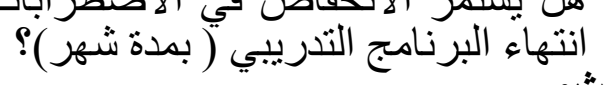

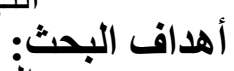
هدف البّثث إلى معرفة فاعلية تنمبة بعض المهار ات الاجتماعية لأطفال متلازمة داون في

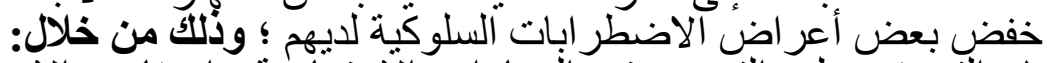

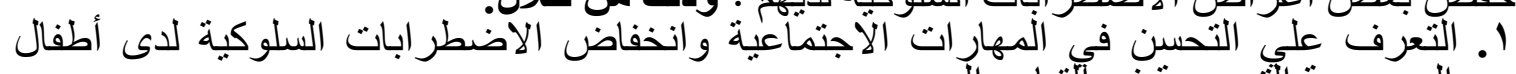

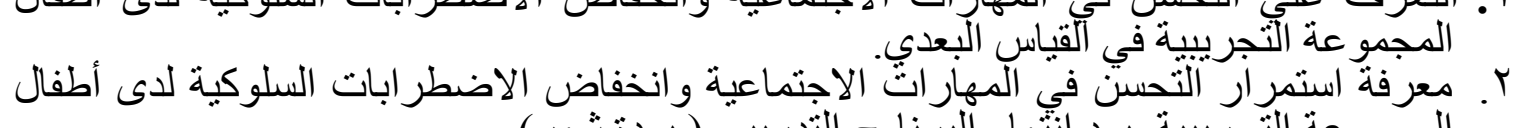

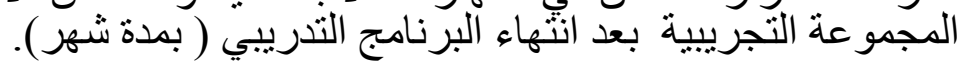




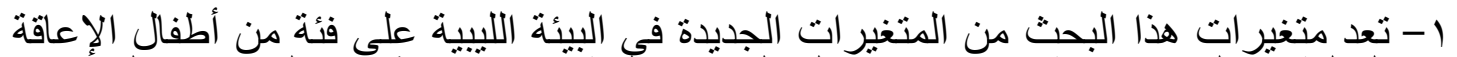

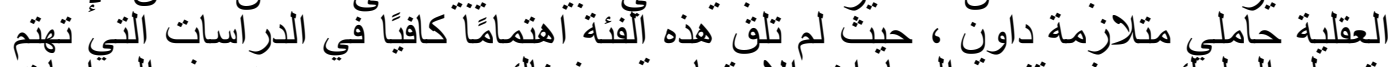

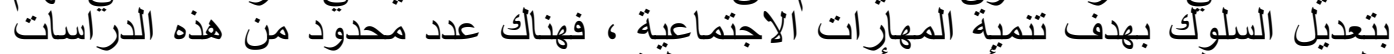

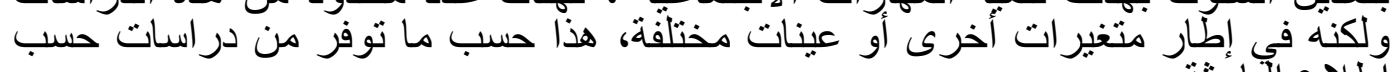
اطنالع الباحثنة.

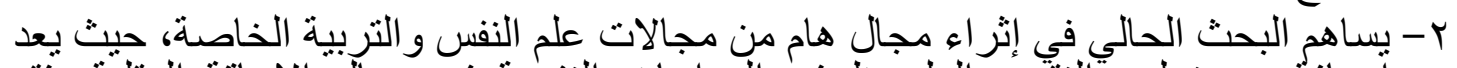

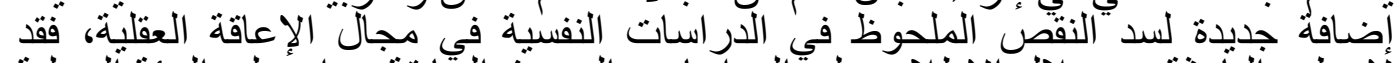

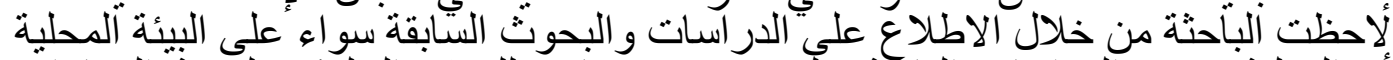

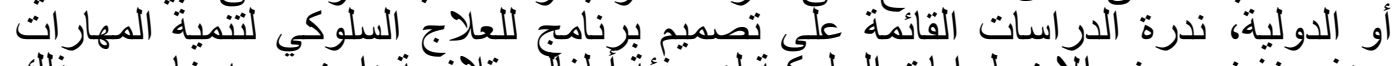

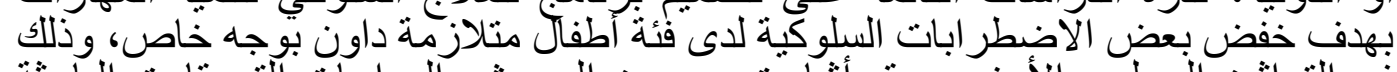

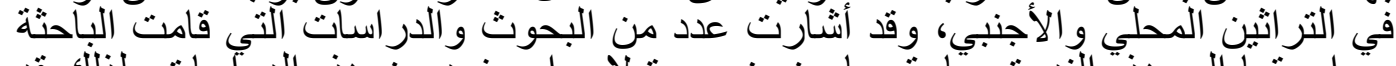

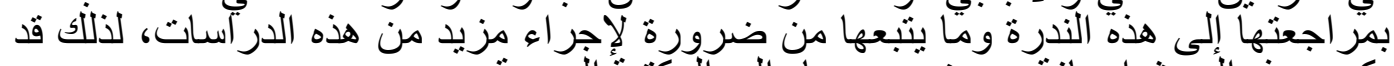

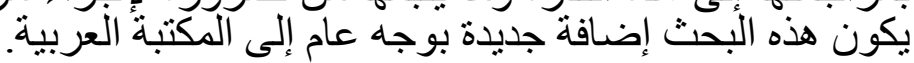

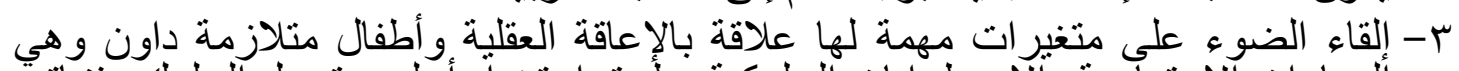

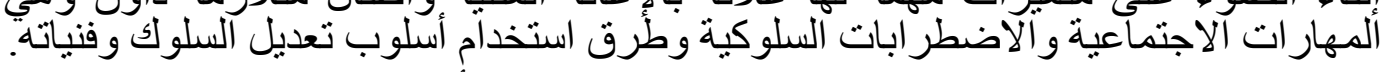

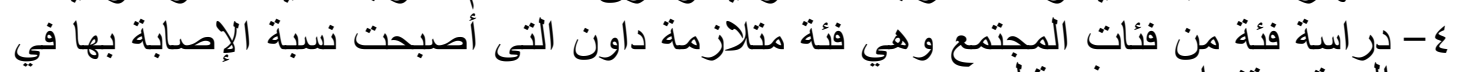

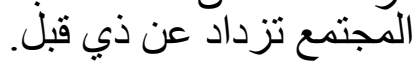

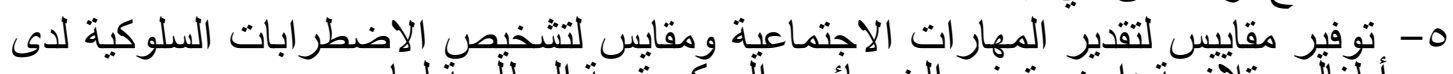

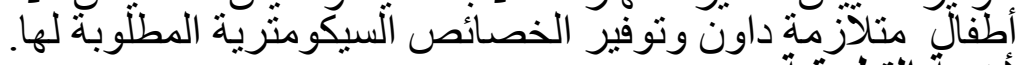

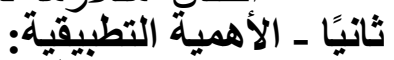

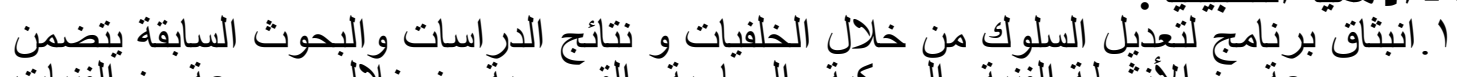

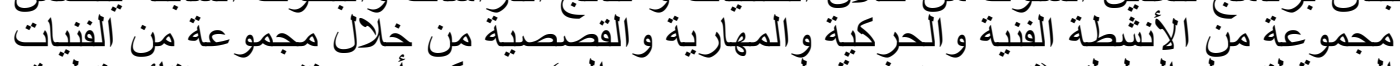

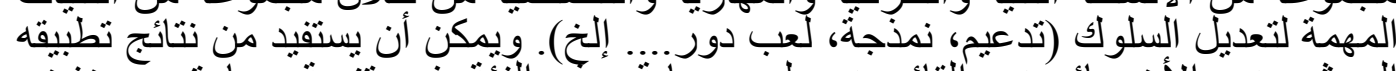

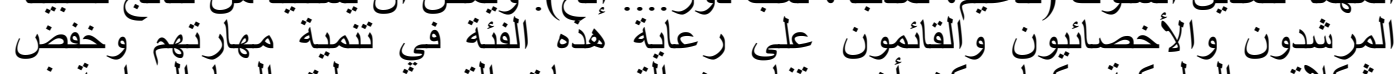

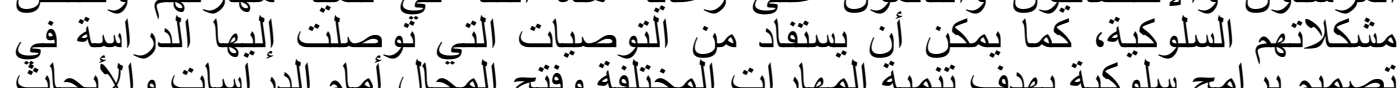

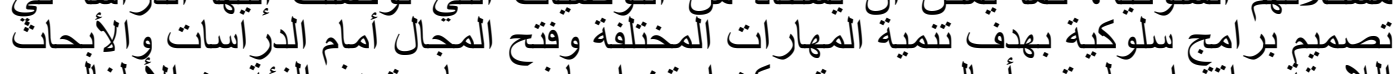

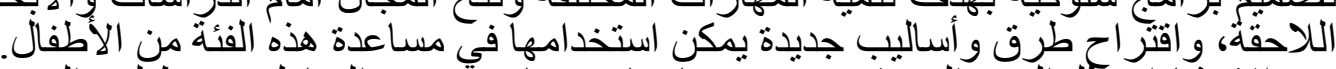

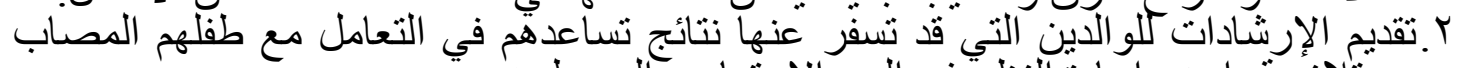

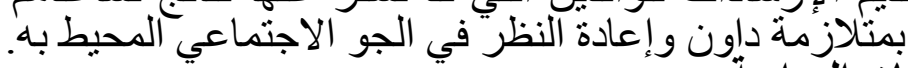

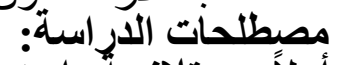

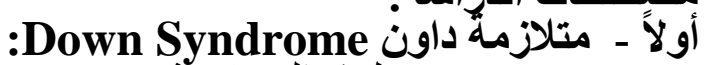

ورد تعريف لهذه المتلازمة فئ في معجم لعلم النفس بأنها إحدى الفئات الكيلنيكية للإعاقة العقلية

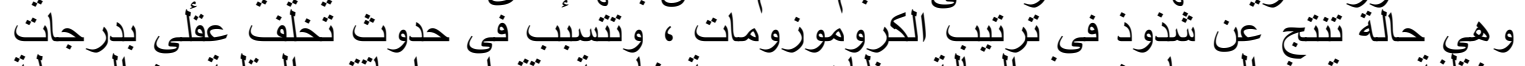

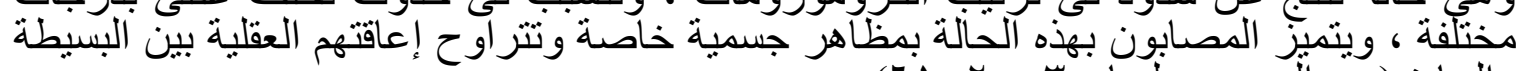

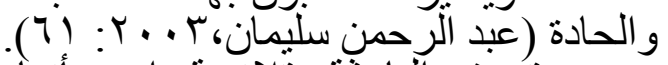

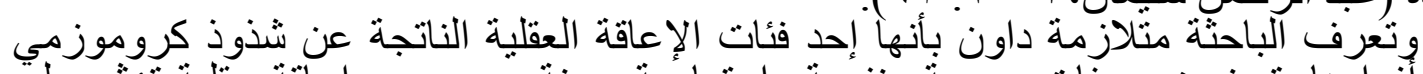

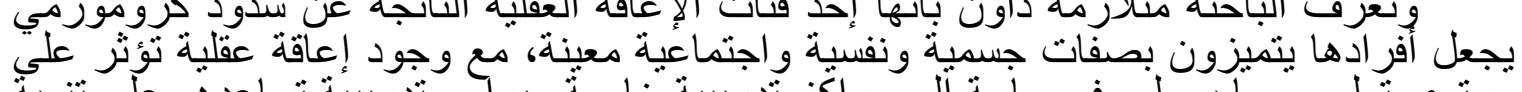

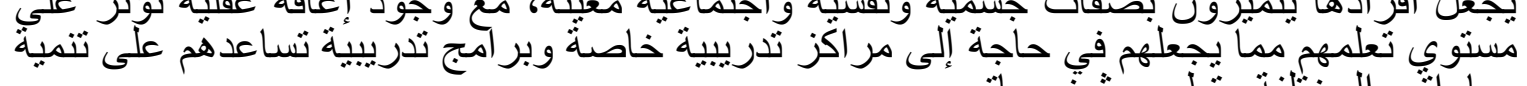

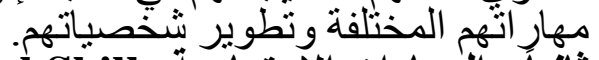
ثانياً - المهارات الأجتماعية Social Skills:

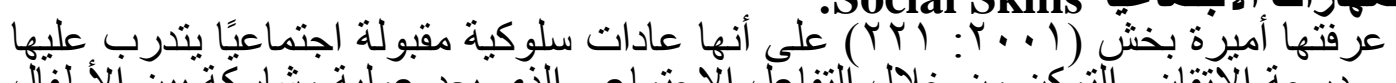

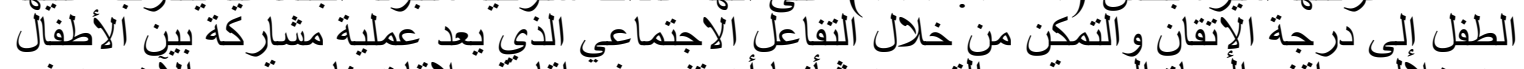

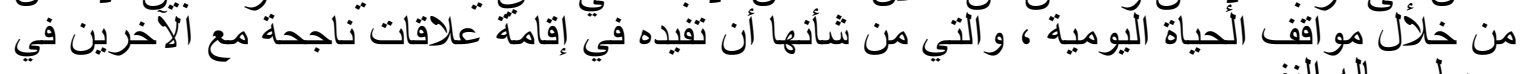

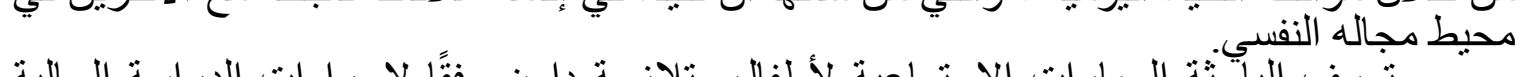

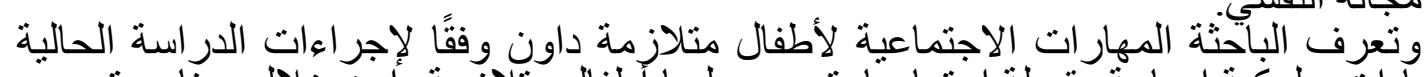

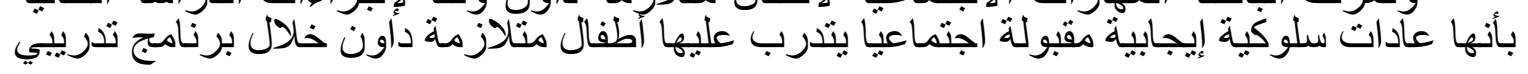




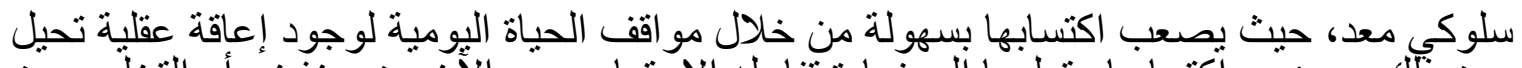

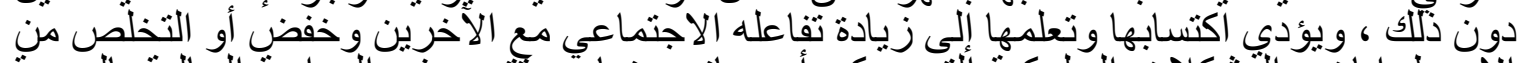

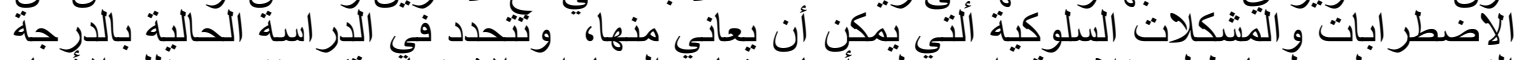

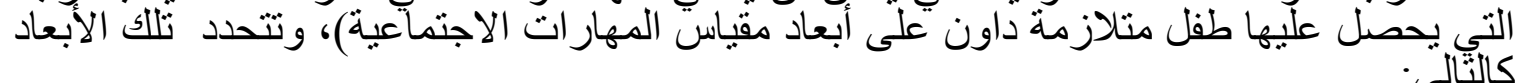

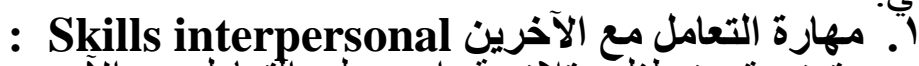

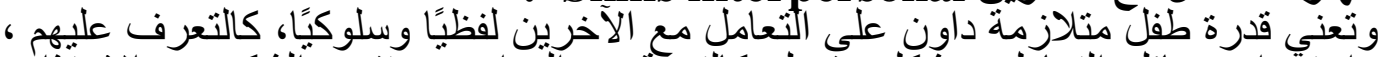

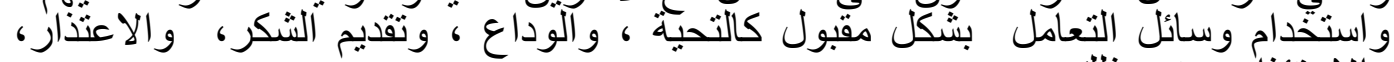

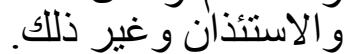

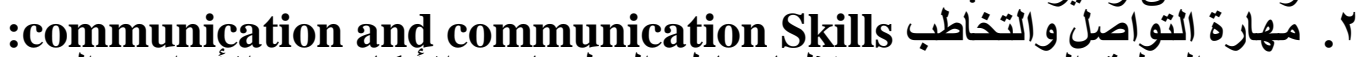

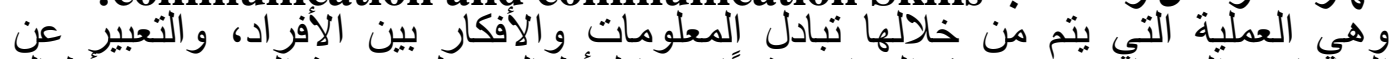

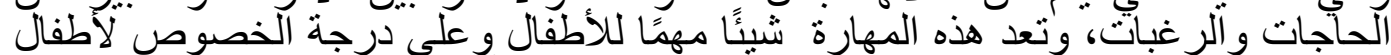

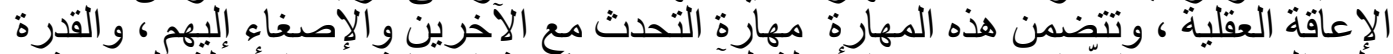

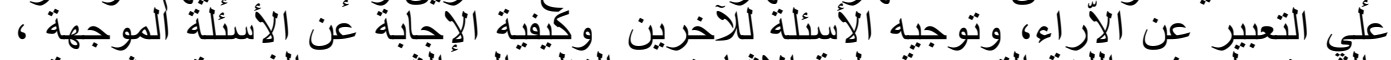

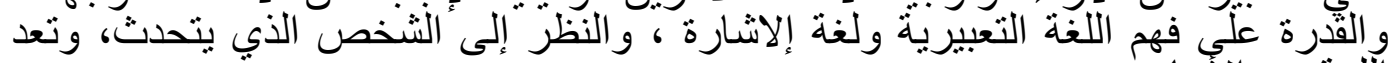

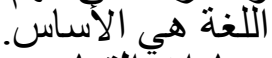

r. مهار ات" التعاون والمشاركة

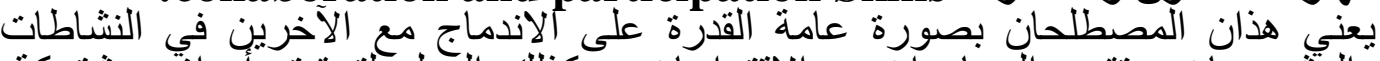

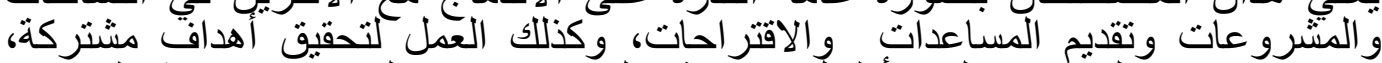

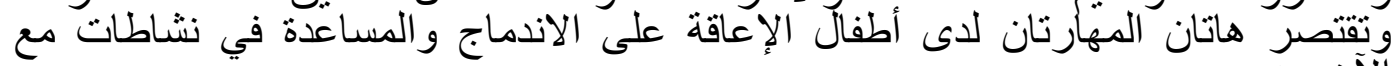

ع. مهاراتين. الاستقلالية وتحمل المسؤلية

:Skills

وهي قدرة الفرد على الاعتماد على نفسه، والثقة بها والإحساس بقيمة الذات، واحترام

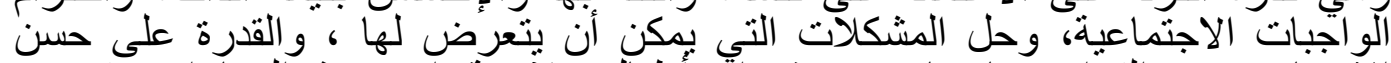

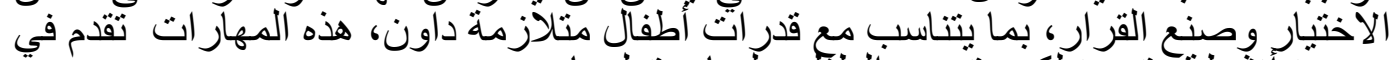

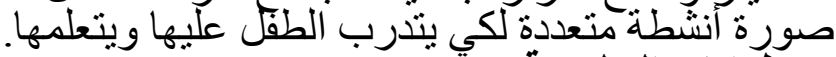

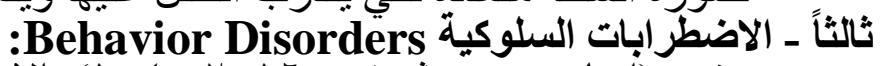

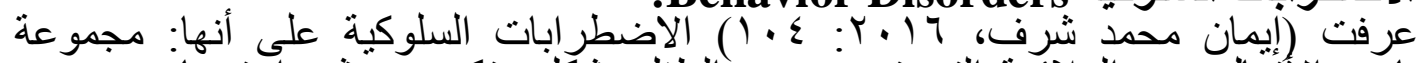

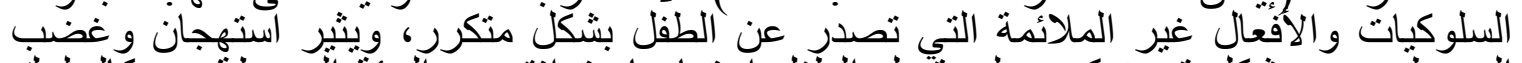

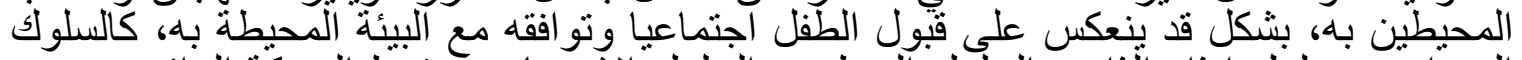

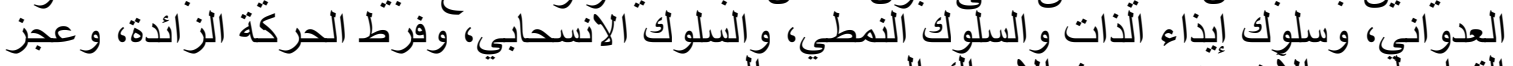

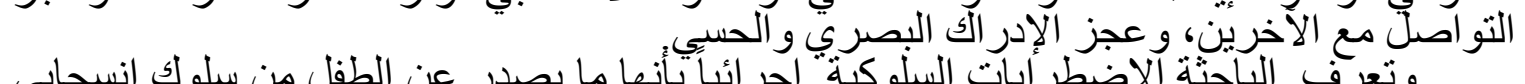

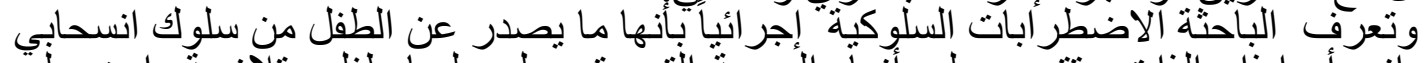

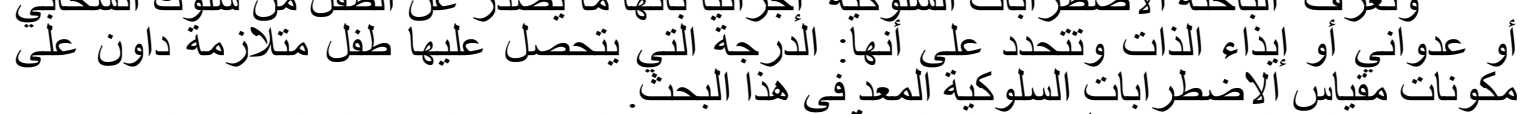

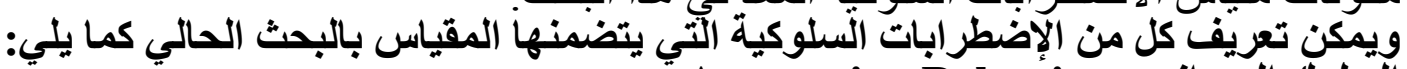
السلوك العدواني :Agressive Behavior

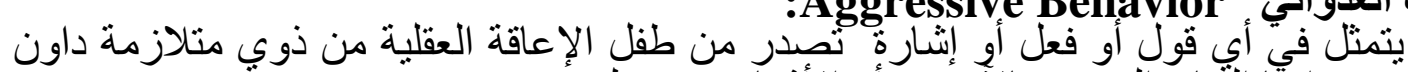

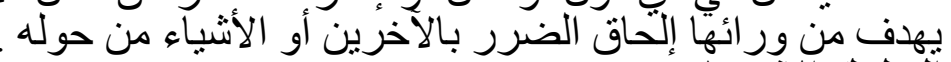
ألسلوك الانسحابي:Withdrawal Behavior: يتمثل بإبعَاد الطفل نفسه عن مجرى الحياة الاجتماعية العادية، ويصاحب ذلك عدم التعاون

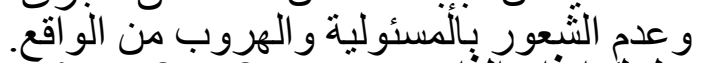

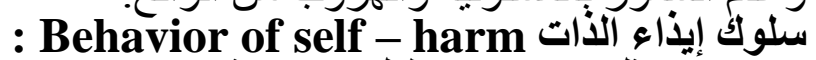

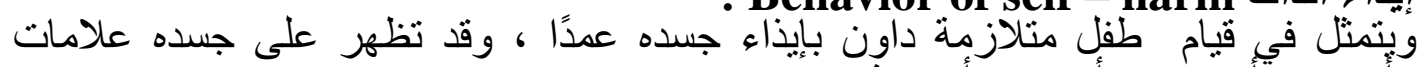

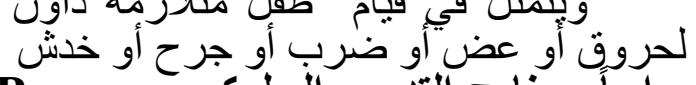
رابعأ- برنامج التدريب السلوكي Behavioral Training Program:

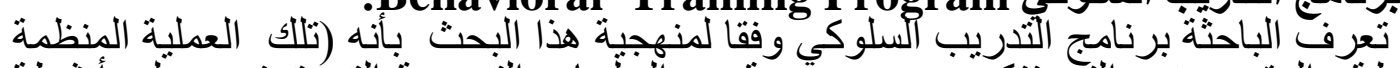

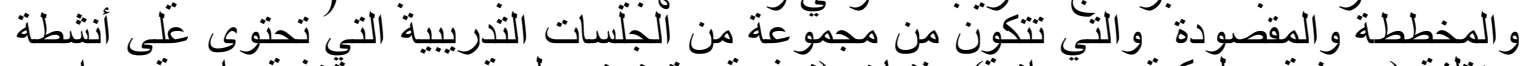

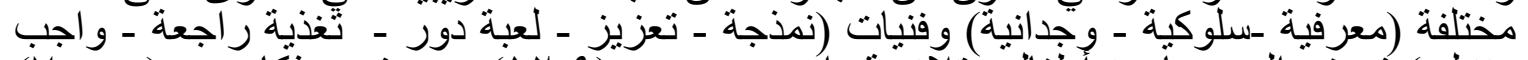

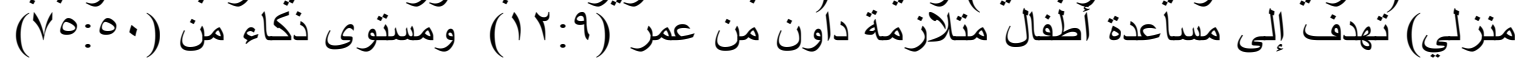


لإكسابهم بعض المهار ات الاجتماعية (التعامل مع الآخرين ، المشاركة و التعاون، تحمل المسئولية،

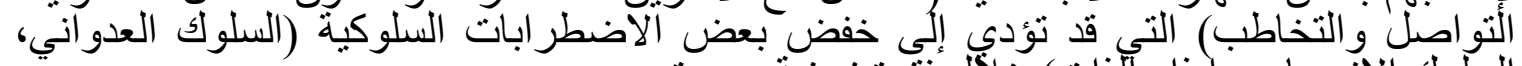

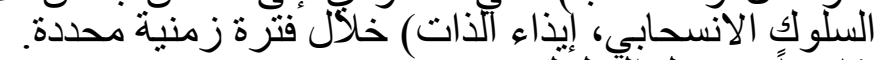

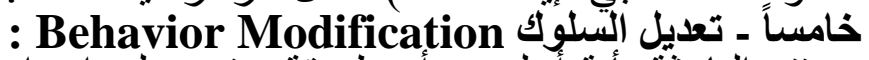

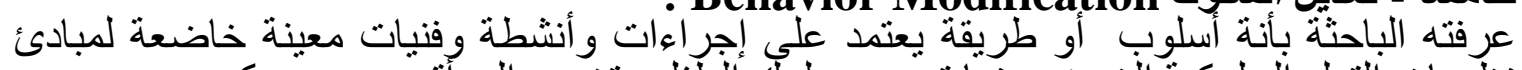

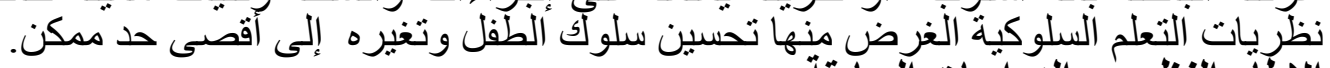
الإطار النظري والثطل الدراسات الكابقة:

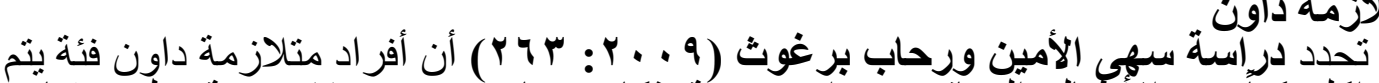

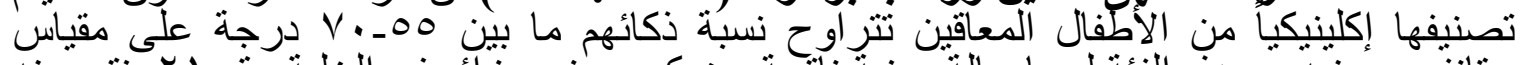

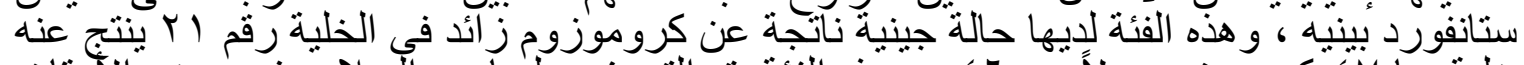

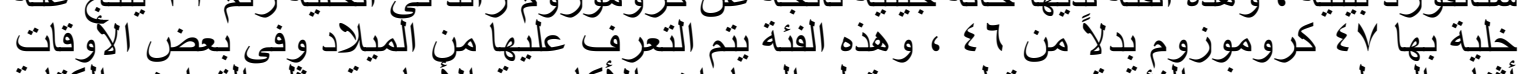

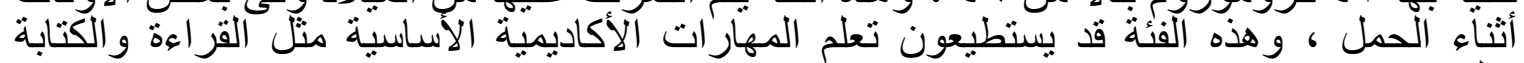

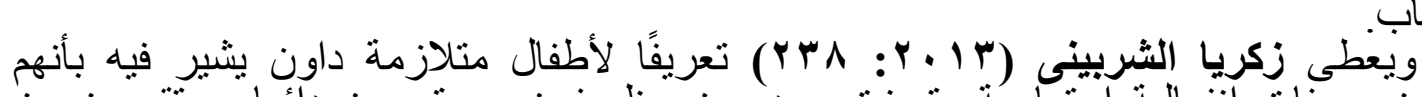

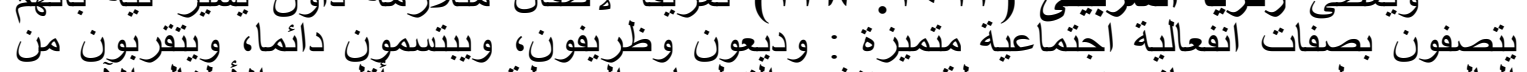

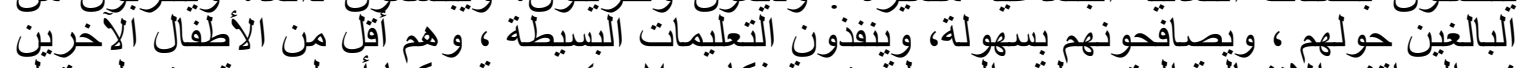

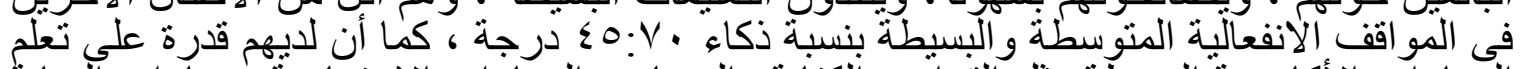

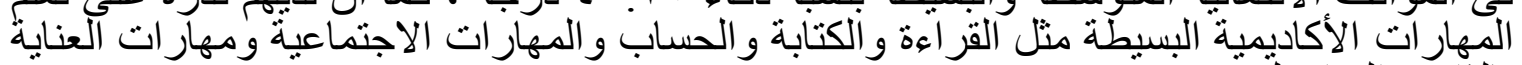

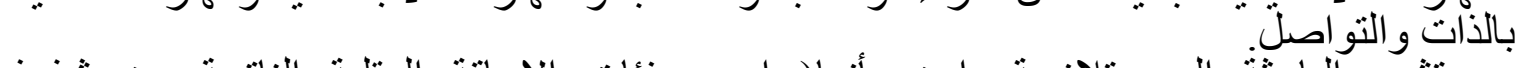

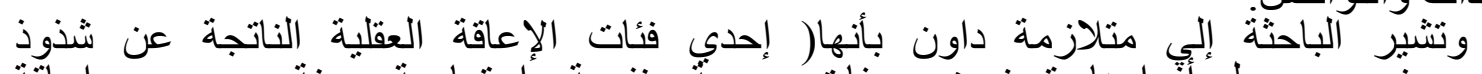

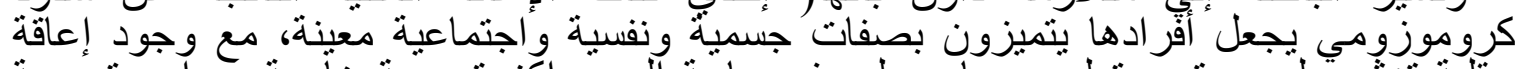

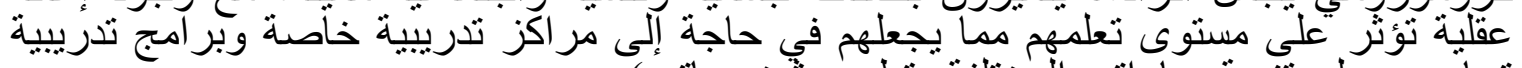

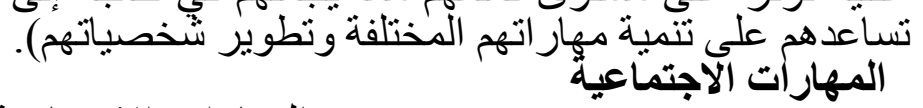

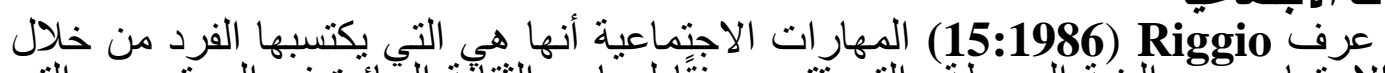

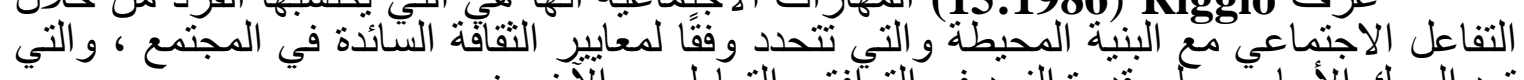

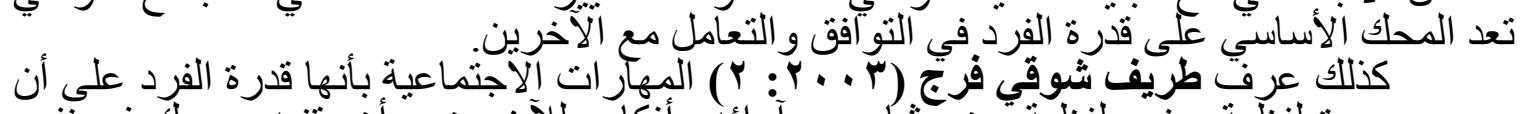

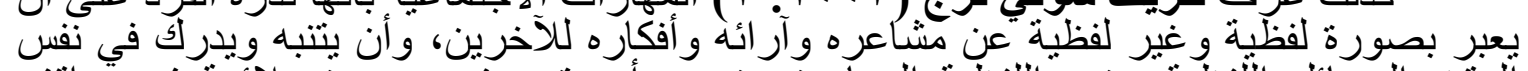

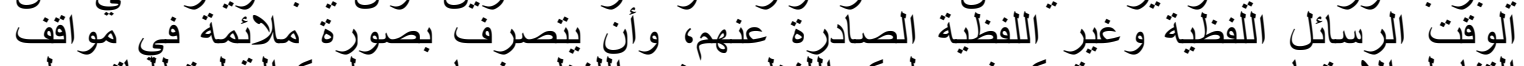
التفاعل الاجتماعي معهم، ويتحكم في سلوكه اللفظي وغير اللفظي فيها ويعد له كدالة لمنطلتباته على

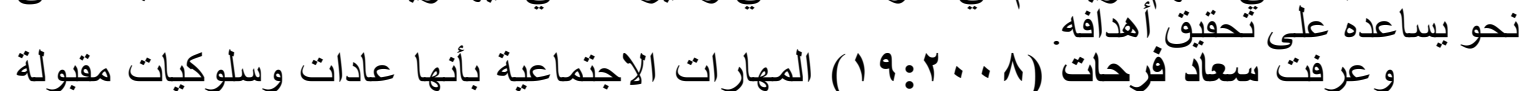

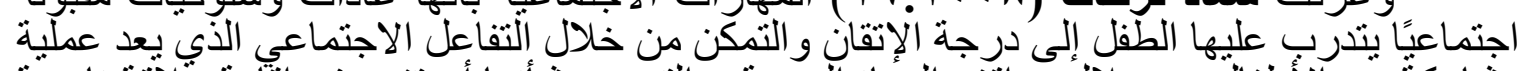

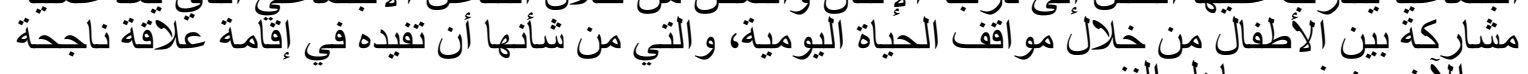

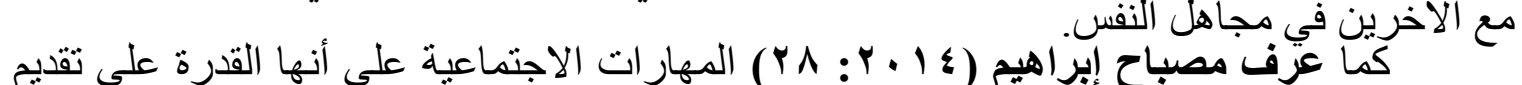

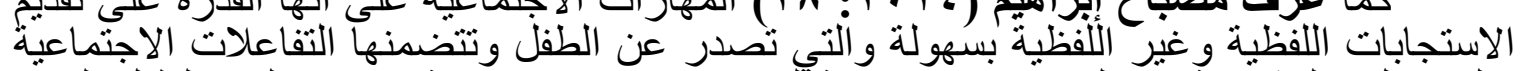

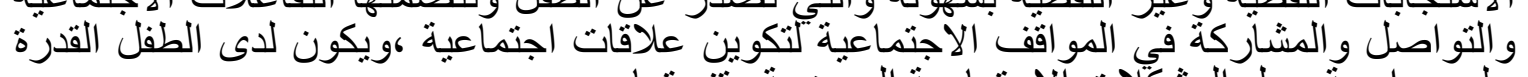

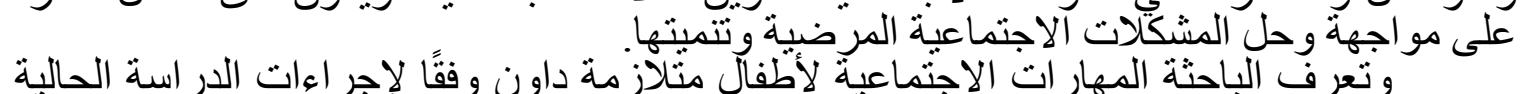

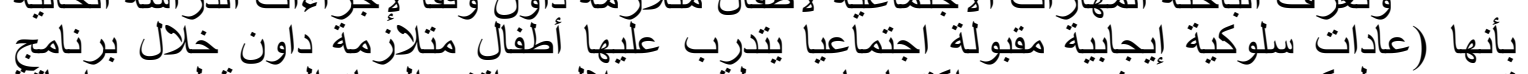

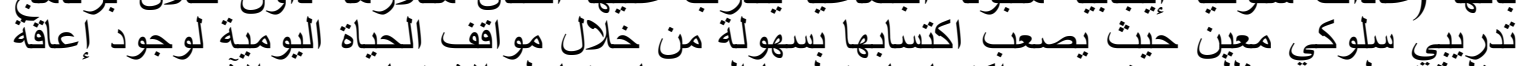

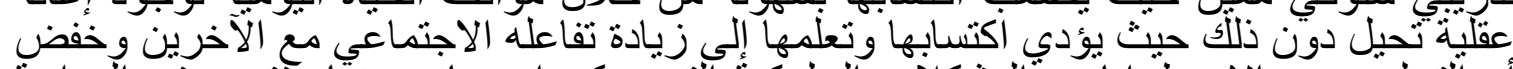

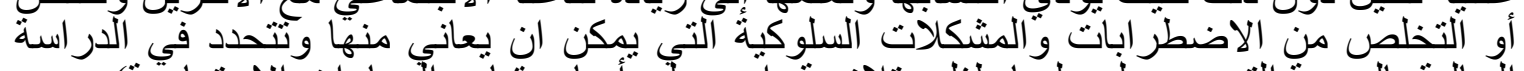

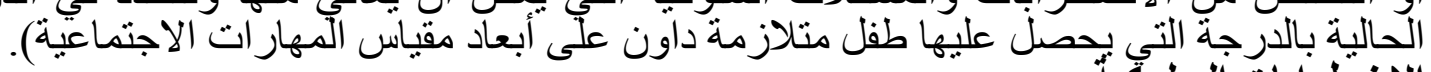
الاضطرابات ألسلوكية التية

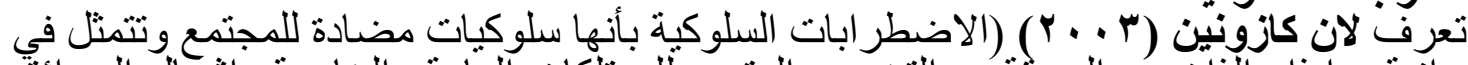

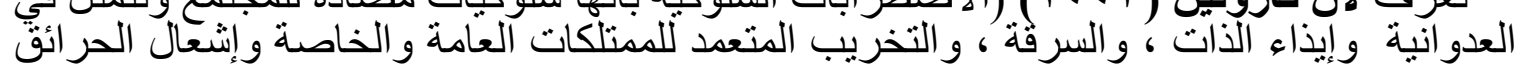


و هي سلوكيات تخرق القو اعد الاجتماعية ونوقعات الآخرين ولا تُمثلها)(لآن كازونين ترجمة محمد

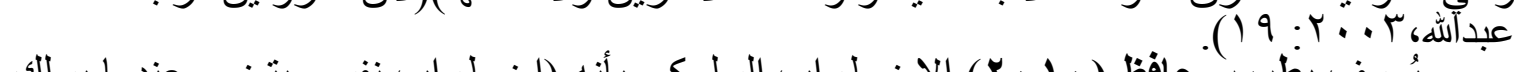

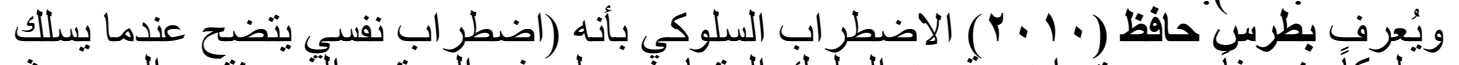

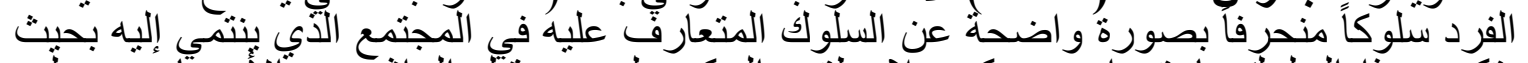

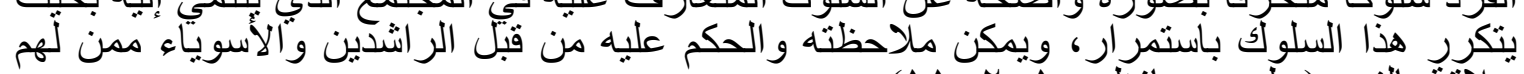

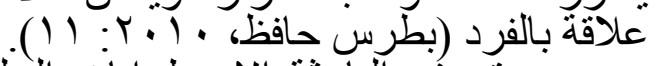

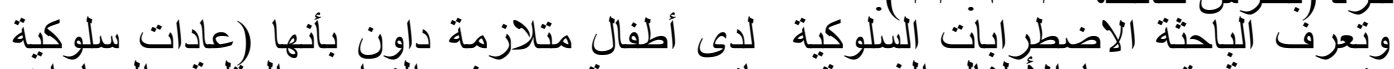

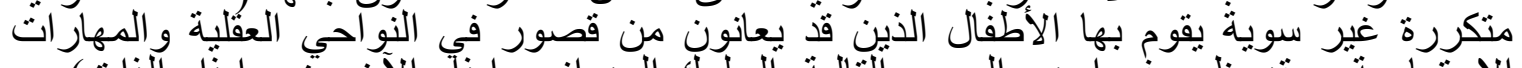

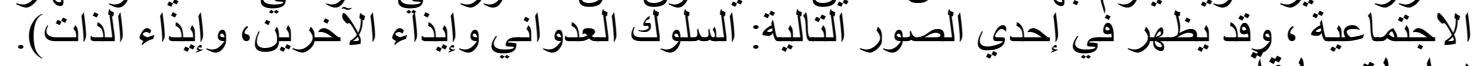
در اسات سياتة الابة

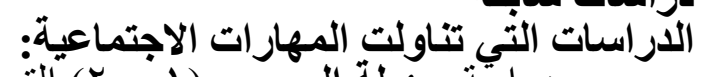

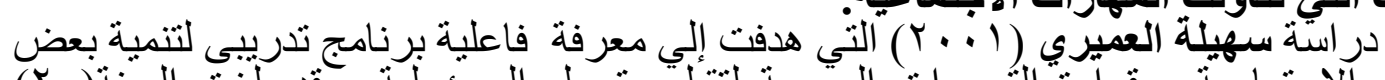

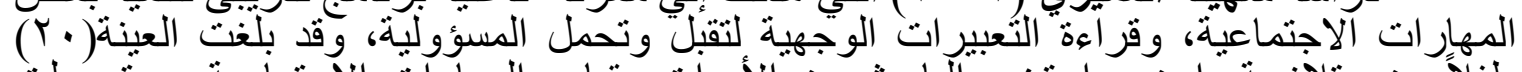

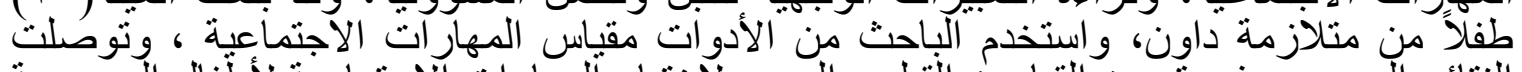

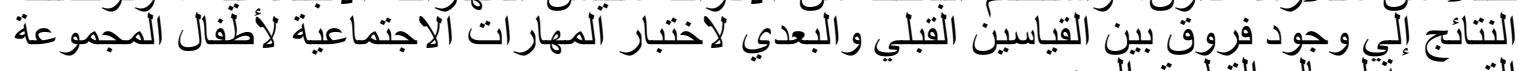

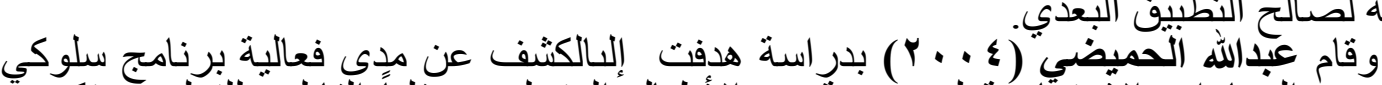

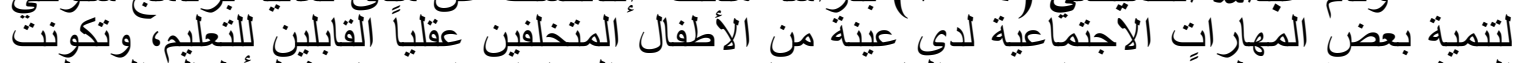

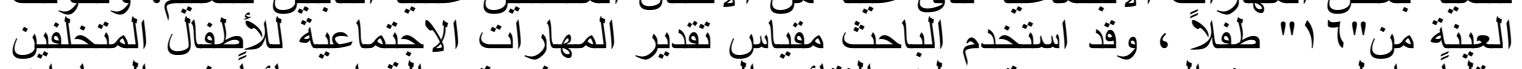

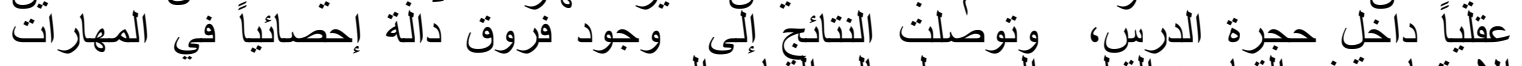

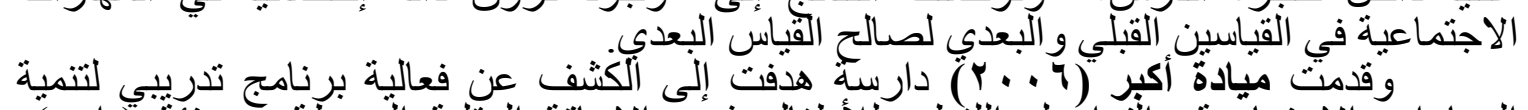

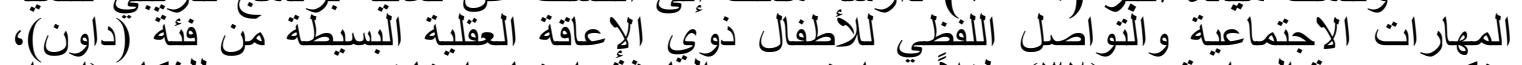

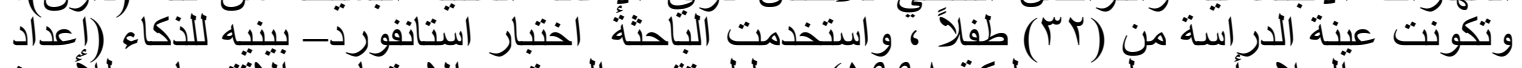

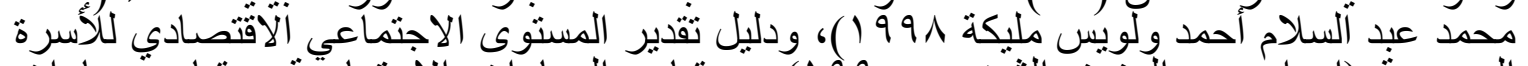

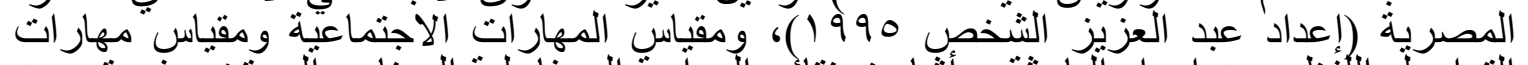

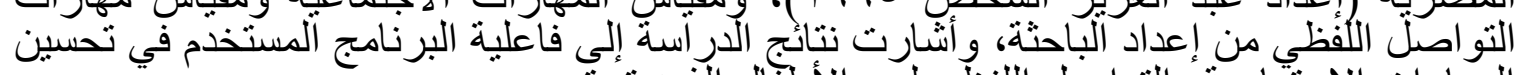

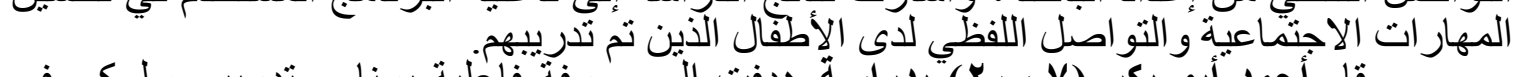

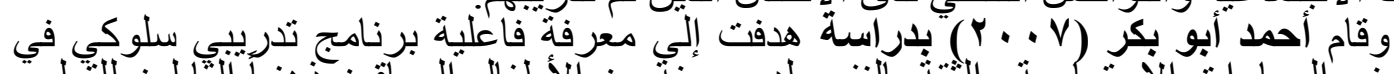

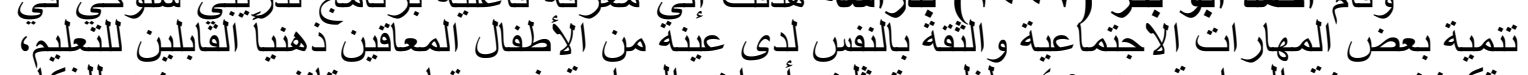

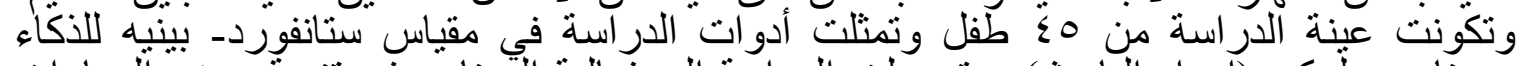

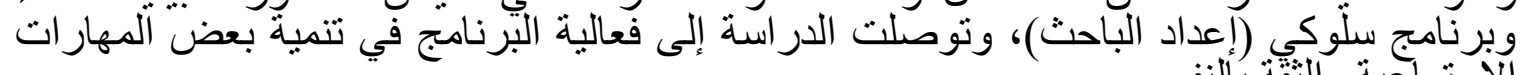

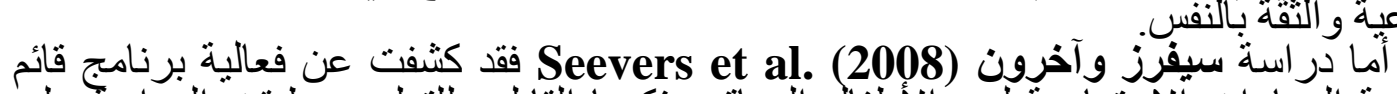

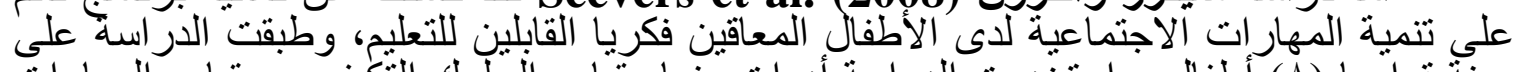

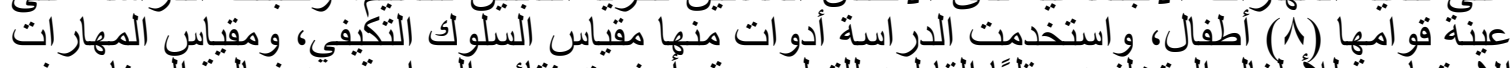

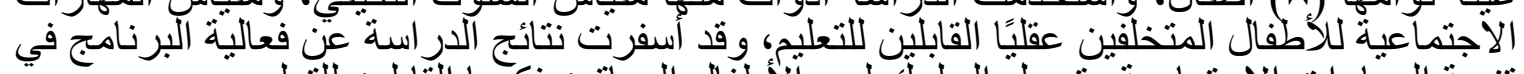

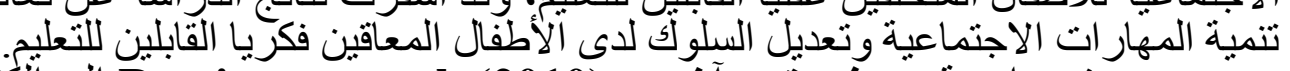

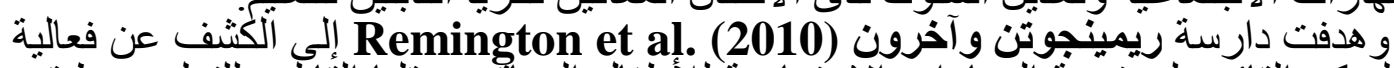

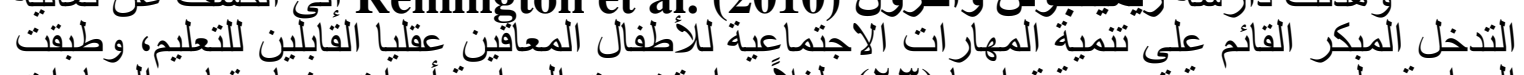

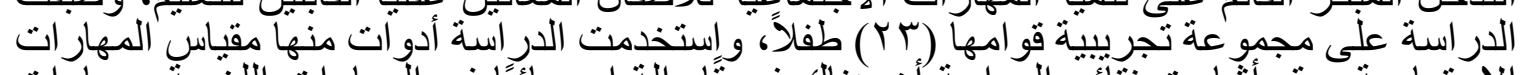

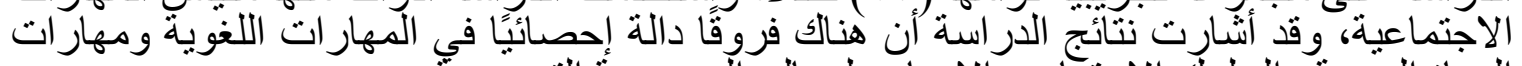

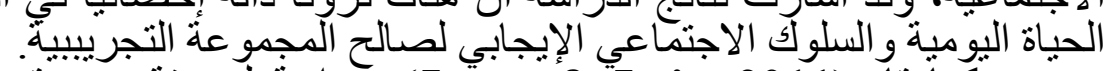

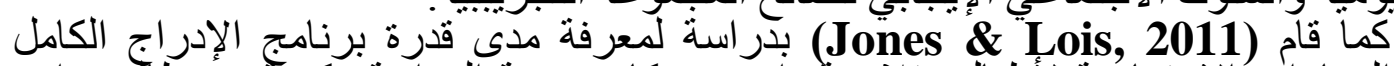

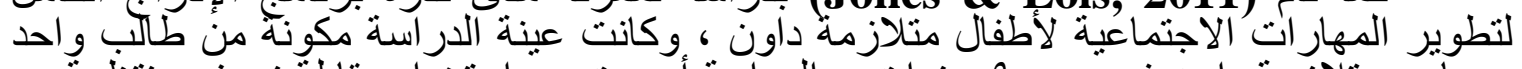

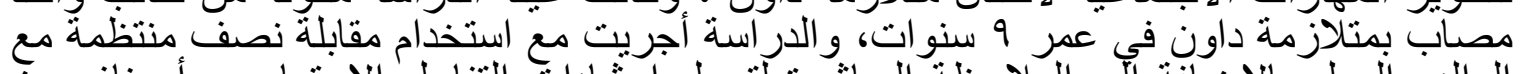

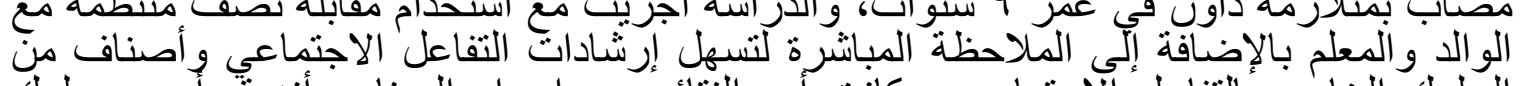

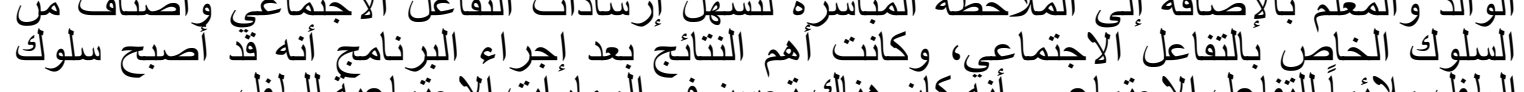

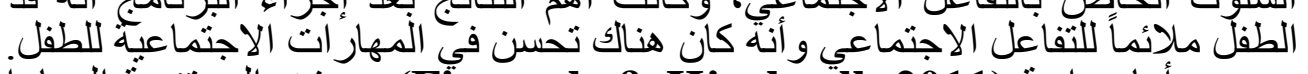

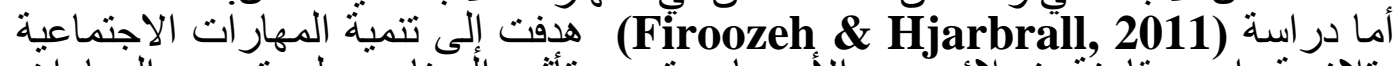

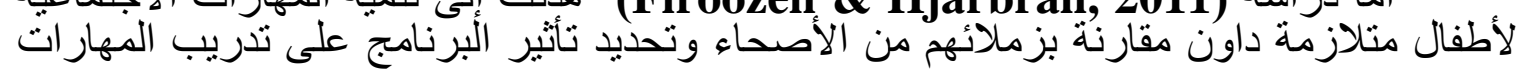




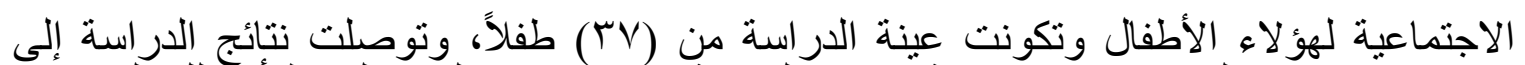

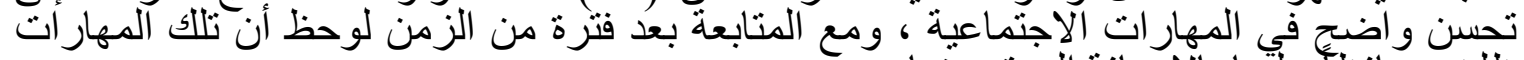

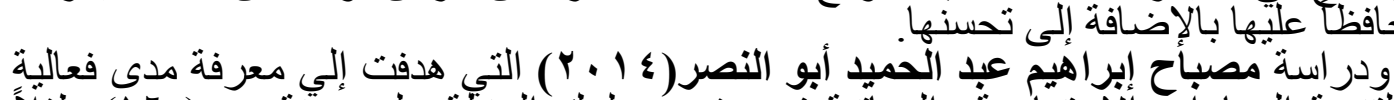

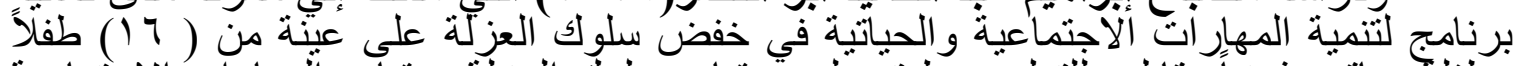

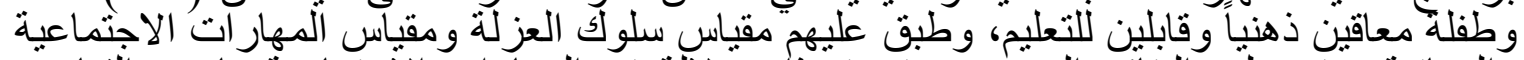

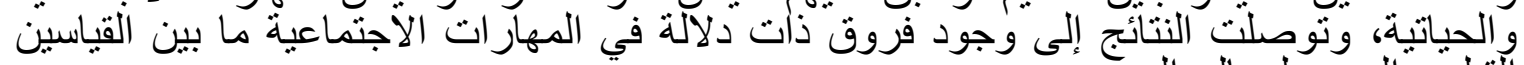

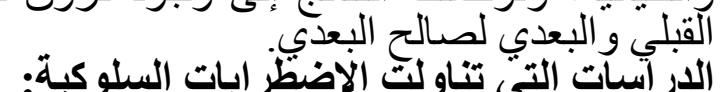

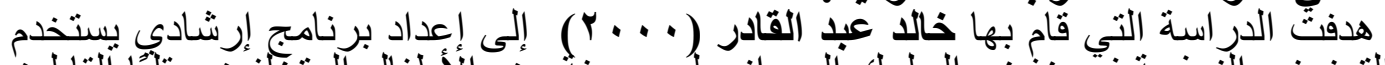

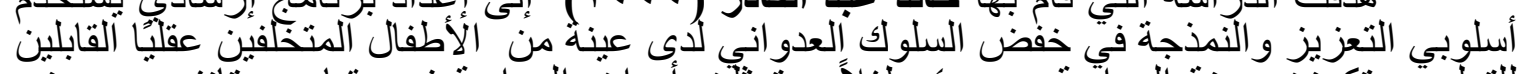

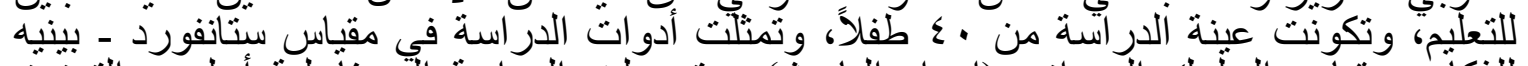

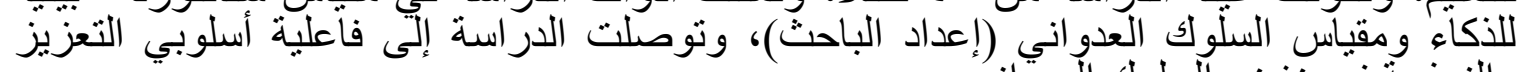

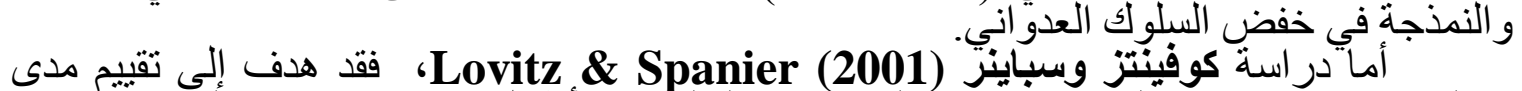

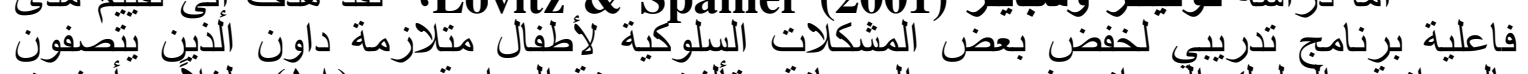

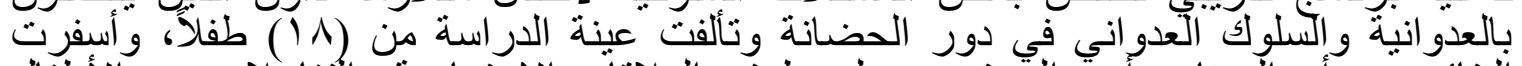

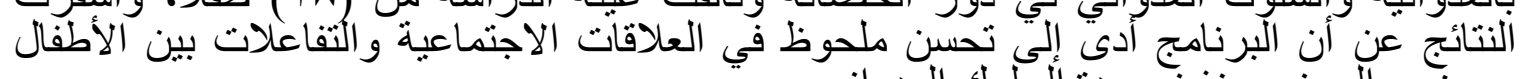

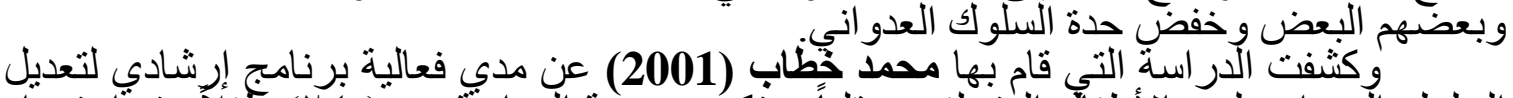

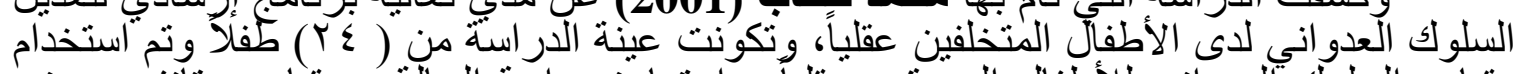

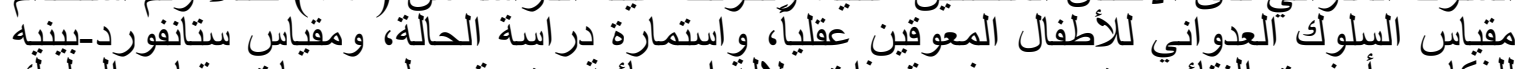

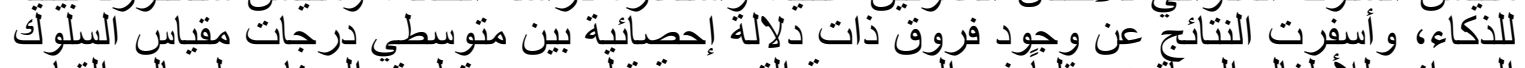

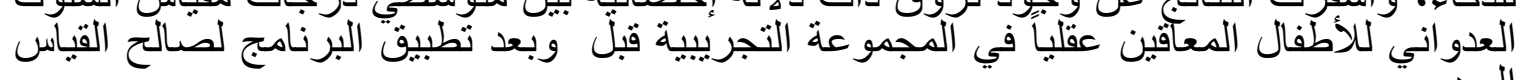

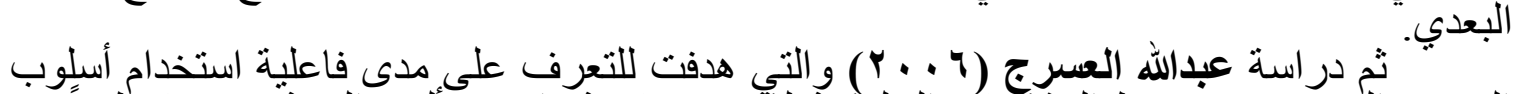

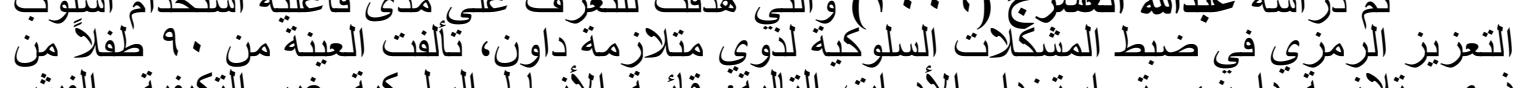

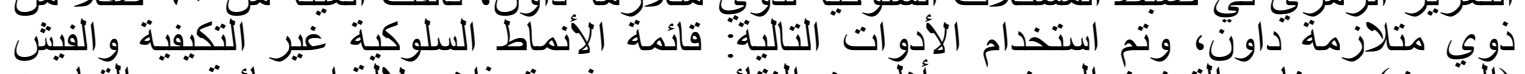

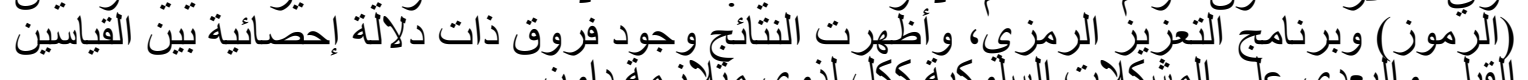

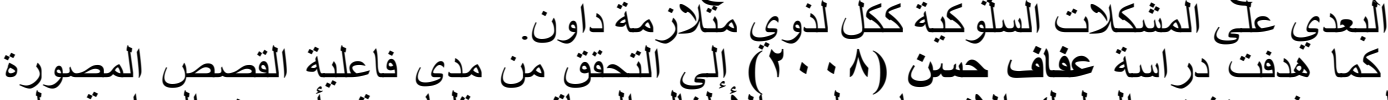

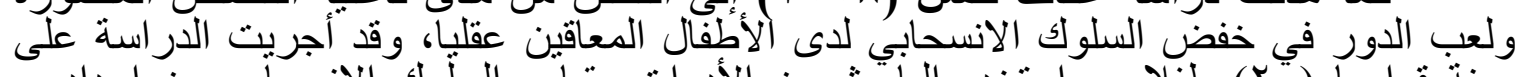

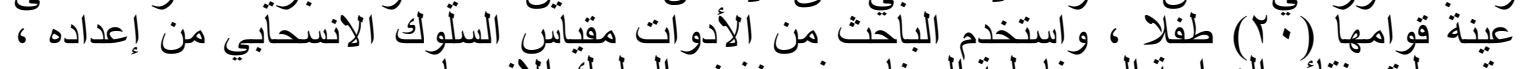

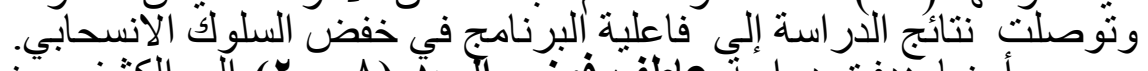

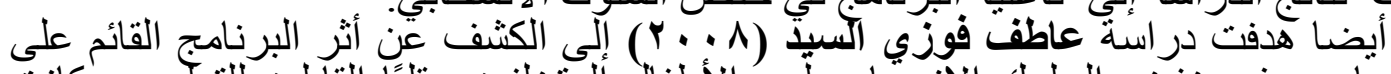

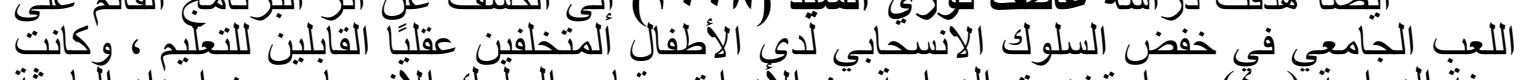

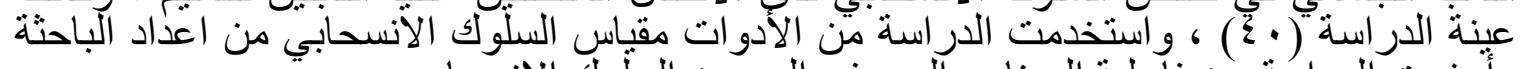

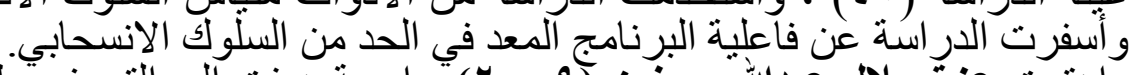

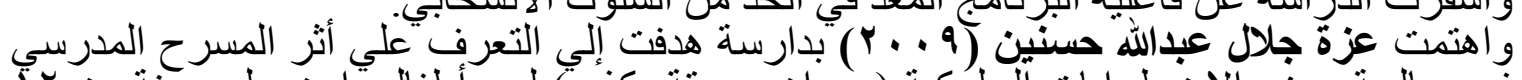

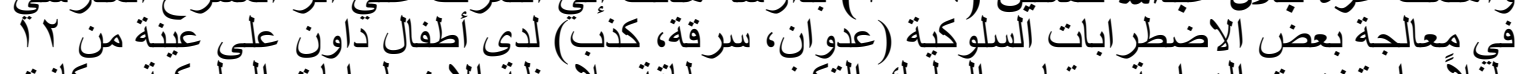

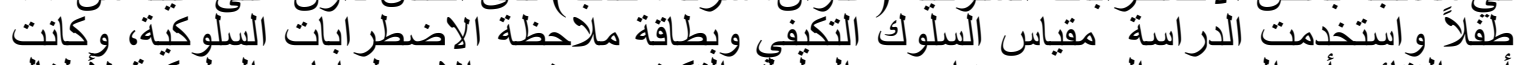

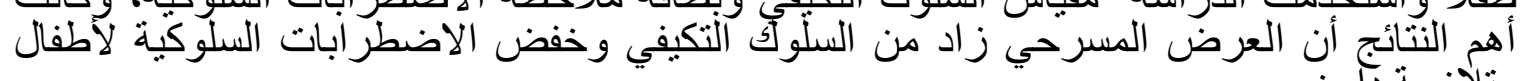

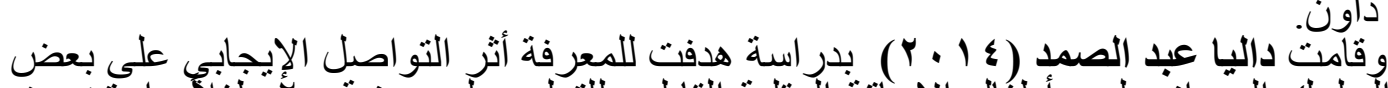
متلخز مة دأون.

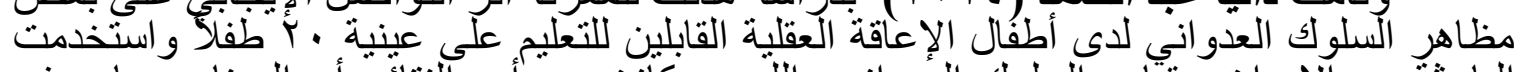

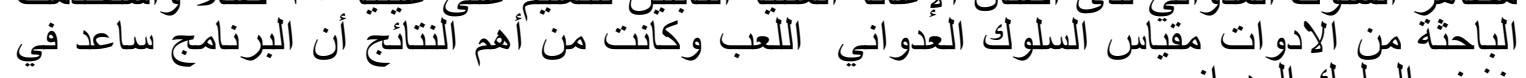

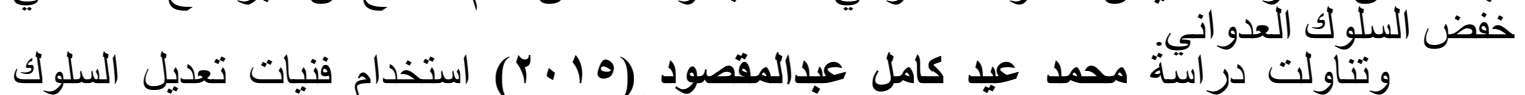

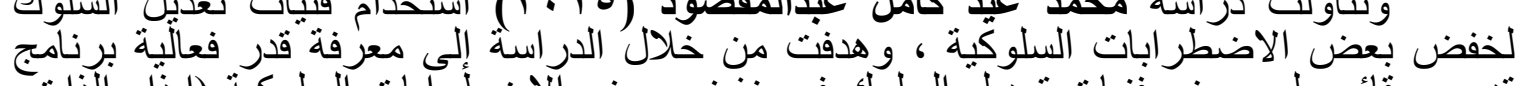

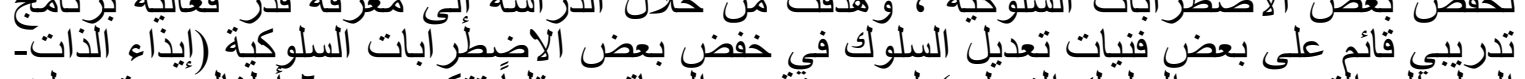

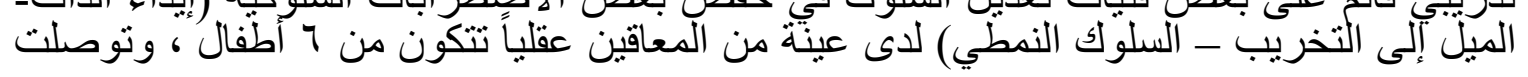


ألدرادة إلبي فاعلية البرنامج التدريبي لتعديل السلوك إلى خفض تلك الاضطر ابات السولكية لدى

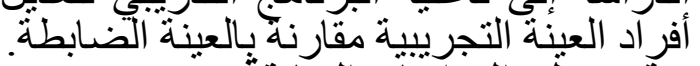
تعقيب على الدراستات السابقة:

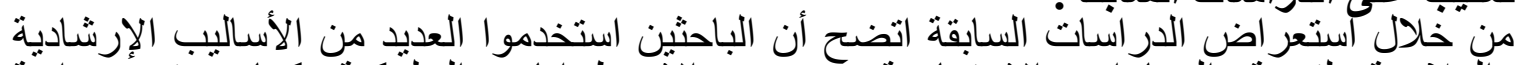

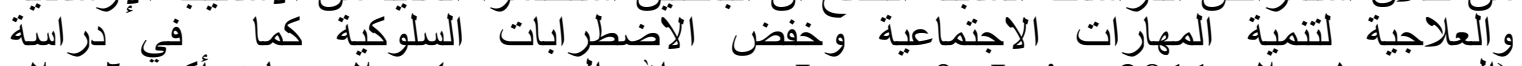
(العميري، ال . Jones \& Lois, 2011; ) ؛ Firoozeh \& Hjarbrall, 2011 ; Remington et al. ,2010; Seevers et al., 2008;

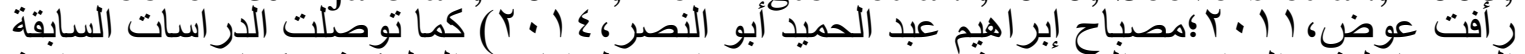

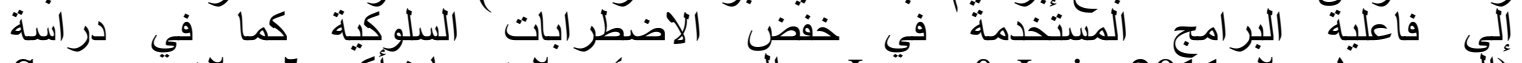

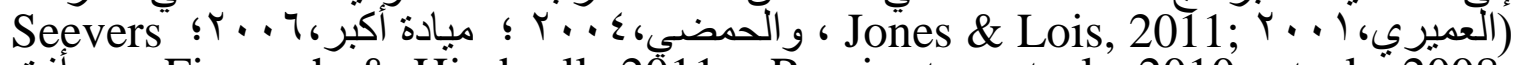
رأفت ; Firoozeh \& Hjarbrall, 2011 ; Remington et al. ,2010; et al., 2008;

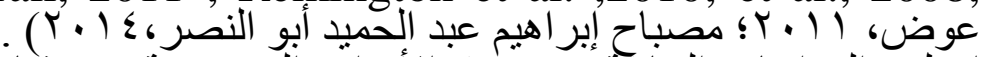

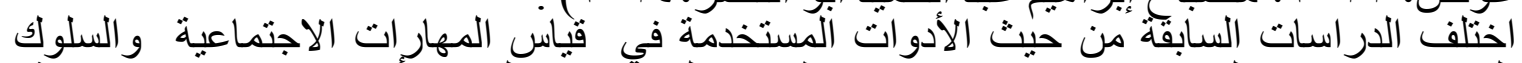

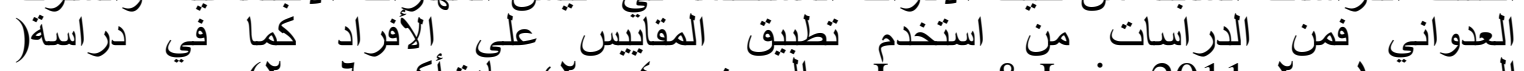

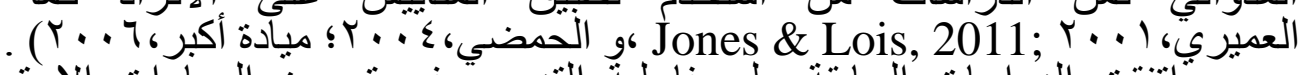

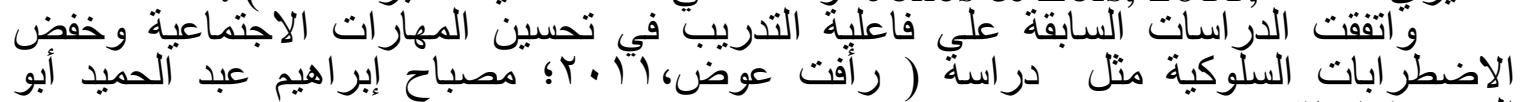

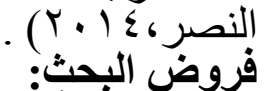

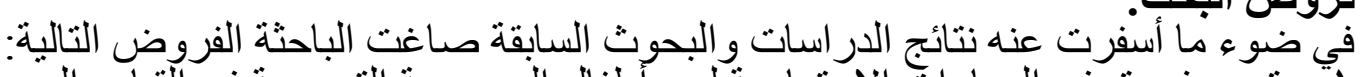

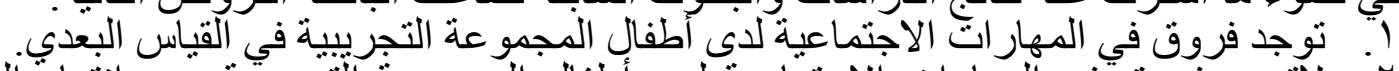

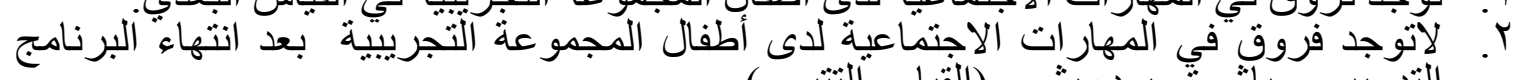

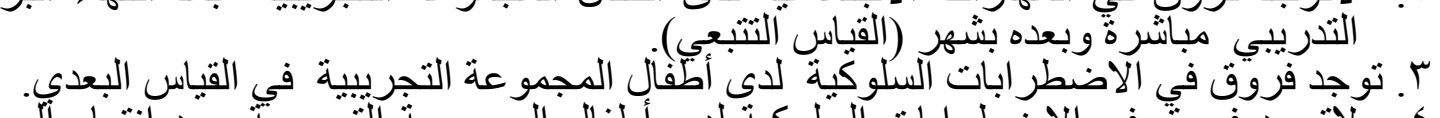

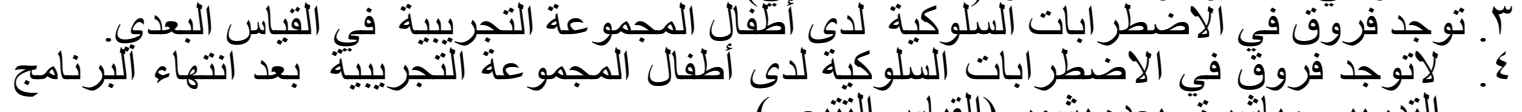
التذريبي مباشرة وبعده بشهر الاضطرابات (القياس التثبعي).

أولاج: منهج ألبحث:

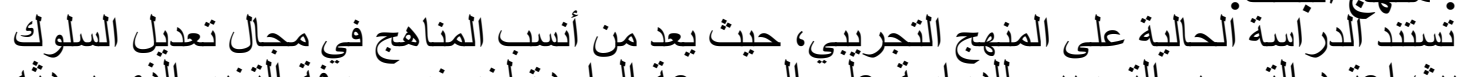

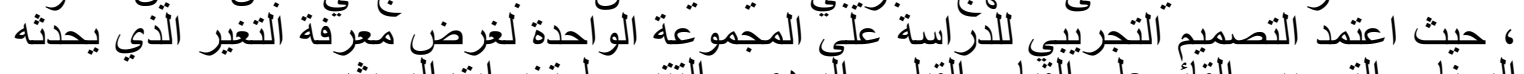

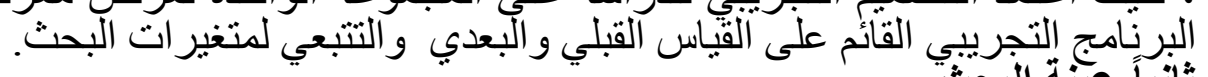

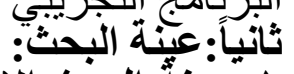

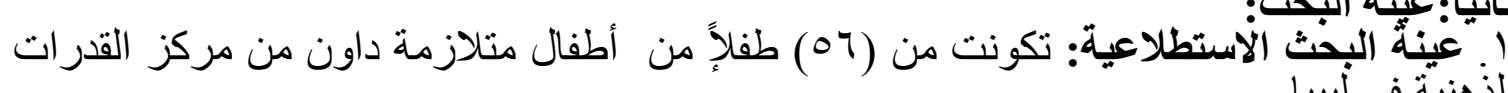

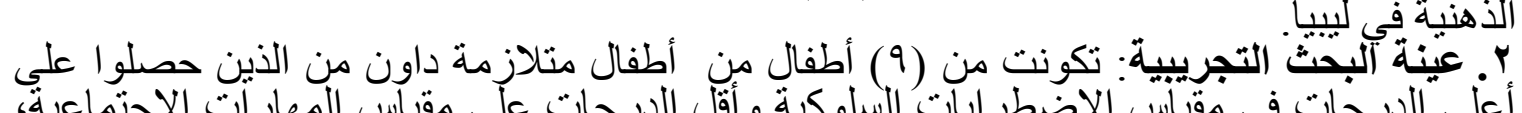

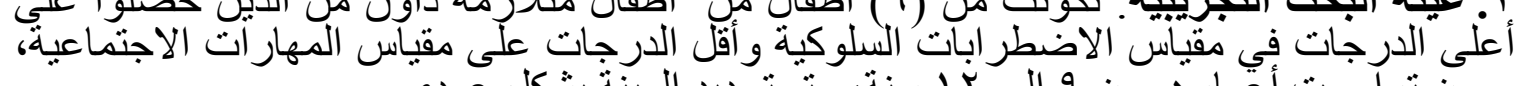

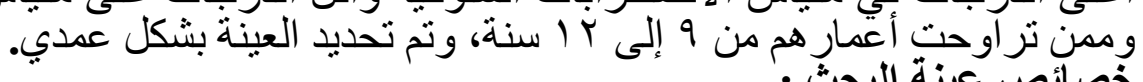

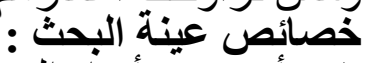

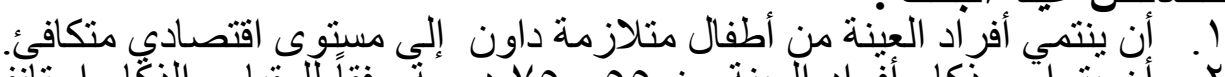

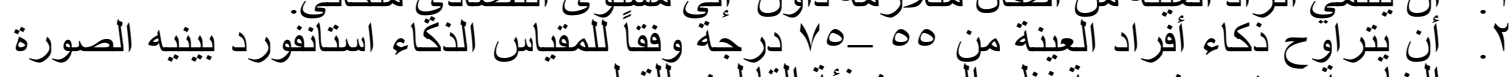

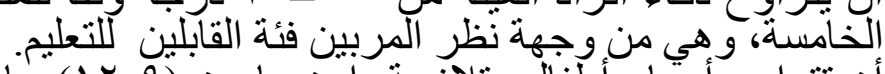

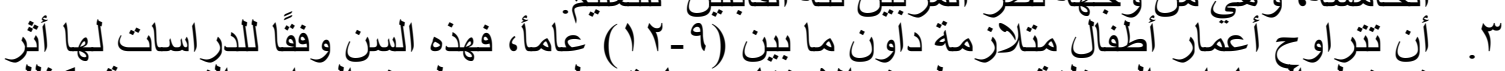

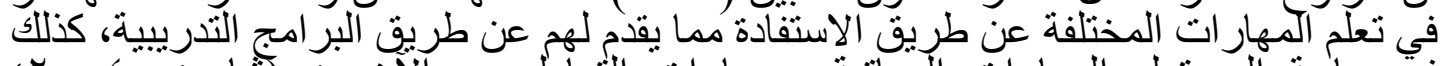

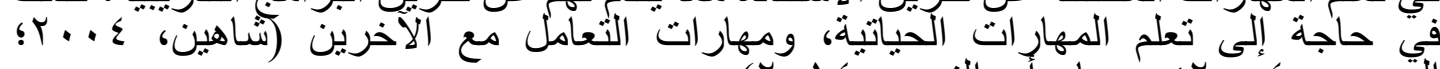

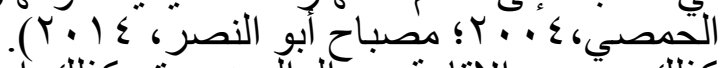

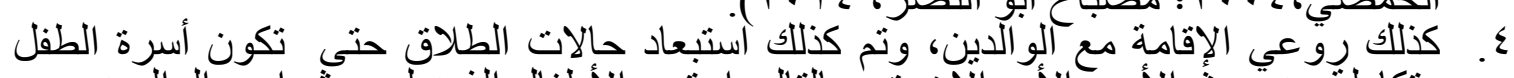

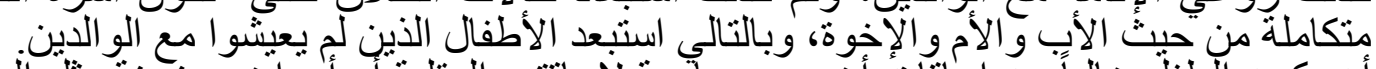

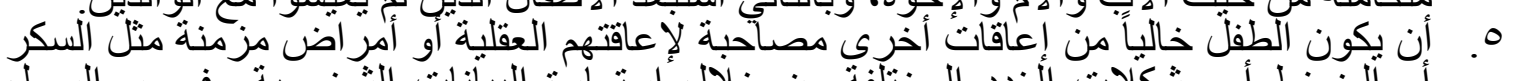

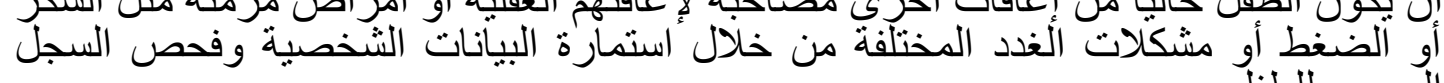
الصحي للطفل. 


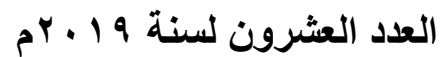

$\wedge 1 \wedge$

$$
\text { مجلة البحث العلمى فى التربية }
$$

T. أن تكون أسرة الطفل غير نازحة من منطقة إلى أخرى تبعًا للظروف السياسية وظروف

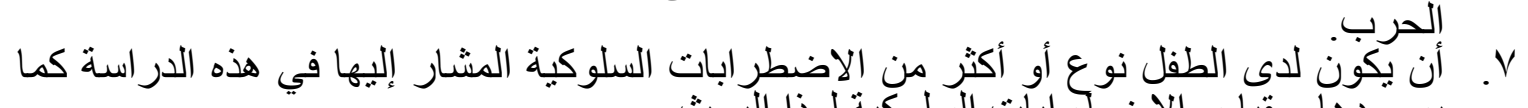

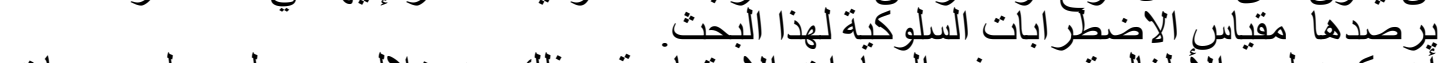

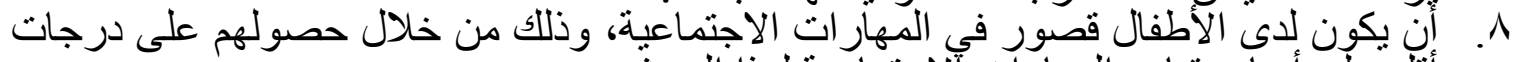

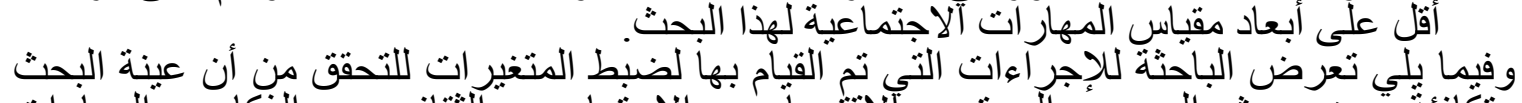

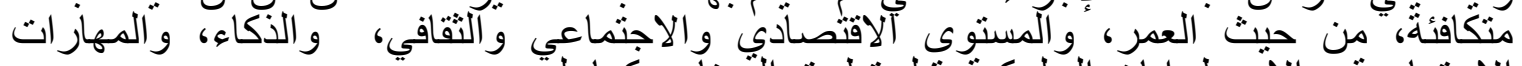

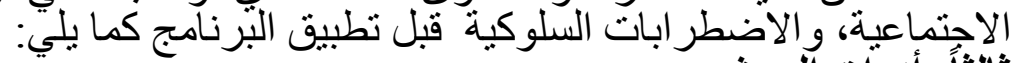
ثالثاً: أدوات البحثة

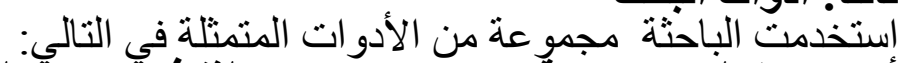

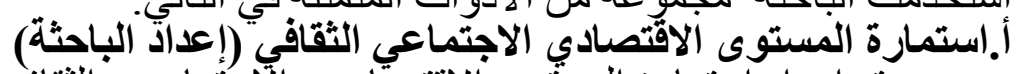

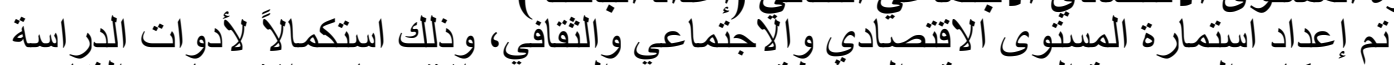

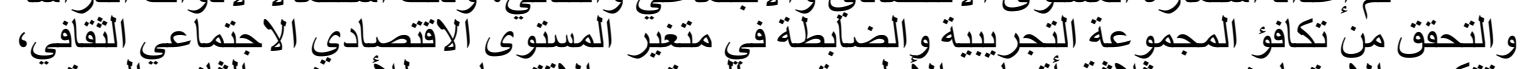

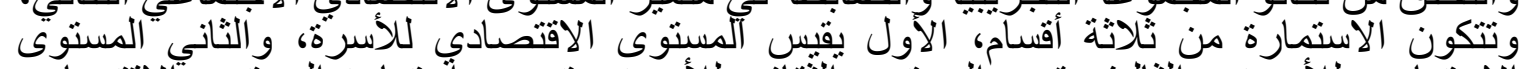

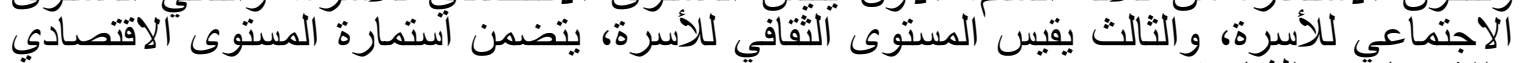

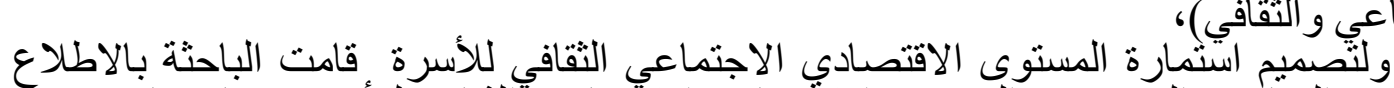

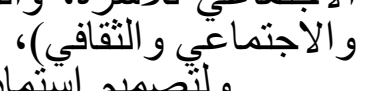

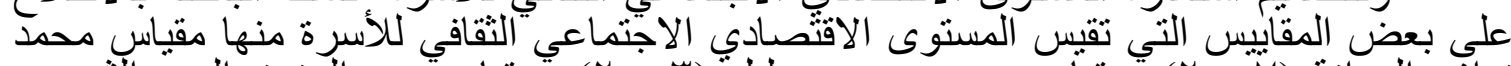

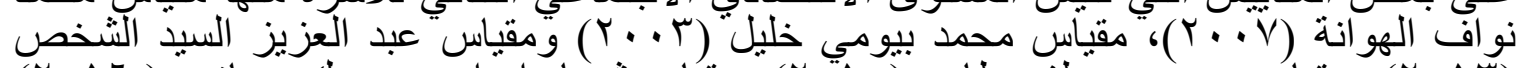

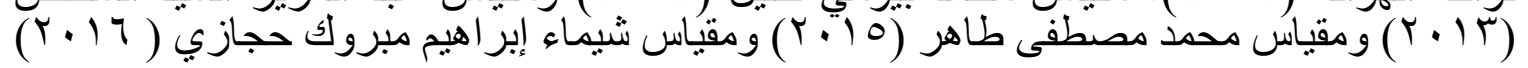

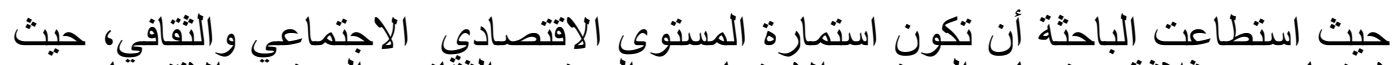

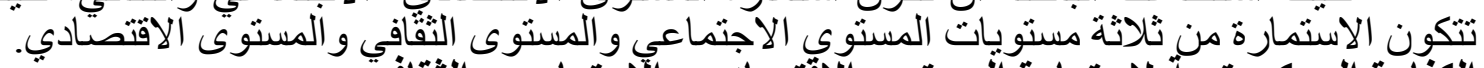

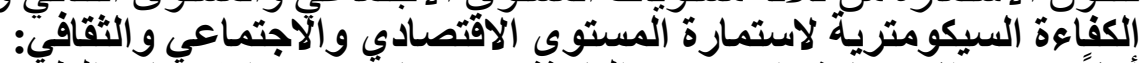

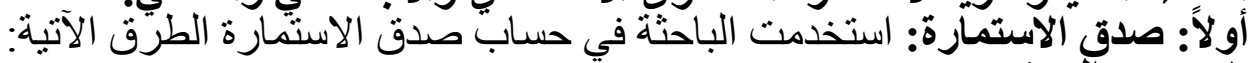

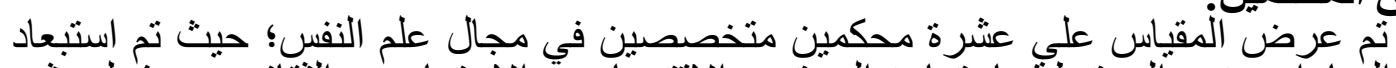

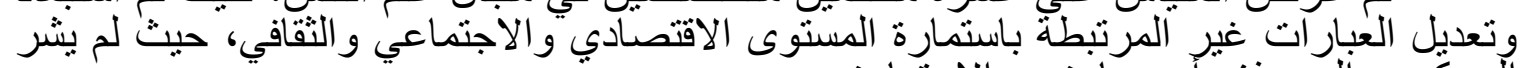

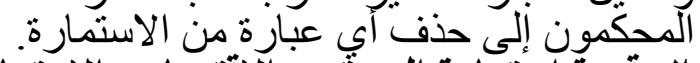

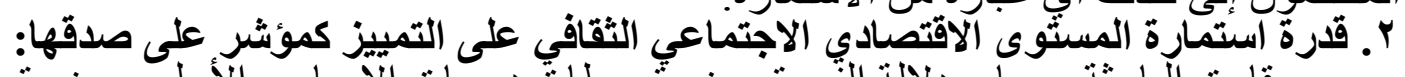

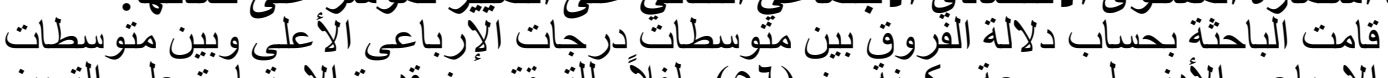

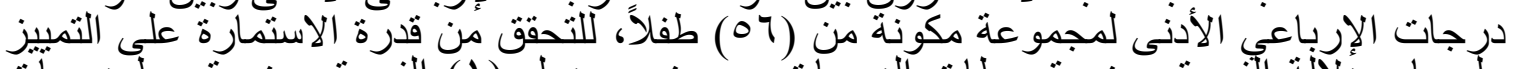

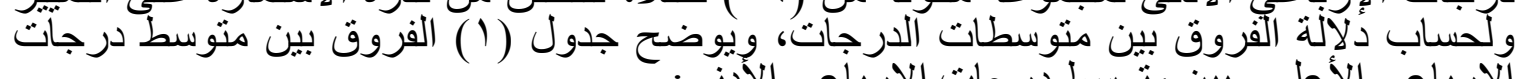

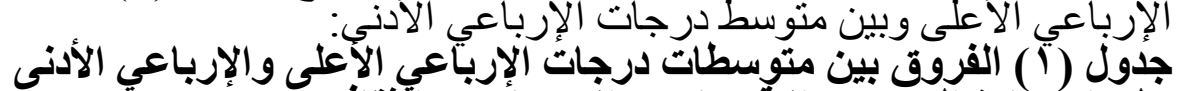

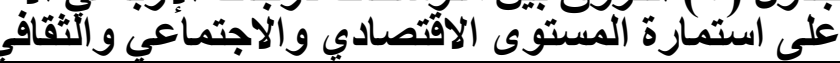

\begin{tabular}{|c|c|c|c|c|c|c|}
\hline الإحصائية & فيمه ت & الالمعياري & الحستوسطي & ن & والإزبنى & \\
\hline دال عند & $11>0$ & $\varepsilon, 0$. & To,7ह & TE & الإرباعي الادنى & \\
\hline & $11,1 \cdot 0$ & T,YA & Or.OV & TE & الإرباعي الاعلى & \\
\hline
\end{tabular}

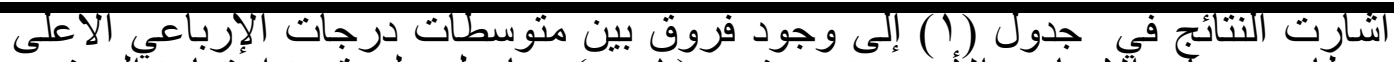

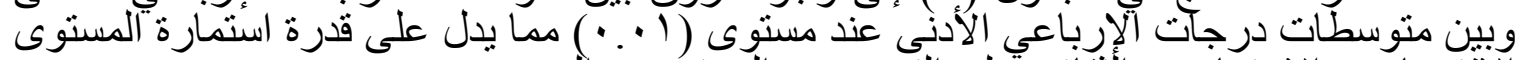

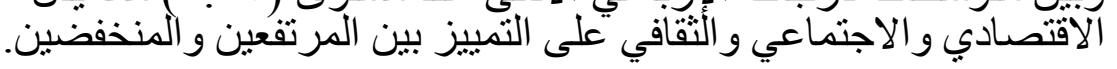
حساب ثبات استمارة المستوى الاقتصادي والاجتماعي والثقافي: 
تم تقدير ثبات استمارة المستوى الاقتصادي و الاجتماعي و الثقافي باستخدام معامل ألفاً

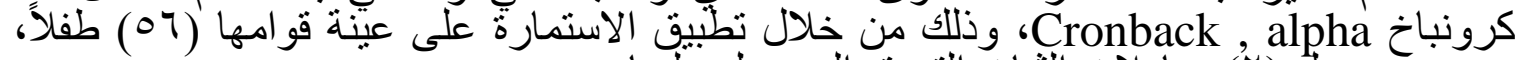

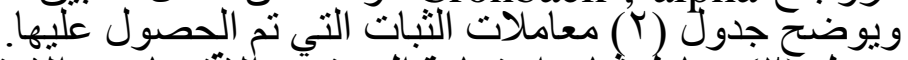

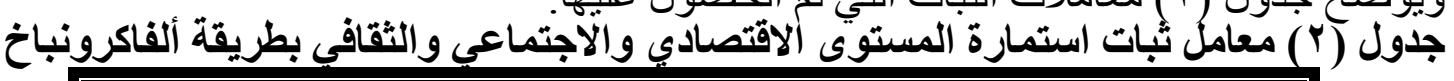

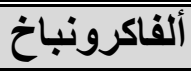

$$
\text { والاجتماعي والثقافئي }
$$

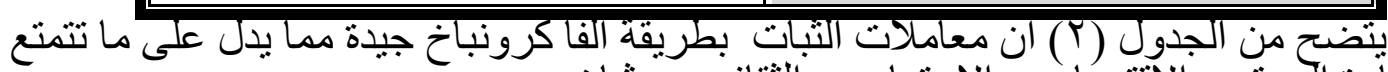

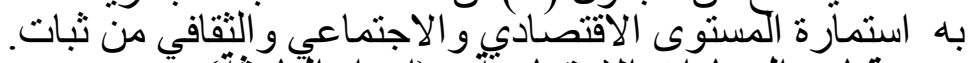

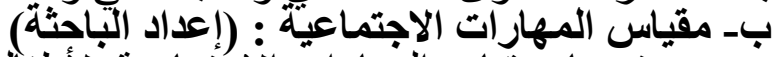

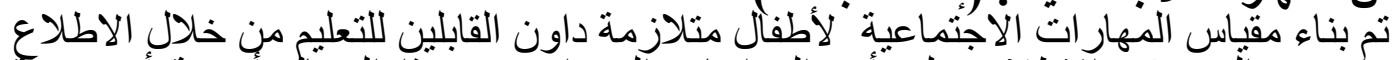

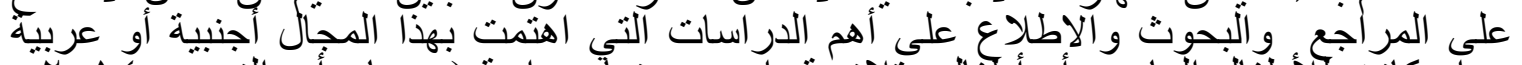

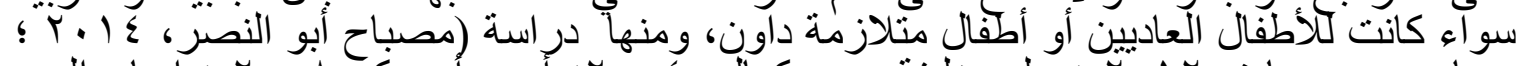

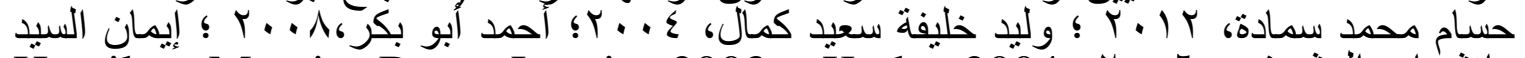

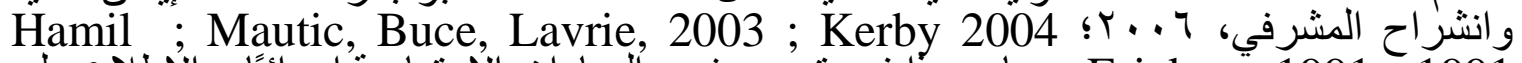
Erickson 1991 ; 1991

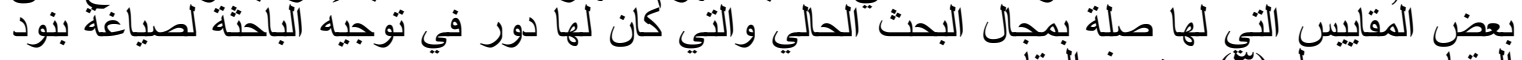

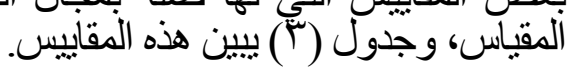

جدول (r) المقاييس التي تم الاطلاع عليها في تصميم مقياس المهارات الاجتماعية

\begin{tabular}{|c|c|c|c|}
\hline عدد العبارات & مكــــــــــــــات المقياس & اسم المقياس & المعد \\
\hline ET & 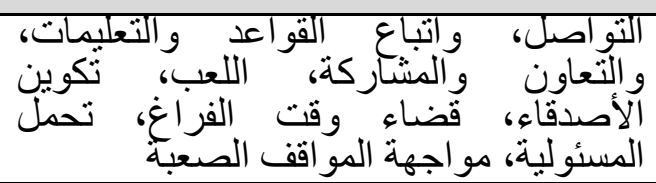 & المقياست الاجتماعية & 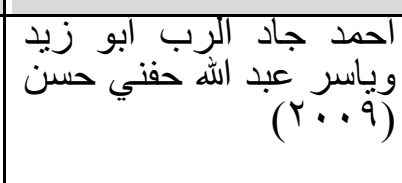 \\
\hline$\xi$ & 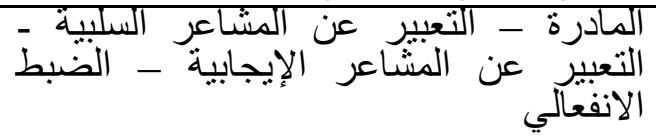 & 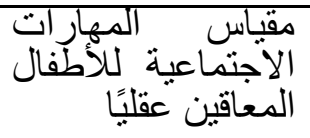 & خطاب، (رافت عوض) سعيد \\
\hline$\sum 1$ & 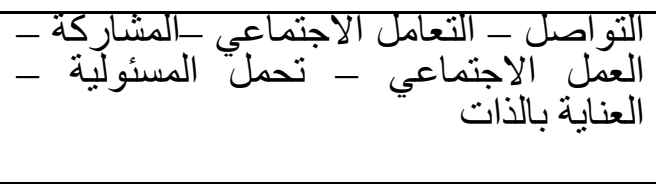 & 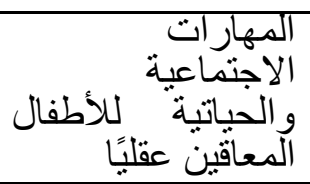 & (ع أ.باح إبراهيم ابو النصر \\
\hline$\pi$ & ------ & الاجتهاراتية للأطفال & 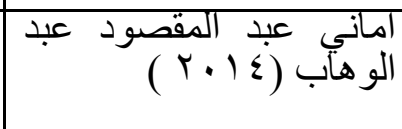 \\
\hline r. & التعاون - المشاركة ـ التخاطب & 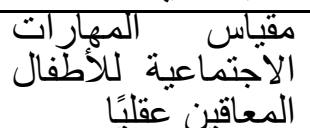 & 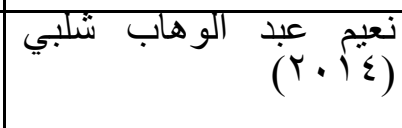 \\
\hline$\varepsilon v$ & 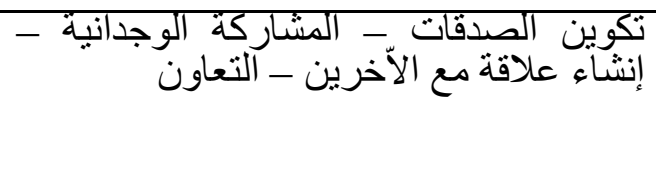 & 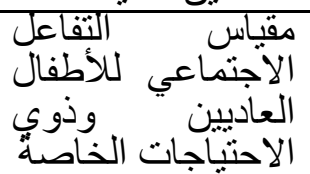 & 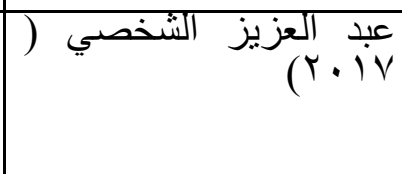 \\
\hline
\end{tabular}

توصلت الباحناة في ضوء الخطوات السابفه إلى تصميم مقياس المهارات الاجتماعية ليتضمن مهار ات: اــ التعامل مع الآخرين. بـ التو اصل و التخاطب و الحوار. بـ التعاون و المشاركة الاجتماعية.

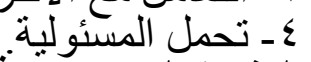

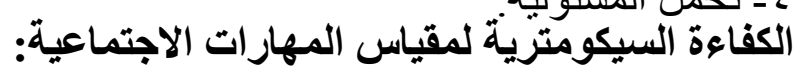




\section{العدد العشرون لسنة 9 1 م. بم \\ صدق المقياس: تم حساب صدق مقياس المهار ات الاجتماعية بطريقتين هما : مجلة البحث العلمى فى التربية}

Ar.

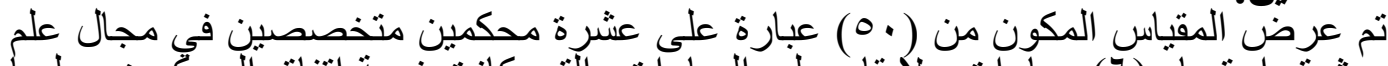

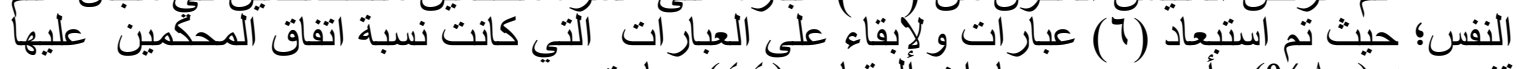

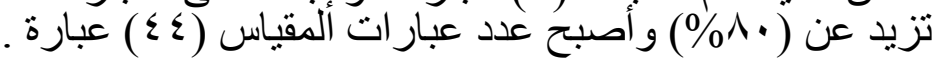

ب. قالبرة المقياس على التميزيز كمؤشر على صدقه:

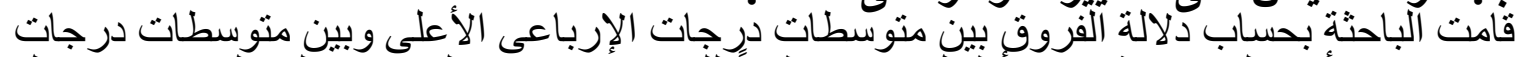

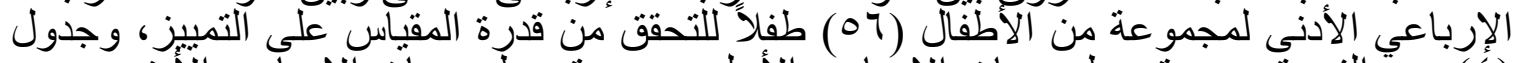

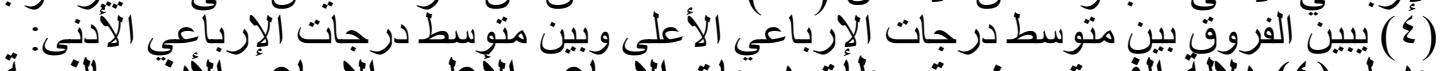

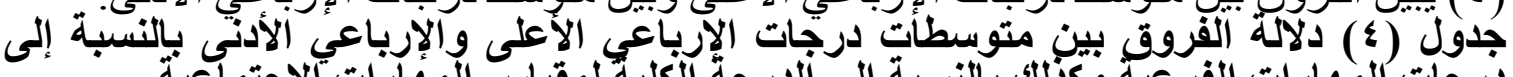

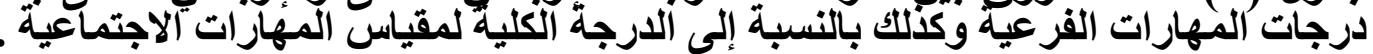

\begin{tabular}{|c|c|c|c|c|c|c|}
\hline الإحصائية & قيمة ت & الالنحرياري & الحستوسط & ن & الإرباعي الأعلى & المهار ات الاجتماعية \\
\hline \multirow{2}{*}{ 1ال ', عند } & \multirow[t]{2}{*}{ Tr, हरह } & .01 & $T, V O$ & TV & الإرباعي الادنى & \multirow{2}{*}{ التعامل مع الآخرين } \\
\hline & & T,VA & TE,TV & $T V$ & الإرباعي الاعلى & \\
\hline \multirow{2}{*}{ 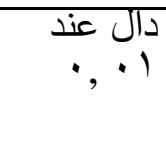 } & TY,VE. & TI & TY.OV & 19 & الإرباعي الادنى & \multirow{2}{*}{ التو اصل و التخاطب } \\
\hline & & $\varepsilon, \lambda 1$ & T7 & 19 & الإرباعي الاعلى & \\
\hline \multirow{2}{*}{ Iال عند } & \multirow[t]{2}{*}{$T \varepsilon, V R q$} & .01 & $1,7$. & 10 & الإرباعي الادنى & \multirow{2}{*}{ التعاون و المشاركة } \\
\hline & & $T, \varepsilon T$ & $11, \cdot 7$ & 10 & الإرباعي الاعلى & \\
\hline \multirow{2}{*}{ 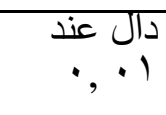 } & \multirow[t]{2}{*}{$T, 7 I V$} & .7. & $T M, T V$ & 19 & الإرباعي الادنى & \multirow{2}{*}{ تحمل المسئولية } \\
\hline & & r.qV & TO & 19 & الإرباعي الاعلى & \\
\hline \multirow{2}{*}{ دال ' , • } & \multirow[t]{2}{*}{ Tr, , } & T, rq & $\varepsilon q, 17$ & T. & الإرباعي الادنى & \multirow{2}{*}{ الدرجة الكلية } \\
\hline & & $1 T, 1$ & $19, \wedge 0$ & T. & الإرباعي الاعلى & \\
\hline
\end{tabular}

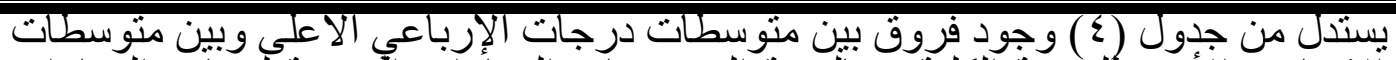

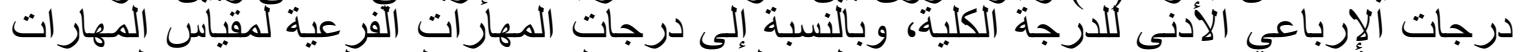

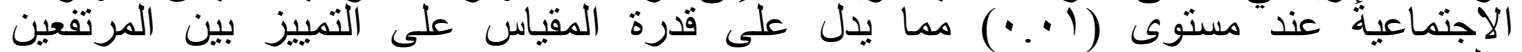

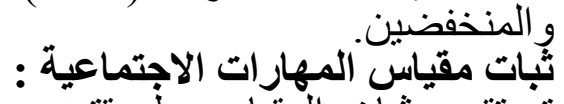

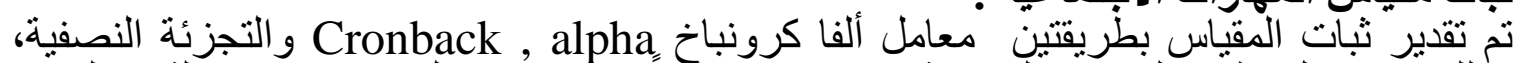

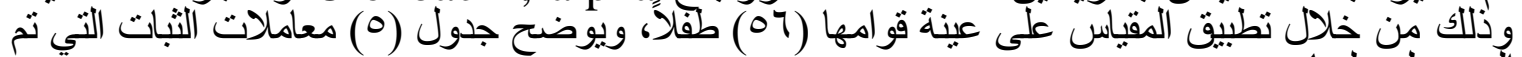
الحصول عليها. جدول (0) معاملات الثبات بطريقة ألفاكرونباخ والتجزئة النصفية

\begin{tabular}{|c|c|c|c|c|}
\hline التجزئه النصفية & الفاكرونباخ & عدد العبارات & المهارات الاجتماعيلة & 5 \\
\hline.$V V T$ & .879 & IT & التعامل مـع الاخرينن & 1 \\
\hline.$V A 1$ & 87 & TT & التو اصل والتخاطب & T \\
\hline.$\Lambda V V$ & VAT & $\lambda$ & اللتعاون والمشّاركة & $\Gamma$ \\
\hline$. \wedge \leqslant 7$ & . $A T$ & TT & تحمل المسئوليه & $\xi$ \\
\hline $.1 V^{\prime} T$ & $. \wedge \leqslant Y$ & $\varepsilon \varepsilon$ & يحه الكلية & \\
\hline
\end{tabular}

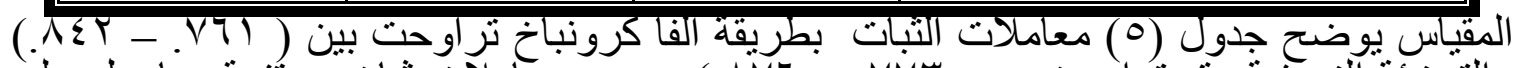

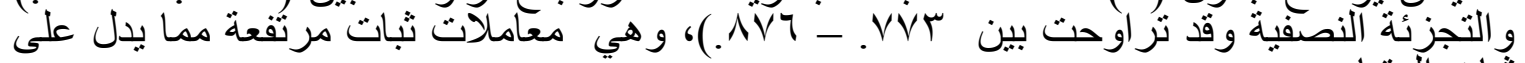

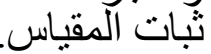
الصورة ألنهائية لمقياس المهارات الاجتماعية: 


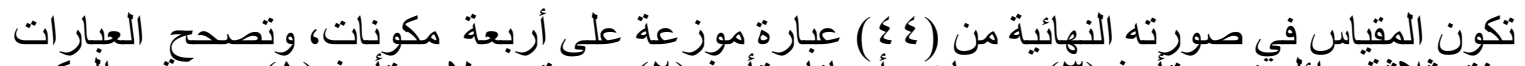

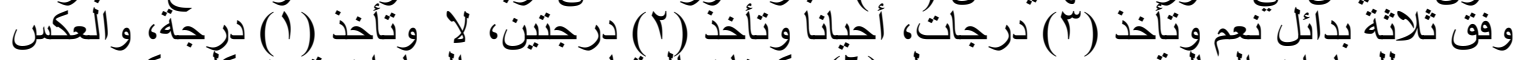

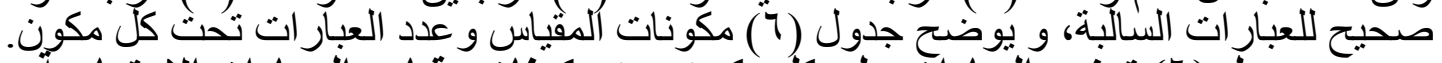

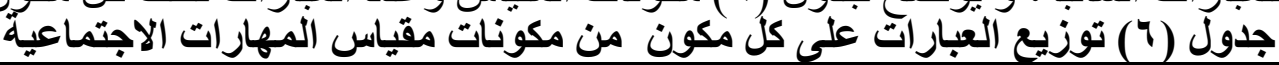

\begin{tabular}{|c|c|c|c|c|}
\hline البعد $\quad$ عبارات & العبارات الموجبه & العبارات السالبه & الاجتماراتية & م \\
\hline T' عبارة & $\left.T Y_{-} \mid I_{-} q_{-} \Lambda_{-} V_{-} \tau_{-} o_{-} \varepsilon_{-} r_{-} r_{-}\right)$ & T. & التعامل مع الاخرين & $T$ \\
\hline T ا عبارة & $V_{-} \tau_{-} \varepsilon_{-} r$ & $-11-1 \cdot-q_{-} \Lambda_{-} 0_{-} T_{-1}$ & التو اصل والتخاطب & T \\
\hline ᄉ عبار ات & $\lambda_{-} V_{-} 0_{-} \varepsilon$ & $\left.\tau_{-} r_{-} r_{-}\right)$ & التعاون والمشّاركة & r \\
\hline T ا I عبارة & $1 \cdot a^{-} \Lambda_{-} \theta_{-} \varepsilon_{-} r^{-} t$ & $\left.\left|Y_{-}\right| I_{-} V_{-}\right)_{-} T$ & تحمل المسئولية & $\varepsilon$ \\
\hline ع ع عبارة & T7 & 11 & المجموع الموع & \\
\hline
\end{tabular}

ج. مقياس الاضطرابات السلوكيه (إعداد البإحتهة)

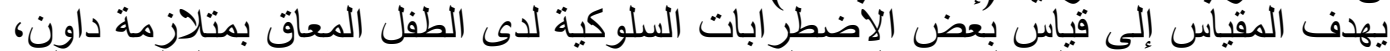

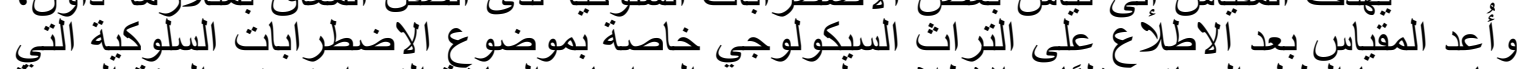

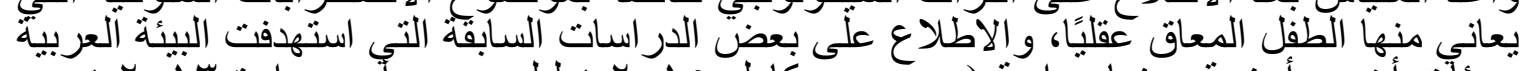

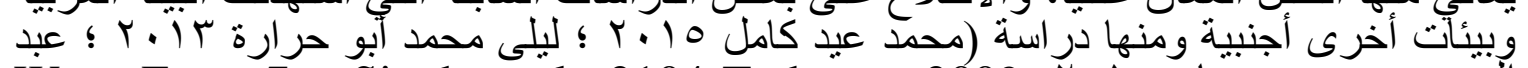

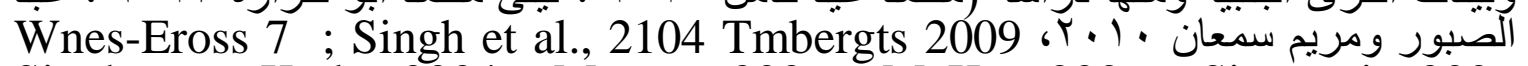
Singhect ; Kerby 2004; Matswn 2006 ; McKay 2006 ; Sinperstin 2006

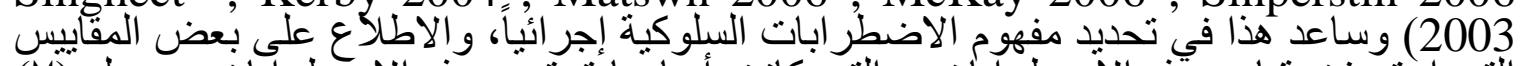

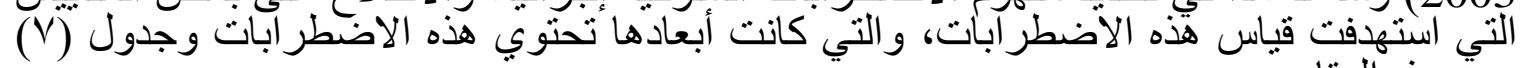

جدول (V) المقاييس التي تم الاستعانة بها في تصمير مقياس الاضطرابات السلوكية

\begin{tabular}{|c|c|c|c|}
\hline عدد العبار ات & لـــــــات المقياس & اسم المقياس & \\
\hline Tr & 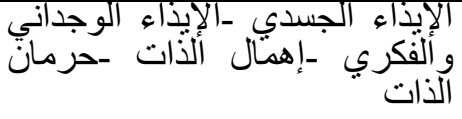 & 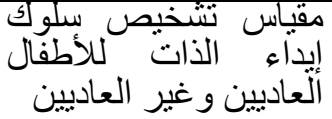 & 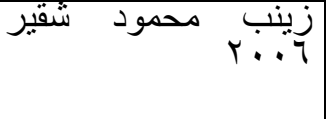 \\
\hline TY & العدوان اللفظي المادي - - العدائية - & 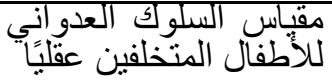 & أبو زيد · محمد جاب الرب الرب \\
\hline TT & 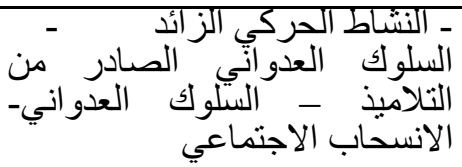 & 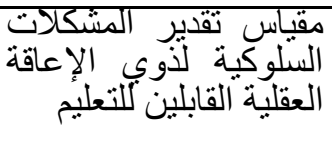 & 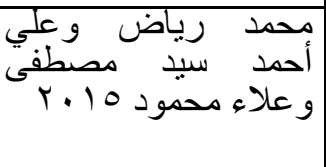 \\
\hline 97 & ـ العدائية العدواني المادي - واللفظي & 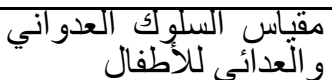 & امال عبد السميع اباظة \\
\hline VT & 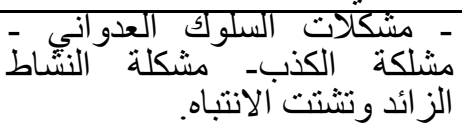 & مقياسية & الوهأب عبد المقصود عبد 10 مبد \\
\hline 70 & العدوانية - السلاقة - التمرد الهروب - الكذب- & السفئسية للأطفال المشكلات & نهمود ماد عبد الو هاب \\
\hline
\end{tabular}

ومن خلال المقاييس التي تم الاطلاع عليها تم التوصل إلى فلانة مكونات للاضطر ابات السلوكية

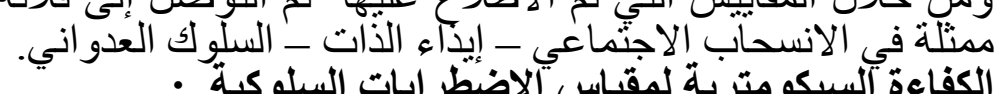

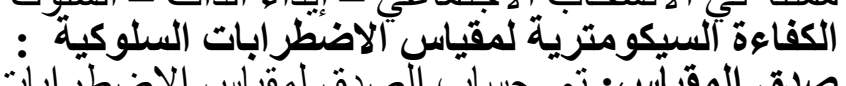

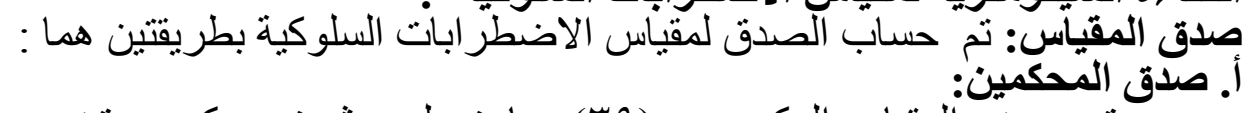

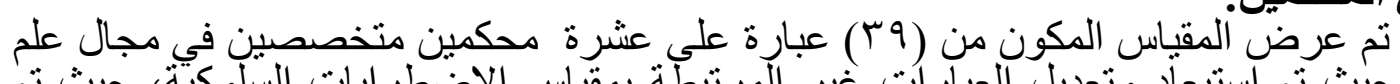

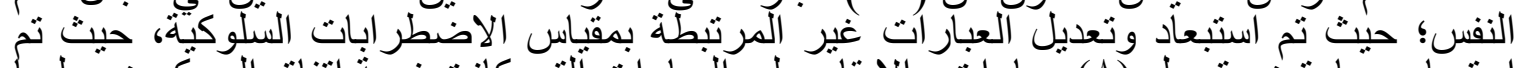

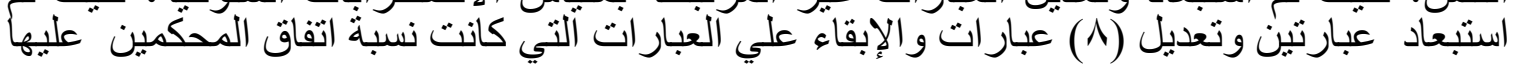




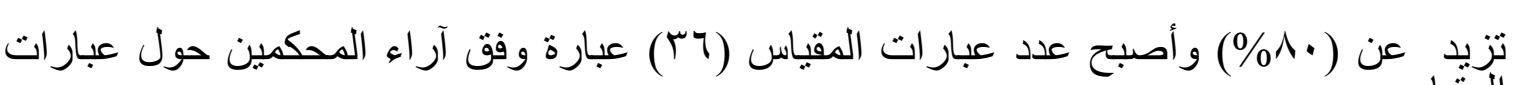
مجلة البحث العلى فى التربية

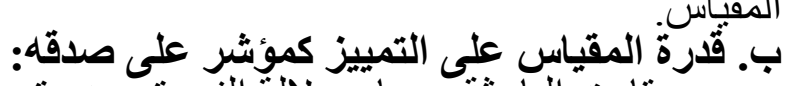

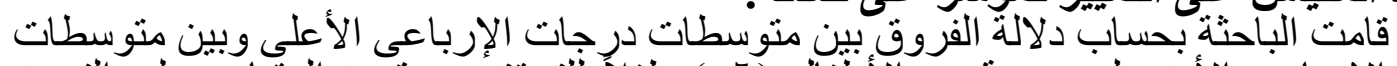

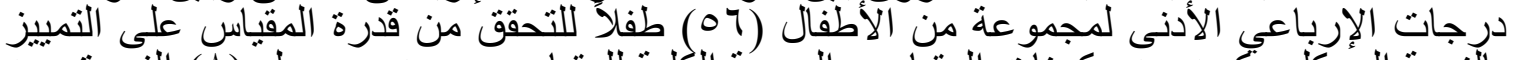

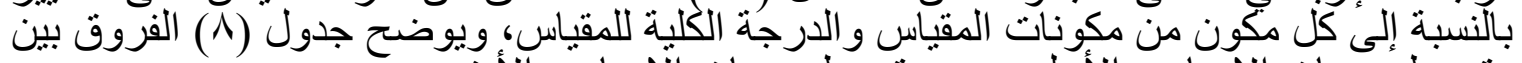
متوسط درجات الإرباعي الأعلى وبين متوسط درجات الإرباعي الأدنى:

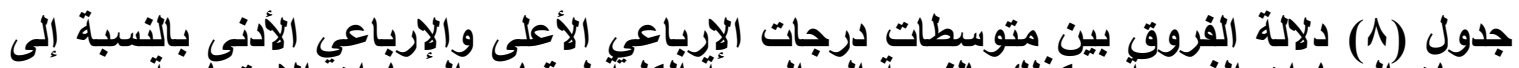

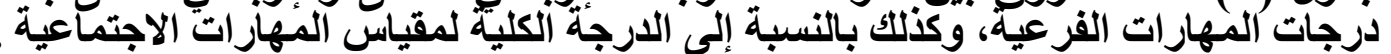

\begin{tabular}{|c|c|c|c|c|c|c|}
\hline |الإلالائية & قيمة ت & الالاتحرافي & الحستوسي & ن & والأإنياعي & الاضلوكية ابات \\
\hline \multirow{2}{*}{ 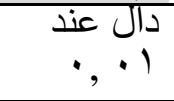 } & \multirow[t]{2}{*}{ 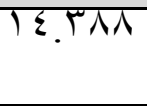 } & 1.1 & IT & 10 & الإرباعي الادنى & \multirow{2}{*}{ الالاجتماغي } \\
\hline & & $T, \wedge$. & $T, 1 T$ & 10 & الإرباعي الاعلى & \\
\hline \multirow{2}{*}{ 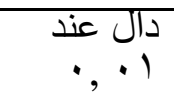 } & \multirow[t]{2}{*}{$\pi, 117$} & 1,75 & TE.Tा & 17 & الإرباعي الادنى & \multirow{2}{*}{ | إيذاء الذات } \\
\hline & & $\varepsilon, 19$ & $r v, \varepsilon 1$ & 17 & الإرباعي الاعلى & \\
\hline \multirow{2}{*}{ 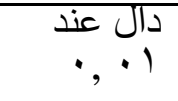 } & \multirow[t]{2}{*}{$T \leqslant, \Gamma \leqslant \varepsilon$} & $7, \mathrm{TV}$ & $17, \varepsilon \mathrm{V}$ & 10 & الإرباعي الادنى & \multirow{2}{*}{ السلوك العدواني } \\
\hline & & 1,11 & $r \wedge, 70$ & 10 & الإرباعي الاعلى & \\
\hline \multirow{2}{*}{ 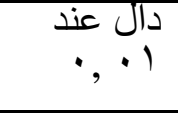 } & \multirow[t]{2}{*}{$1 \cdot, 599$} & 14,49 & EV,YY & 11 & الإرباعي الادنى & \multirow{2}{*}{ الدرجة الكلية } \\
\hline & & $\Lambda, \vee \cdot$ & $10, Y_{1}$ & 11 & الإرباعي الاعلى & \\
\hline
\end{tabular}

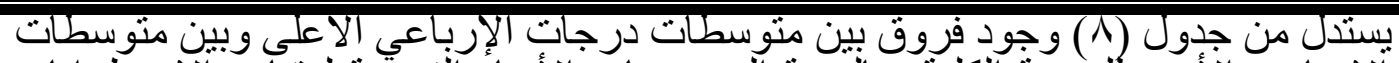

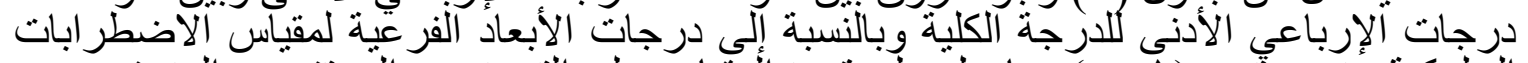

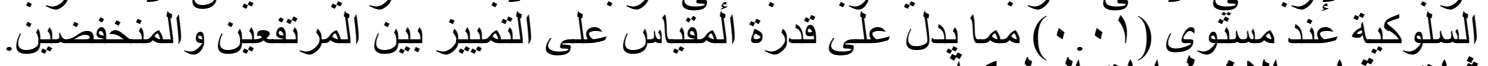
ثبات مقياس الاضطر ابات النئوكية :

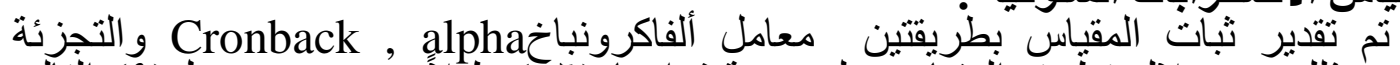

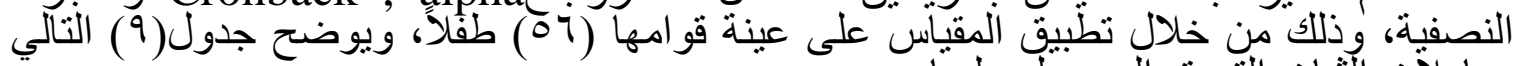

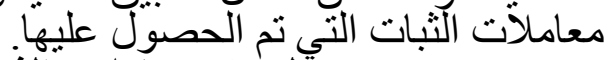

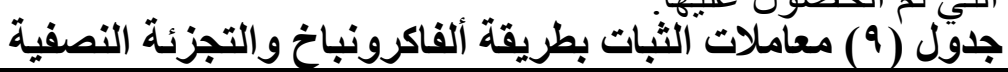

\begin{tabular}{|c|c|c|c|c|}
\hline آلتجزئه النصفيا & الفاكرونباخ & عدد العبارات & الاضطرابات السلوكيه & 2 \\
\hline . NTT & .117 & 1. & الأسحاب الاجتماعي & $\frac{1}{1}$ \\
\hline 101 & NY7 & TT & إيذاء الذأت & T \\
\hline$V 77$ & V01 & $1 \varepsilon$ & أُلْيلوك العدوأي & $\Gamma$ \\
\hline .10T & . 995 & T4 & الارجه الكلية & \\
\hline
\end{tabular}

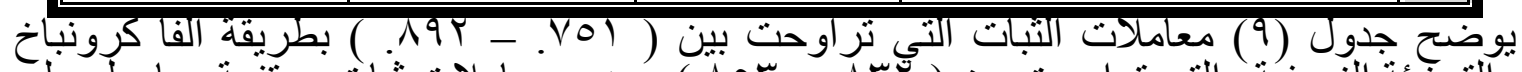

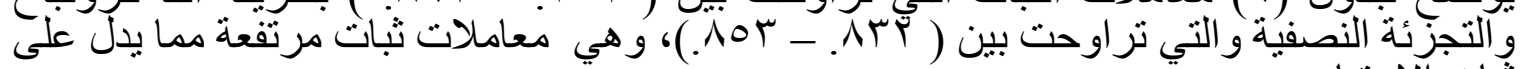

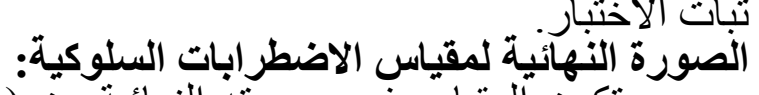

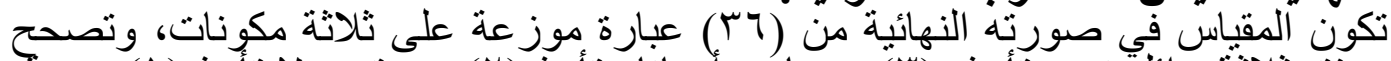

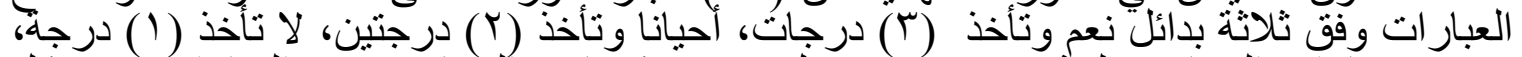
وجميع عبارات المقياس سلبية ، ويوضح جدول (· ·() مكونات المقياس و عدد العبارات تحت كل ألجدولوكية (· ) أرقام وتوزيع العبارات على كل مكون من مكونات مقياس الاضطرابات مكون.

\begin{tabular}{|c|c|c|}
\hline علد عبارات البعد & | ل العبارات & ابعاد مقياس الاضطر ابات السلوكيل \\
\hline • أ عبارات & $(1 \cdot-1)$ & الأنسحاب الاجتماعي \\
\hline S & $($ (YY-II) & إيذاء الذأت \\
\hline | عا عبارة & $(Y-T T)$ & ألسلوك العدو اني \\
\hline 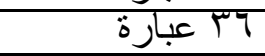 & & المجموع \\
\hline
\end{tabular}




\section{العدد العشرون لسنة 9 ا م ب م \\ Arr

$$
\text { مجلة البحث العلمى فى التربية }
$$

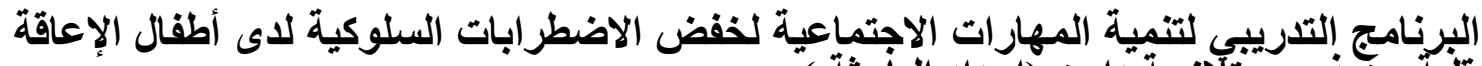

العقلية من ذوي متلّازمة داون (إعداد الباحثة ).

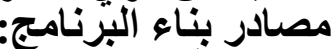

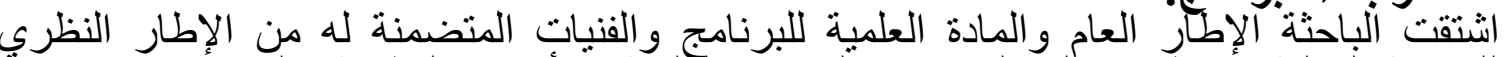

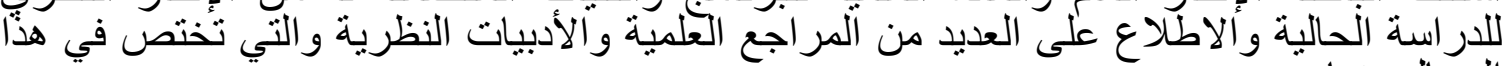

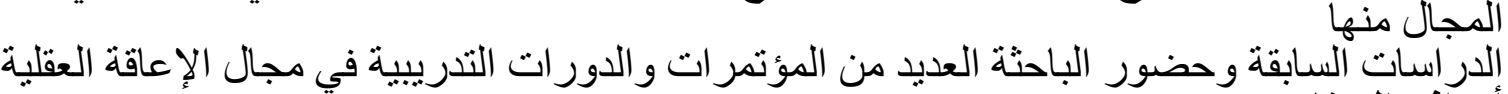

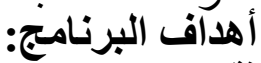

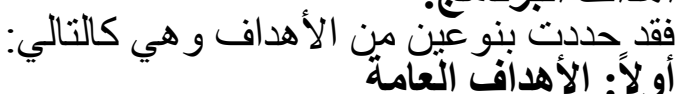

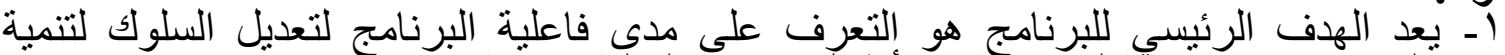

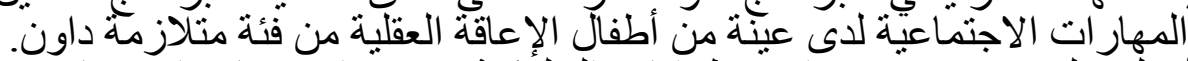

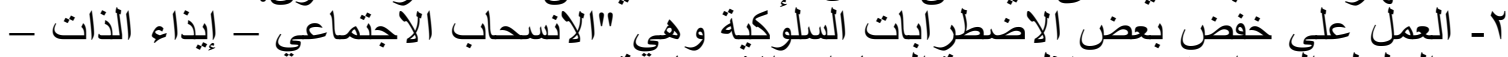

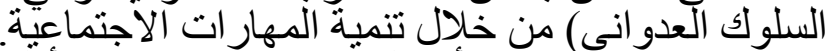

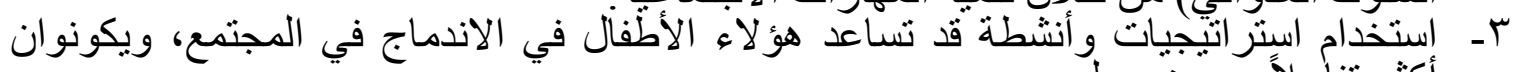

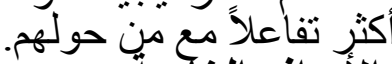

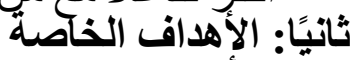
و هيّي الأهداف الإهداف الإجرائية التي تنتئق من الأهداف العامة وهي التي من المتوقع أن تحققها إجر اعات كل

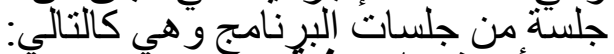

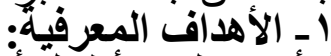

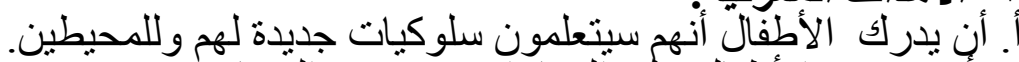

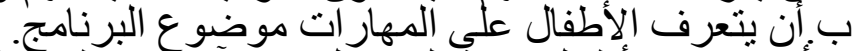

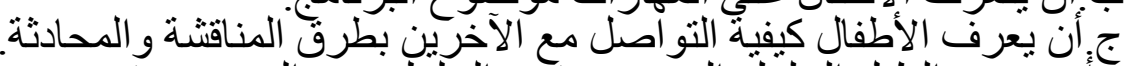

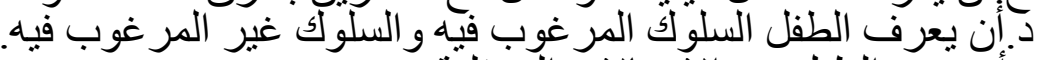
ه.أن يميز الطفل بين الانفعالات المات المختلفة

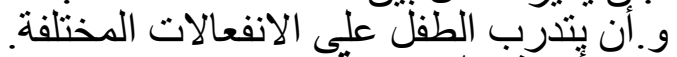

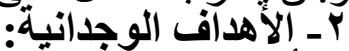

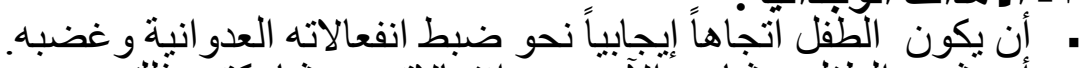

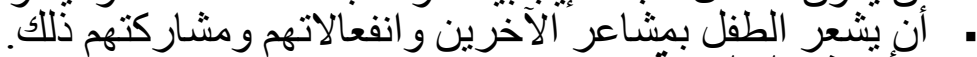

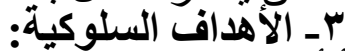

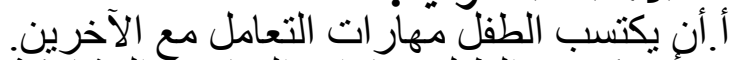

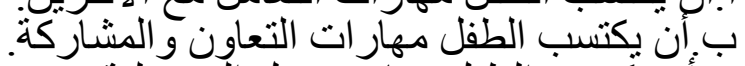
ج.أن يكتسب الطفل مهارة تحمل المكار المسئولية.

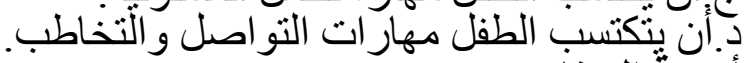

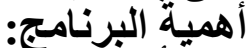

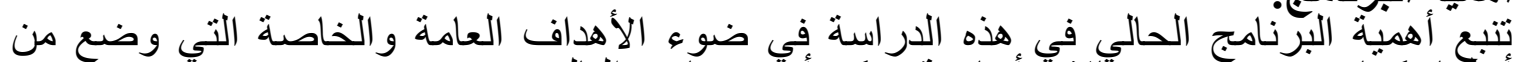

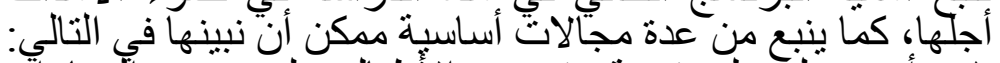

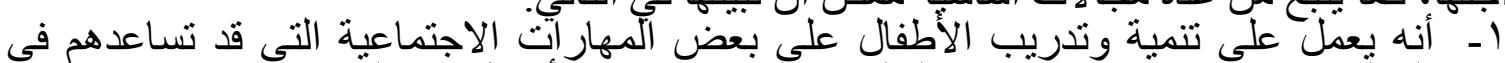

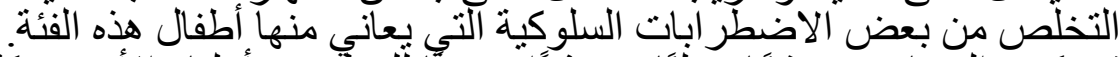

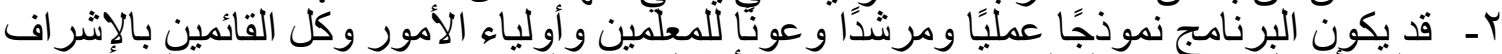

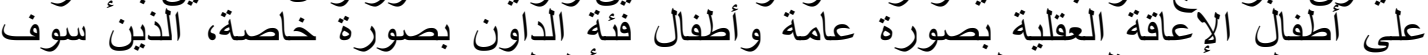
يستندون إلى نتأئج مثل هذه البر امج في تدريب هؤ لاء الأطفال.

الفنيات العلاجية المستخدمة في البرنامج:

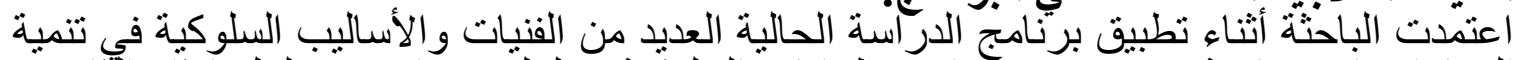

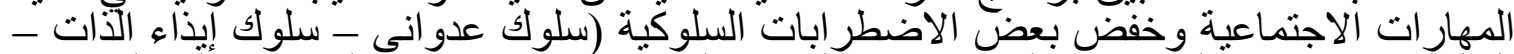

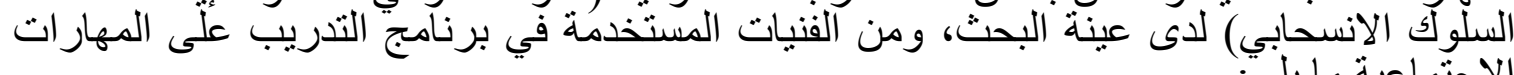
الاجتماعِية ما بلئي: التعزيز أُو التدعيّيّ، ، التوجيه "التعليمات"، الندذة ، المحاضرة والمناقثة الجماعية ، لعب الدور، التسلسل ، الحث و التلقين ، الاسترخاء، التغذية الراجعة أو المرتدة ، الواجبات المنزلية. 


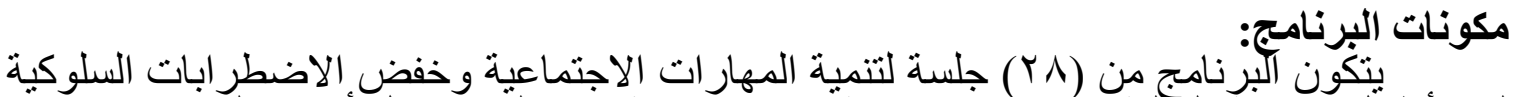

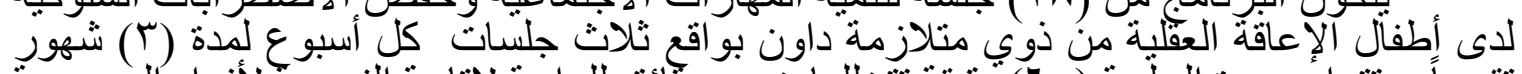

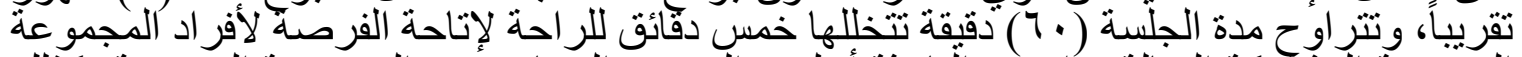

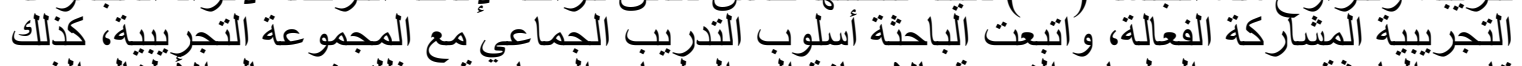

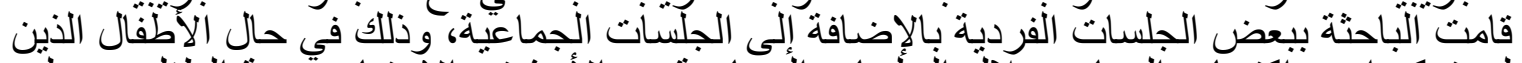

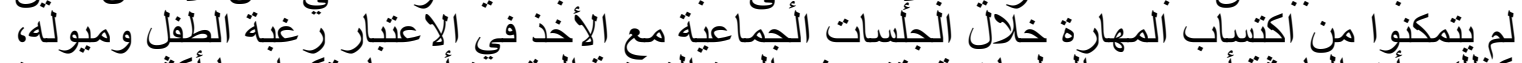

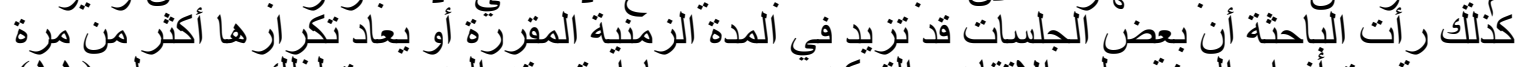

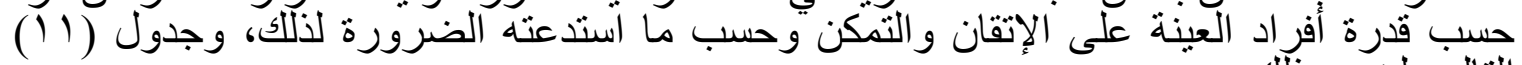

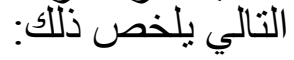

جدول (11) توزيع جلسات البرنامج التدريبي والهذف من كل جلسة

\begin{tabular}{|c|c|c|c|}
\hline الفتيات & الاهداق & عنوانج & p \\
\hline 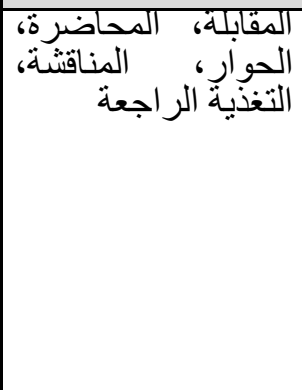 & 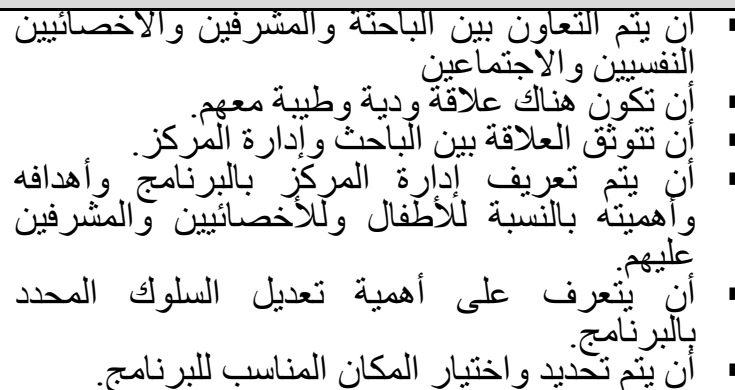 & 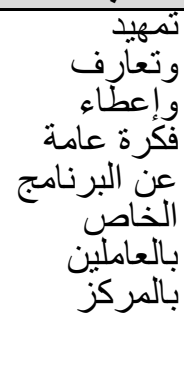 & الاولى \\
\hline المناقشاضةرة، الحوار، & 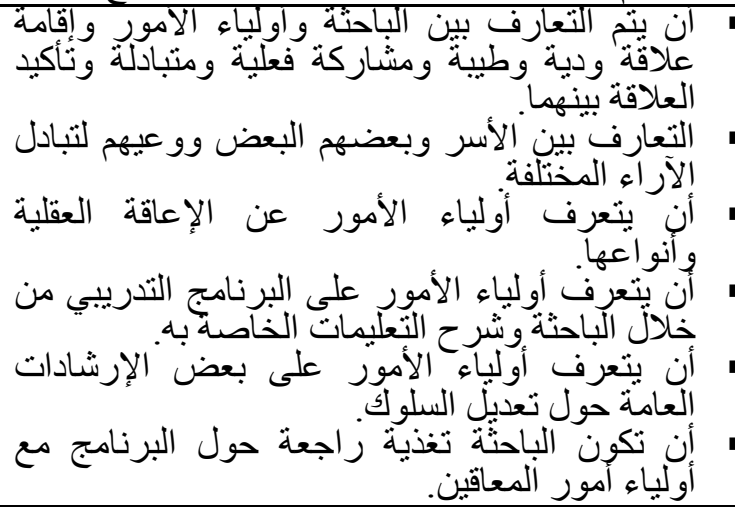 & 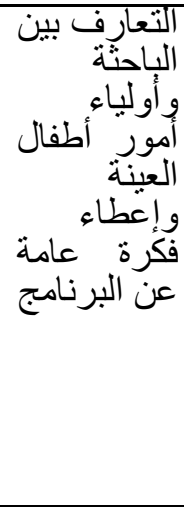 & الآنانية \\
\hline 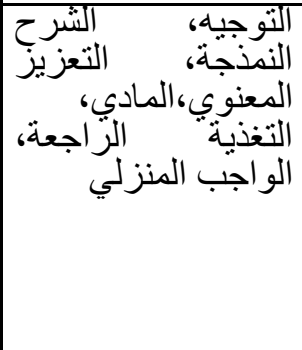 & 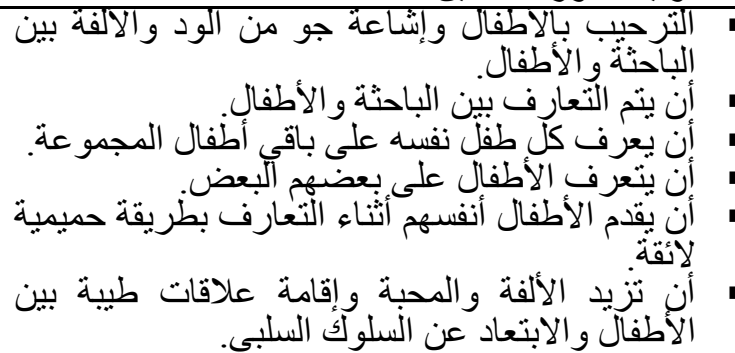 & والباحثنةٍ بين & النالتة \\
\hline 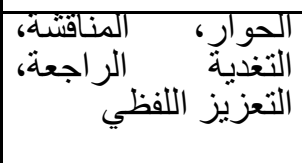 & 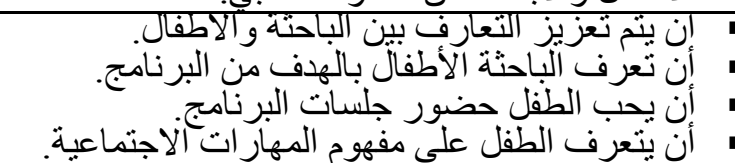 & التعزيزّ & الر ابعة \\
\hline 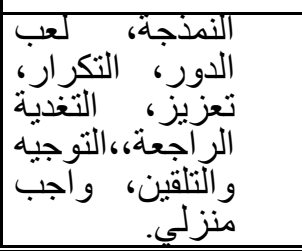 & 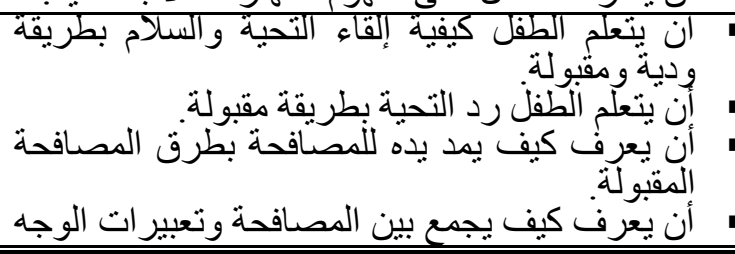 & والتحيّة & والسادسة \\
\hline
\end{tabular}




\begin{tabular}{|c|c|c|c|}
\hline الفتيات & & الحلّنيّة & r \\
\hline & 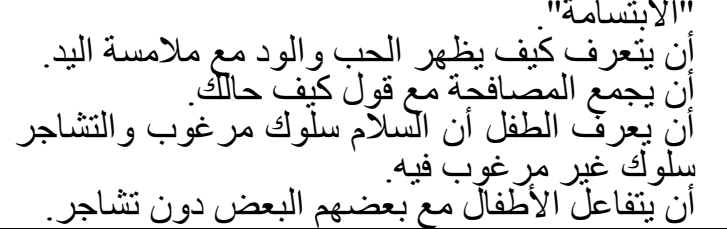 & & \\
\hline 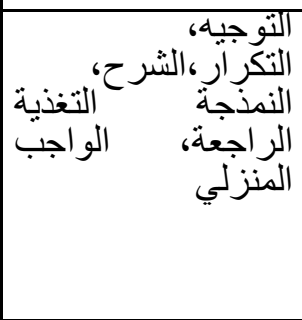 & 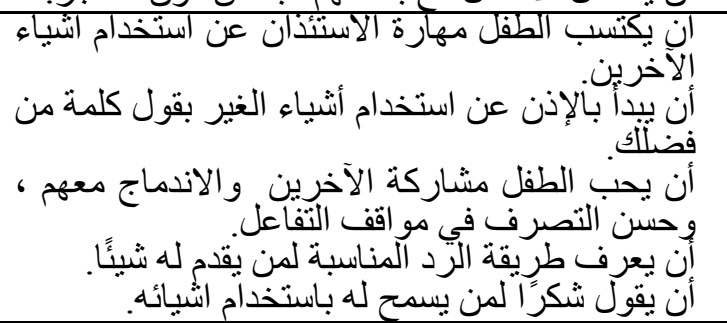 & 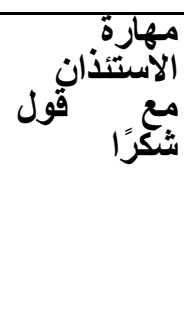 & السابعة \\
\hline 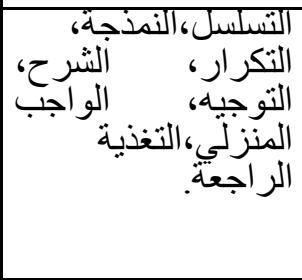 & 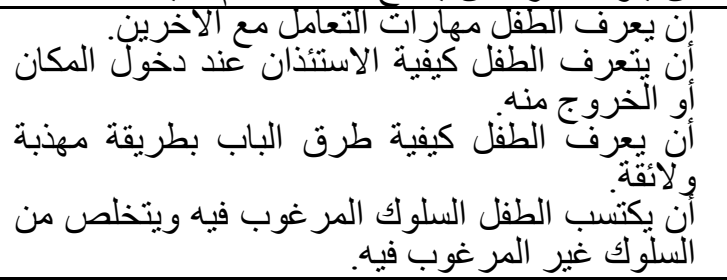 & 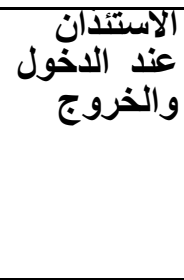 & النامنة \\
\hline 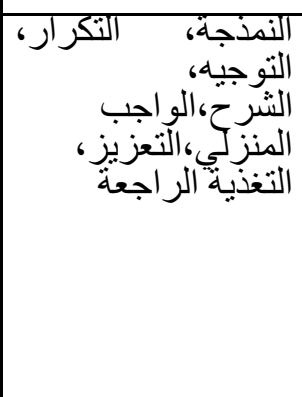 & 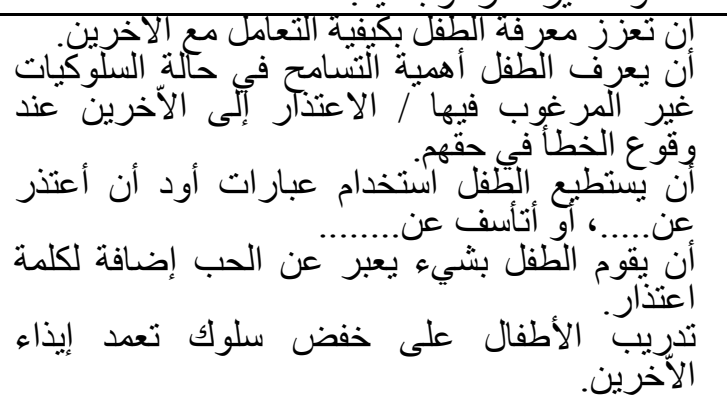 & الاعتَذار & التاسعحة \\
\hline 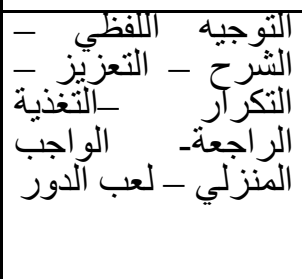 & 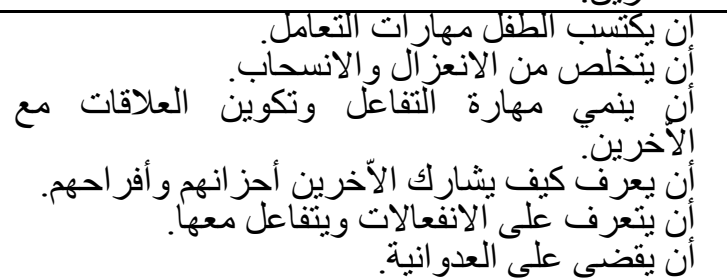 & 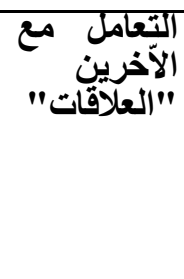 & والحاديةة \\
\hline 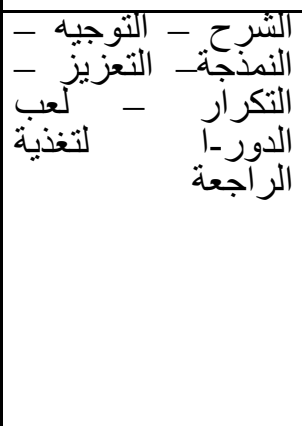 & 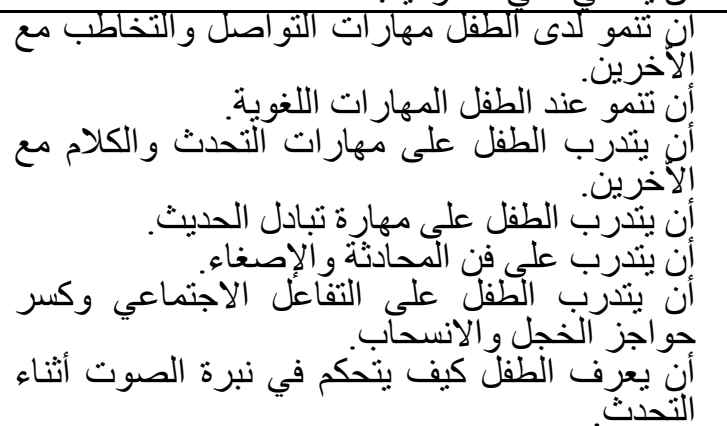 & والتخاطب & و الثراثثة \\
\hline 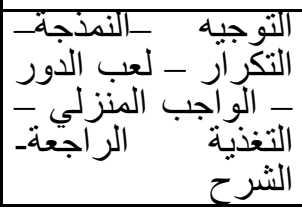 & 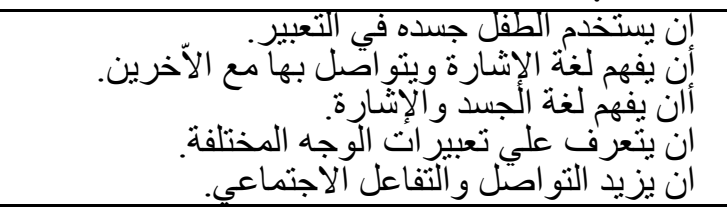 & التّزيزّل & الرشز ابعة \\
\hline 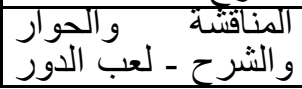 & 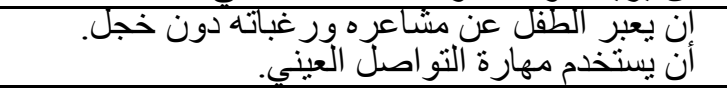 & الاجتماصل الإعي & | ل الخامسة \\
\hline
\end{tabular}




\begin{tabular}{|c|c|c|c|}
\hline القنيات & & & م \\
\hline 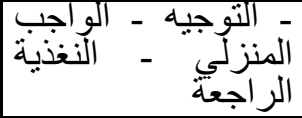 & 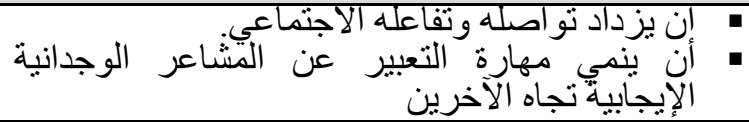 & بالمحادثـة & \\
\hline 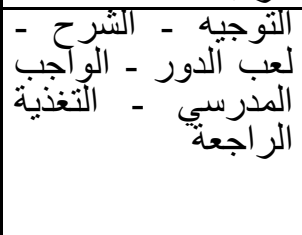 & 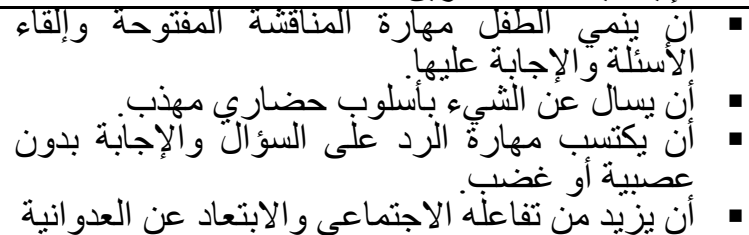 & ديث & والسابعة \\
\hline 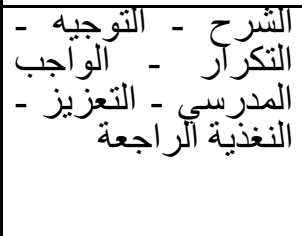 & 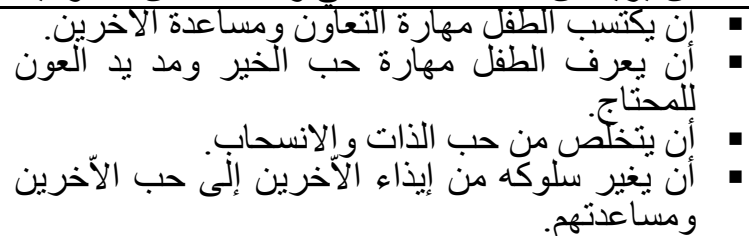 & الآّخرين & و التاسعة \\
\hline التوجرح الدور - التبه & 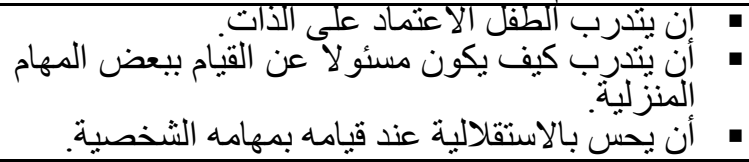 & & و العشرويةن \\
\hline 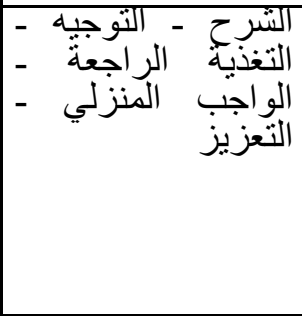 & 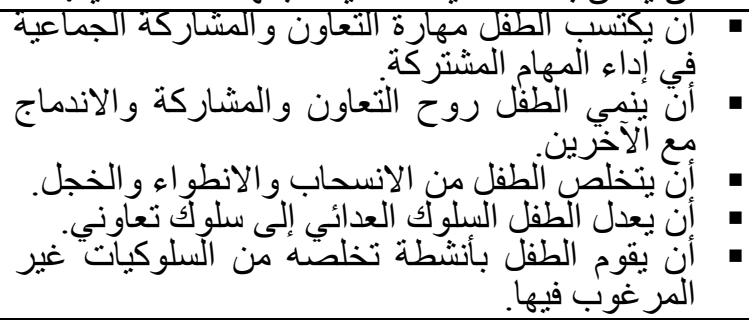 & & و العشرون \\
\hline 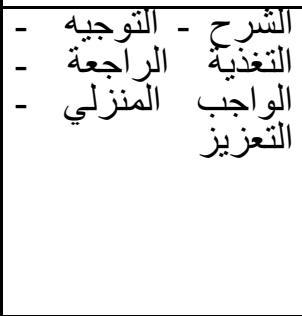 & 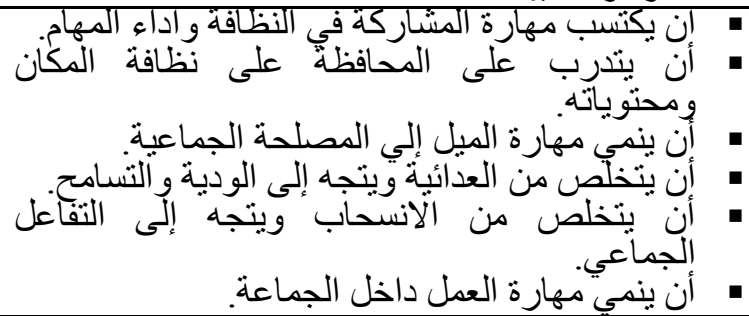 & نظفة & و العشرون \\
\hline 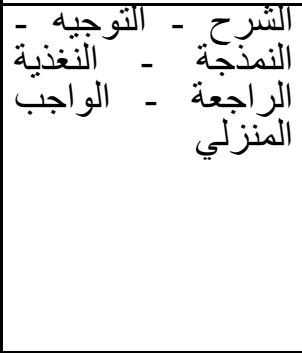 & 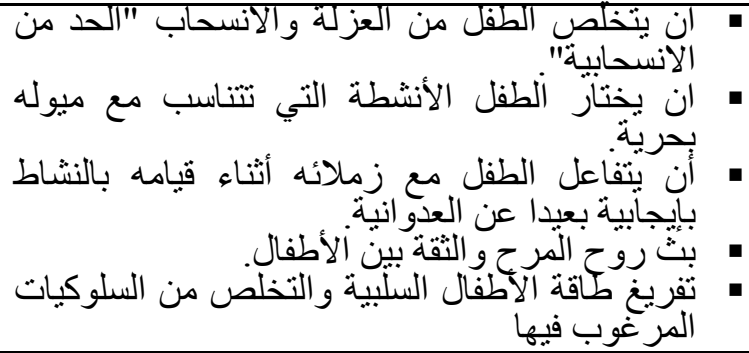 & 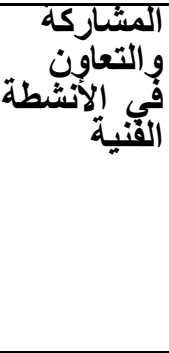 & و العشرون \\
\hline 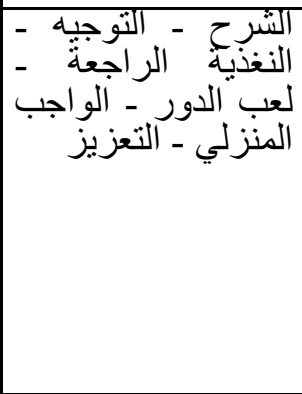 & 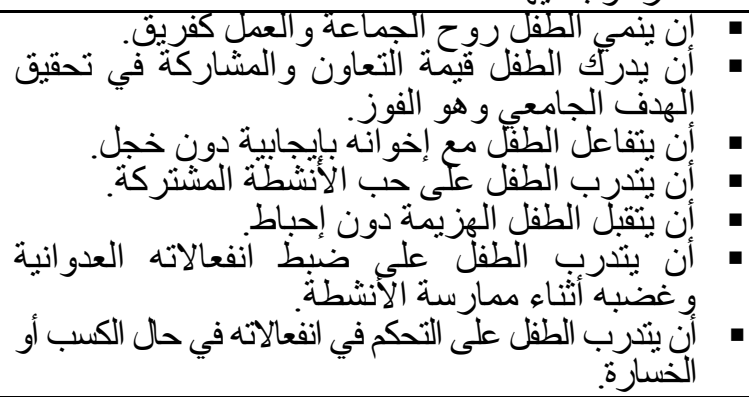 & "الجعارِّة & و العشرونة \\
\hline 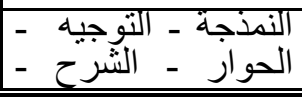 & 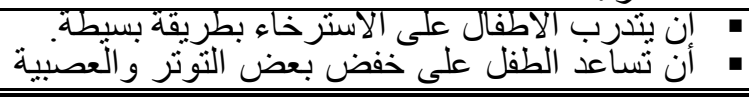 & على التّريب & و العشرونة \\
\hline
\end{tabular}




\begin{tabular}{|c|c|c|c|}
\hline الفنيات & الاهداف & عنوانة & b \\
\hline المنزلّي & 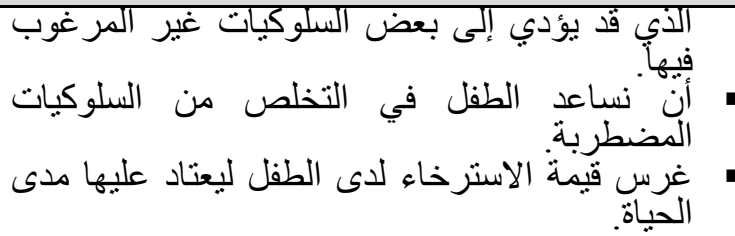 & الاسترخاء & \\
\hline 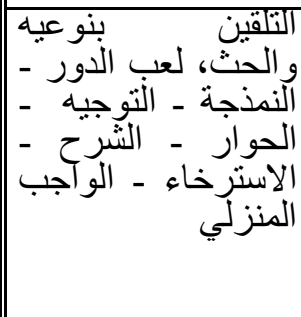 & 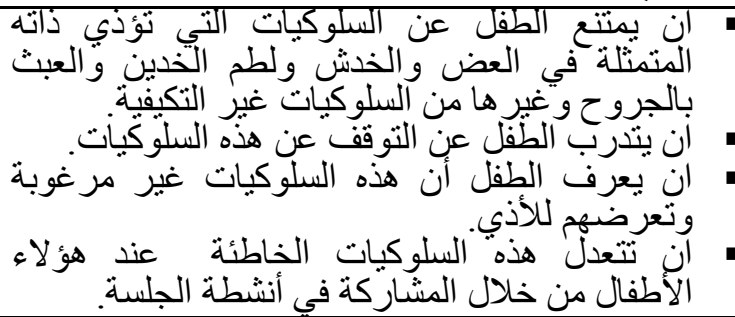 & 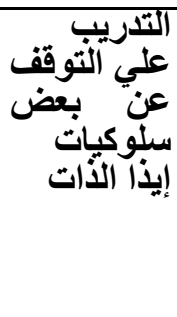 & و العشرون \\
\hline التعزيز - التوجيه & 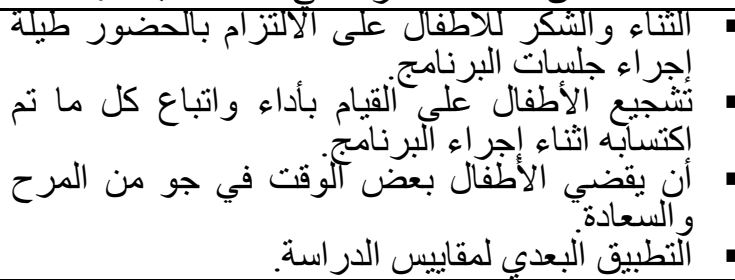 & الختّاميه & والعشرون \\
\hline
\end{tabular}

خامساً: الأساليب الإحصائية المستخدمة في البحث :

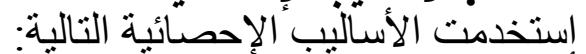

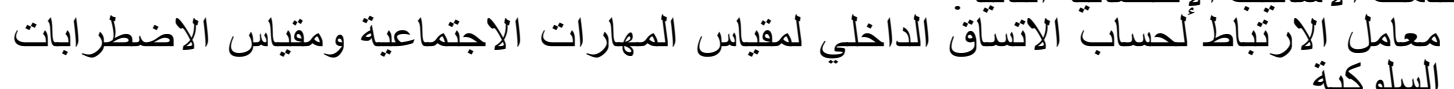

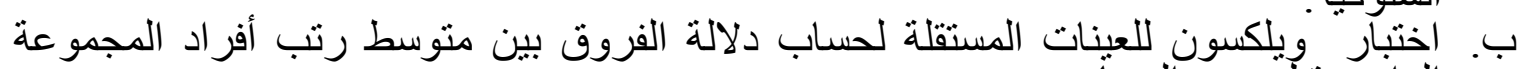

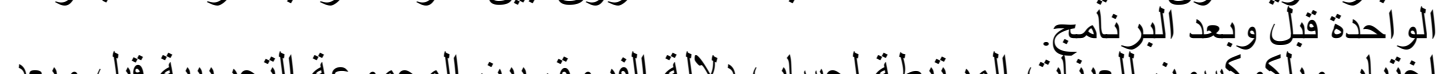

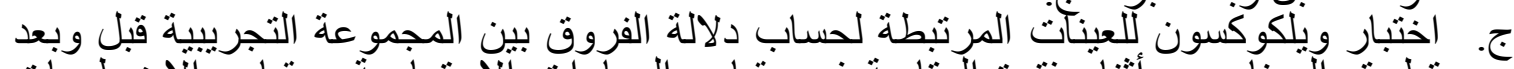

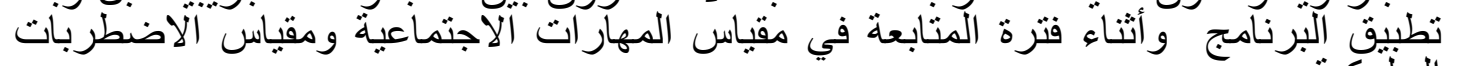

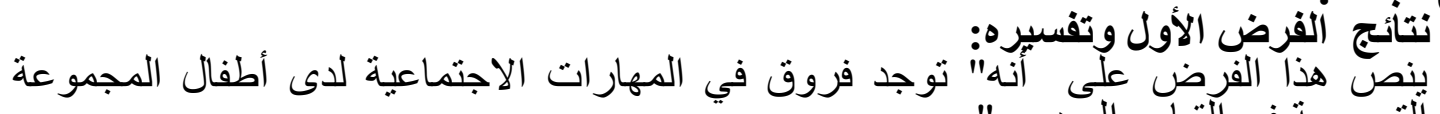
أولا: نتانج

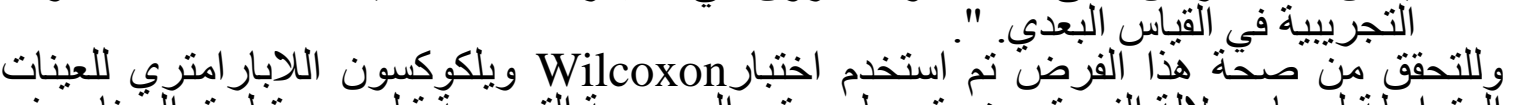

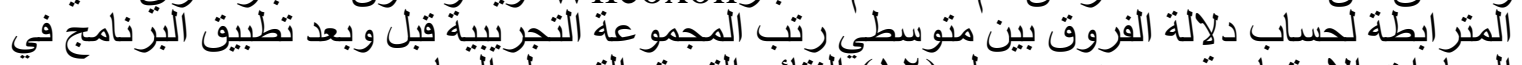

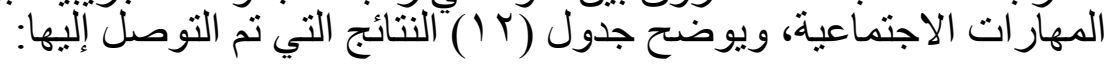

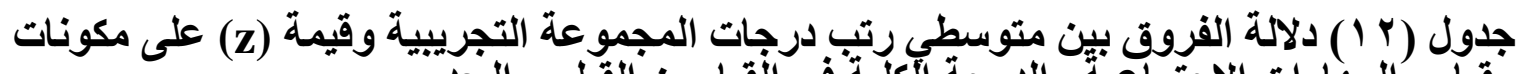

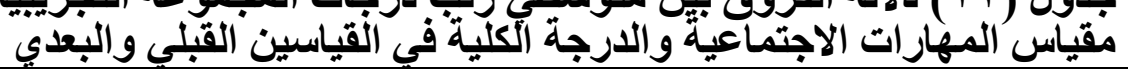

\begin{tabular}{|c|c|c|c|c|c|c|c|c|c|}
\hline مستوّي & فيم) & مَجمبوع & الرتبط & العدد & آتجاه الريتبق & الانحراف & المتوسط & آلقياس & المهارواتات \\
\hline \multirow{3}{*}{ 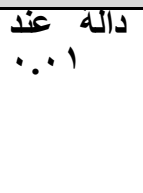 } & $T .7 \lambda \varepsilon$ & صفز & صفز & صفر & آلرتب السكالَّه & \multirow[b]{2}{*}{$r .10$} & \multirow[b]{2}{*}{$1 \leqslant . \gamma \wedge$} & \multirow{2}{*}{ فبلي } & \multirow{4}{*}{ التعامل الآخرين مص } \\
\hline & & $\xi 0$ & 0 & 7 & الموهتة & & & & \\
\hline & & & & صفر & التساوي & $<a r$ & $Y<$ & بعدي & \\
\hline \multirow{3}{*}{ داله ع. } & Fivo & صفر & صفر & صف & الرت الفيمولئ & 2.04 & $T 2 .$. & 1.9 & \\
\hline & & $\leqslant 0$ & 0 & & الولوجبة & r.10 & $1 \leq .11$ & & \multirow{2}{*}{ والتنخاطب } \\
\hline & & & & صفر & التّساوي & $\xi . \varepsilon$ & $T \Gamma .19$ & بعدي & \\
\hline
\end{tabular}




\begin{tabular}{|c|c|c|c|c|c|c|c|c|c|}
\hline & & & & 9 & المجموع & & & & \\
\hline \multirow{4}{*}{ داله بـ } & \multirow[t]{4}{*}{ T.TVV } & صفز & صفز & صفز & الرتب السالبه & \multirow[b]{2}{*}{ r.91 } & \multirow[b]{2}{*}{$1 . . \vee \Lambda$} & \multirow[t]{2}{*}{ فبلي } & \multirow{4}{*}{ و المشاركةن } \\
\hline & & \$0 & 0 & 9 & الرّتبة & & & & \\
\hline & & & & صفز & ألتساوي & \multirow[b]{2}{*}{ r.00 } & \multirow[b]{2}{*}{ IV... } & \multirow{2}{*}{ بعدي } & \\
\hline & & & & 9 & المجموع & & & & \\
\hline \multirow{4}{*}{ داله ب. } & $T .9 V T$ & صفز & صفر & صفز & الرتب السالبه & \multirow[b]{2}{*}{ T.00 } & \multirow[b]{2}{*}{$1 \leqslant .07$} & \multirow[t]{2}{*}{ فبلي } & \multirow{4}{*}{ الدمئولية } \\
\hline & & \&0 & 0 & 9 & الموجبة الرتب & & & & \\
\hline & & & & صفر & التساوي & \multirow[t]{2}{*}{$0.1 \mathrm{~V}$} & \multirow[t]{2}{*}{ T乏.. } & \multirow{2}{*}{ بعدي } & \\
\hline & & & & 9 & المجموع & & & & \\
\hline \multirow{4}{*}{ داله ب. } & T.TVV & صفُر & صفر & صفز & الرتب السنالبه & \multirow[t]{2}{*}{$1 \cdot .20$} & \multirow[t]{2}{*}{$0 \leqslant . Y Y$} & \multirow[t]{2}{*}{ قبلي } & \multirow[t]{4}{*}{ اللارجة الكلية } \\
\hline & & \&0 & 0 & 9 & الموحتة & & & & \\
\hline & & & & صفز & التساوي & \multirow[t]{2}{*}{ 10.TY } & \multirow[t]{2}{*}{11.19} & \multirow{2}{*}{ بعدي } & \\
\hline & & & & & المجموغ & & & & \\
\hline
\end{tabular}

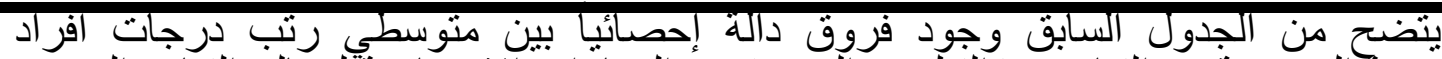

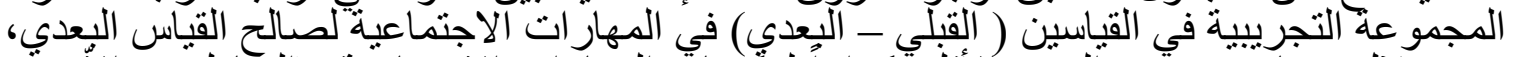

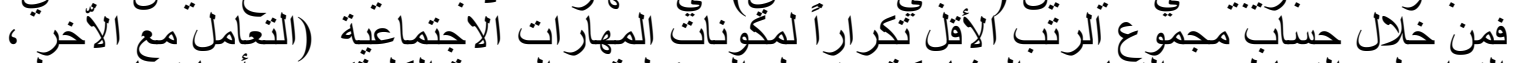

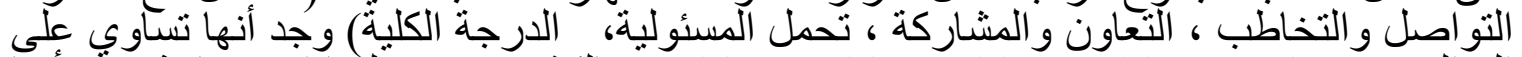

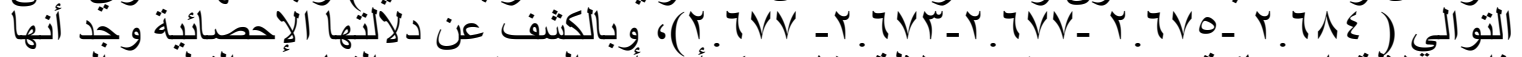

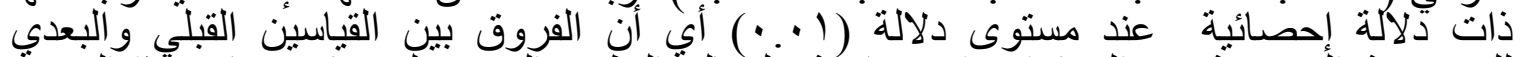

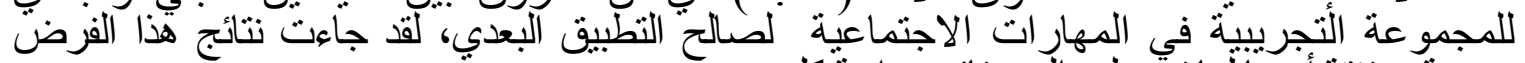

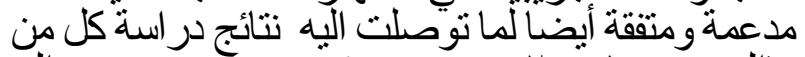

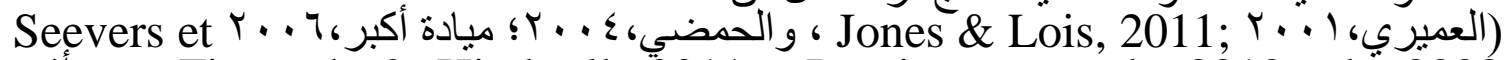
رأفت ; Firoozeh \& Hjarbrall, 2011 ; Remington et al. ,2010; al., 2008;

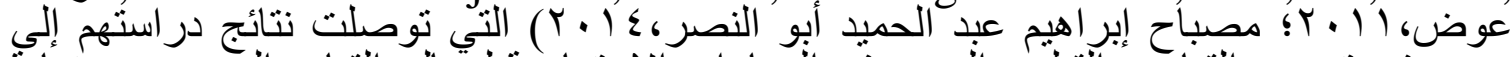

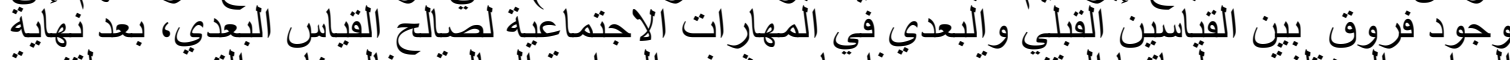

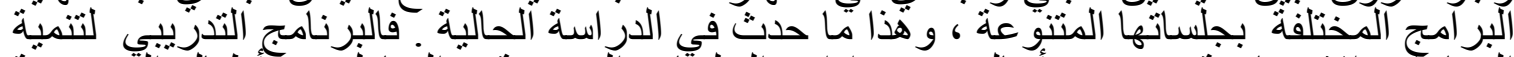

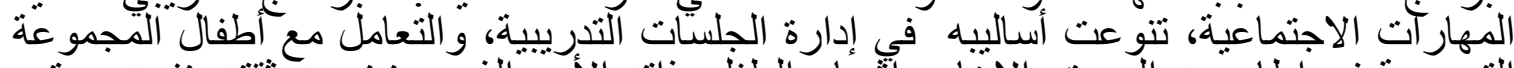

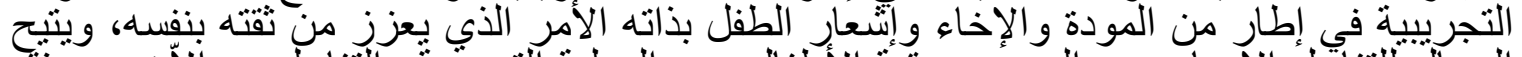

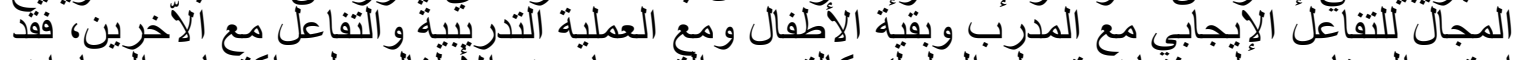

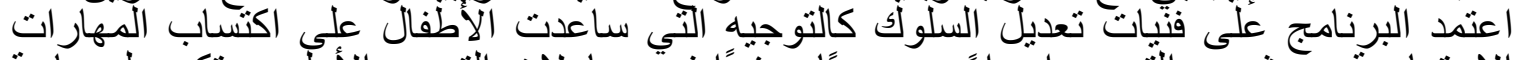

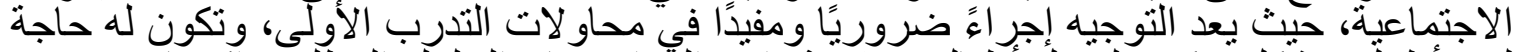

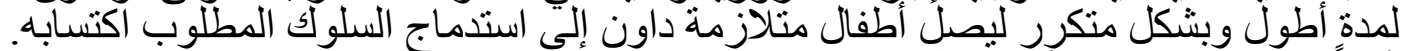

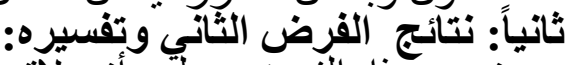

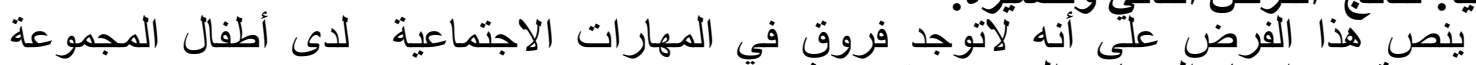

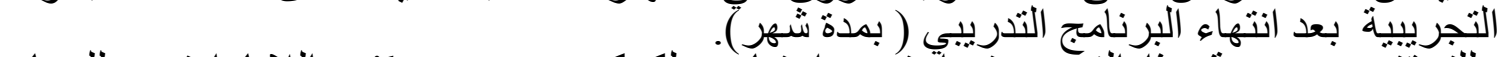

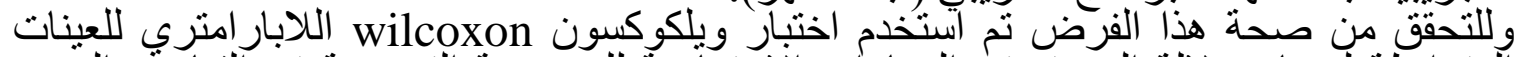

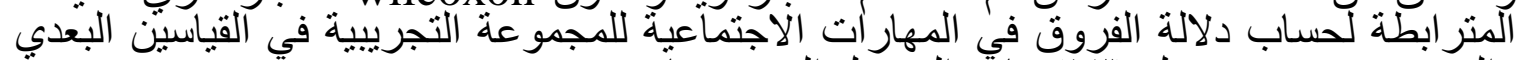

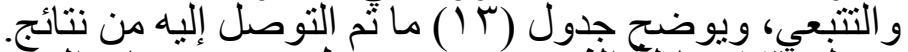

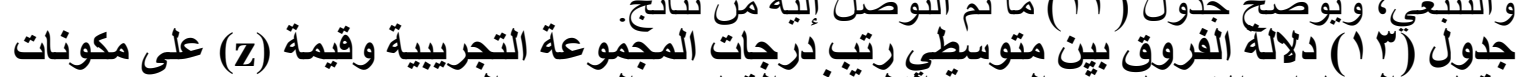

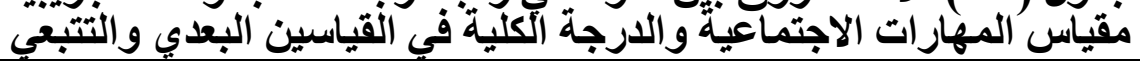

\begin{tabular}{|c|c|c|c|c|c|c|c|c|c|}
\hline مستوية الالاية & $\begin{array}{l}\text { فيم) } \\
(\mathbf{Z})\end{array}$ & مجموع الزرتب & متوسط الرتب & العدد & اتجاه فروت & الالنحراف & المتوسط & القياس & 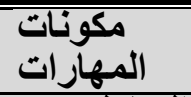 \\
\hline 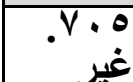 &.$r \vee \wedge$ & 17 & $\varepsilon$ & $\xi$ & السالية الرثب & \multirow[b]{2}{*}{ 乏.Or } & \multirow[b]{2}{*}{$r \varepsilon .}$. & \multirow[t]{2}{*}{ بعدي } & \multirow[t]{4}{*}{ الأخرمل مع } \\
\hline دالَّة & & TY & $\xi$ & $\Gamma$ & الموجبةّة الرتب & & & & \\
\hline & & & & T & التسكاوي & \multirow[b]{2}{*}{$\varepsilon . \mu$} & \multirow[b]{2}{*}{$r r . \wedge q$} & \multirow[t]{2}{*}{ تثبعي } & \\
\hline & & & & 9 & المجموع & & & & \\
\hline.$V \cdot 0$ &.$r \vee \Lambda$ & 7 & $\Gamma$ & T & الرتب & $\varepsilon . \cdot \varepsilon$ & YT.Aq & بعدي & التواصل \\
\hline
\end{tabular}




\begin{tabular}{|c|c|c|c|c|c|c|c|c|c|}
\hline غيرِ & & & & & السالبه & & & & والتخاطب \\
\hline دالَّة & & $\varepsilon$ & T & $Y$ & الموجبة الرتب & & & & \\
\hline & & & & 0 & التساوي & \multirow[b]{2}{*}{$\varepsilon . r$} & \multirow[b]{2}{*}{ rT.VA } & \multirow{2}{*}{ تثبعي } & \\
\hline & & & & 9 & المجموع & & & & \\
\hline غير &.$\leqslant \leqslant V$ & 7 & $\Gamma$ & $r$ & السالثبة & \multirow[b]{2}{*}{$r .00$} & \multirow[b]{2}{*}{$1 V .}$. & \multirow[t]{2}{*}{ بعدي } & \multirow{4}{*}{ والتعشاِنَّكة } \\
\hline دالثة & & 9 & $\Gamma$ & $\Gamma$ & الموتبة & & & & \\
\hline & & & & $\varepsilon$ & الآتشاوي & \multirow[b]{2}{*}{ Y.VI } & \multirow[b]{2}{*}{18.11} & \multirow{2}{*}{ تثبعي } & \\
\hline & & & & 9 & المجموع & & & & \\
\hline .95 & $1.10 \mathrm{~V}$ & 1. & T.O. & $\varepsilon$ & الرتب & \multirow[b]{2}{*}{$0.1 \mathrm{~V}$} & \multirow[b]{2}{*}{$r \varepsilon .}$. & \multirow[t]{2}{*}{ بعدي } & \multirow{4}{*}{ المسئولية } \\
\hline & & صفر & صفز & صفر & الموجبة الرتب & & & & \\
\hline & & & & 0 & التساوي & \multirow[t]{2}{*}{0.7.} & \multirow[t]{2}{*}{ YY.A9 } & \multirow{2}{*}{ تثبعي } & \\
\hline & & & & 9 & المجمو غ & & & & \\
\hline \multirow{4}{*}{ دالئلة 9} & $1.7 \mathrm{Vq}$ & $r 9.0$ & $0 . Y 1$ & $\mathrm{~V}$ & ألرثبت & \multirow[t]{2}{*}{ TO.T } & \multirow[t]{2}{*}{$\wedge \wedge . \wedge 9$} & \multirow[t]{2}{*}{ بعدي } & الإرجة \\
\hline & & 1.0 & \&.Yo & Y & المه حتبّة & & & & \\
\hline & & & & صفز & التساوي & \multirow[t]{2}{*}{10.19} & \multirow[t]{2}{*}{ NV. $7 V$} & \multirow{2}{*}{ تثتبعي } & \\
\hline & & & & 9 & المجموع & & & & \\
\hline
\end{tabular}

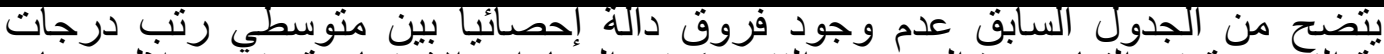

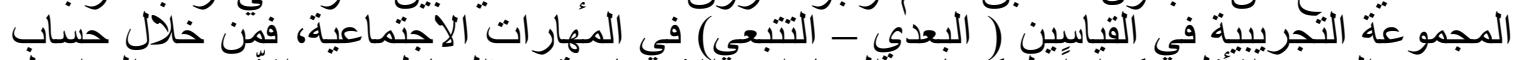

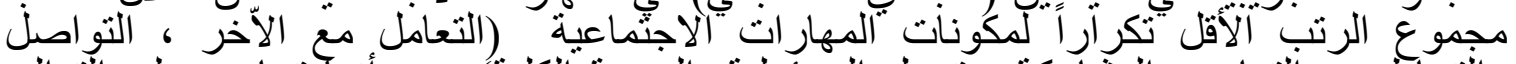

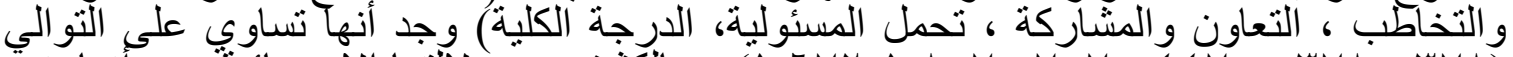

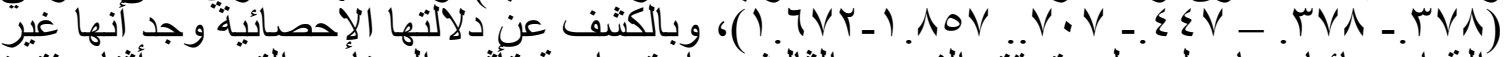

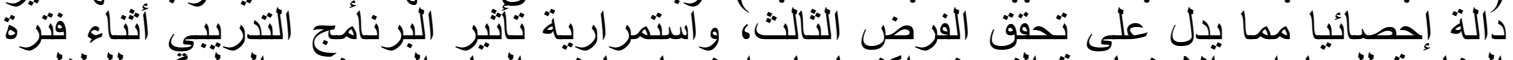
المتابعة للمهار ات ألاجتماعية التي تم اكتسابها واستدماجها في البناء المعرفي والني السلوكي للطفل ،

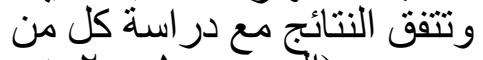

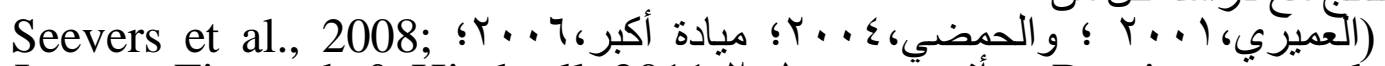

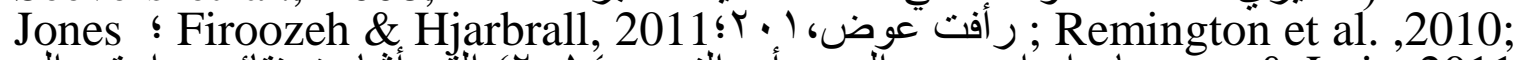
عود \& \&ois, 2011

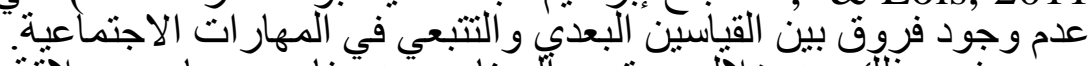

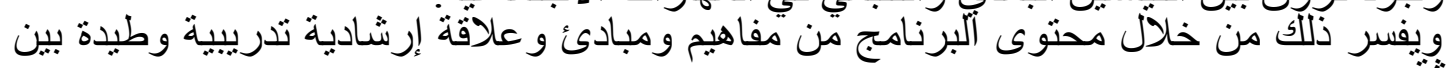

و أُطفال المجمو عة التجريبية، و الوعي بالأفكار الإيجابية المرتبطة بالمهار ات الاجتماعية، كما يفسر

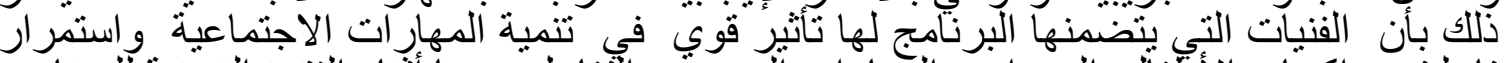

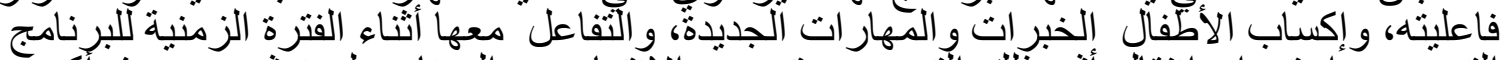

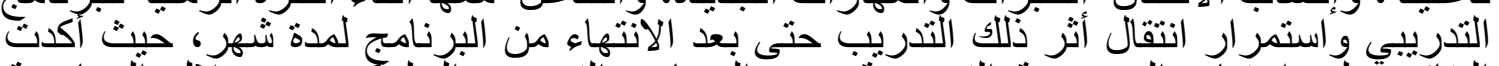

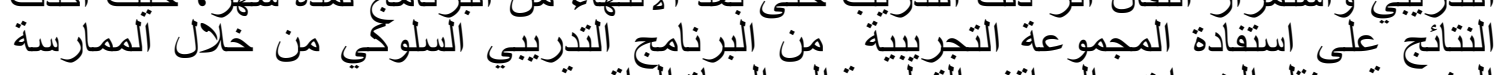

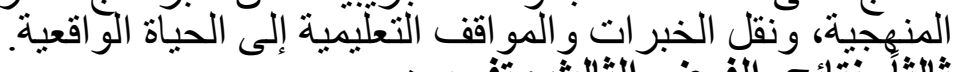

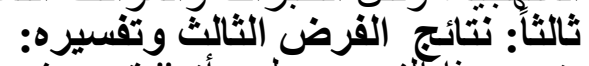

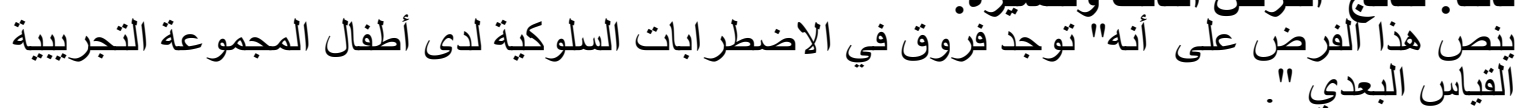

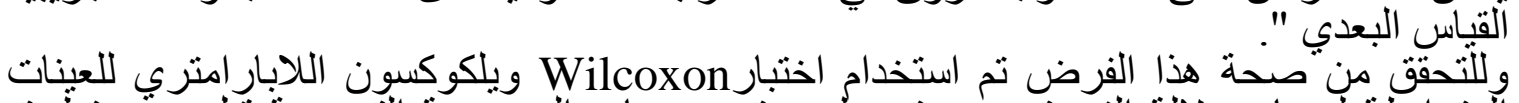

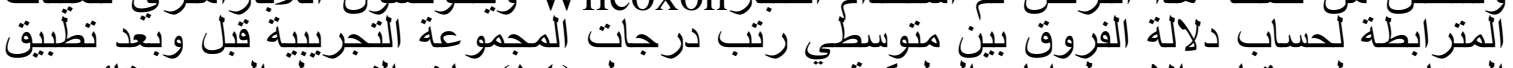

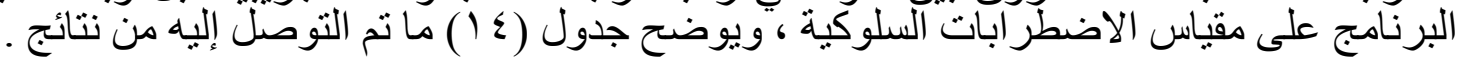




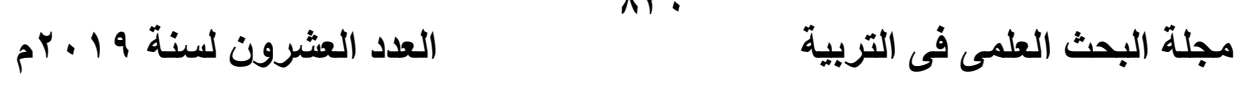

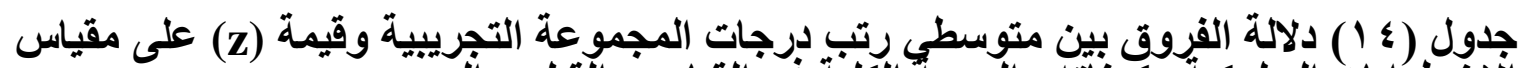

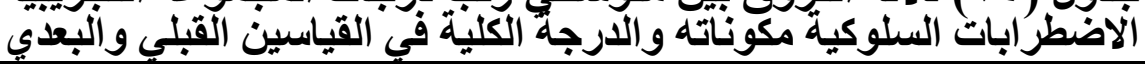

\begin{tabular}{|c|c|c|c|c|c|c|c|c|c|}
\hline مستوّي & فيماd & مجموعب & متوسط الرتب & العدد ا العد & اتجاه الروتب & الانحراف & المتوسط & القياس & الاضطوراباتة \\
\hline \multirow{4}{*}{ 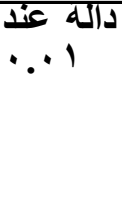 } & \multirow[t]{4}{*}{ T.TVV } & $\leqslant 0$ & $\dot{0}$ & 9 & الرثتب السآلبه & \multirow[b]{2}{*}{ r.OY } & \multirow[b]{2}{*}{1.11} & \multirow{2}{*}{ قبلي } & \multirow{4}{*}{ الاجتماعحي } \\
\hline & & صفز & صفر & صفز & المو الرتبة & & & & \\
\hline & & & & صفز & التساوي & \multirow[b]{2}{*}{ r... } & \multirow[b]{2}{*}{$11 . \varepsilon \varepsilon$} & \multirow[t]{2}{*}{ بعدي } & \\
\hline & & & & 9 & المجموع & & & & \\
\hline \multirow{4}{*}{$\begin{array}{l}\text { داله عن } \cdot 1 \\
. .1\end{array}$} & \multirow[t]{4}{*}{ T.TVV } & $\leqslant 0$ & 0 & 9 & الرتب السالبها & \multirow[b]{2}{*}{$\varepsilon . \varepsilon V$} & \multirow[b]{2}{*}{$r \leq . r T$} & \multirow[t]{2}{*}{ فبلي } & \multirow[t]{4}{*}{ إيذاء الذات } \\
\hline & & صفز & صفز & صفز & الإرتبة & & & & \\
\hline & & & & صفز & التّساوي & \multirow[b]{2}{*}{$0 . \Lambda Y$} & \multirow[b]{2}{*}{17.19} & \multirow[t]{2}{*}{ بعدي } & \\
\hline & & & & 9 & المجموع & & & & \\
\hline \multirow{4}{*}{ 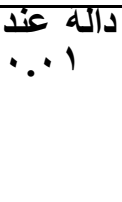 } & \multirow[t]{4}{*}{ T. TVT } & $\xi 0$ & 0 & 9 & الرتب السالبهة & \multirow[t]{2}{*}{$T .11$} & \multirow[t]{2}{*}{ TV.07 } & \multirow[t]{2}{*}{ هبلي } & \multirow{4}{*}{ العدواني } \\
\hline & & صفز & صفز & صفر & الموحتبة & & & & \\
\hline & & & & صفز & التساوي & \multirow[t]{2}{*}{0.9} & \multirow[t]{2}{*}{17.19} & \multirow[t]{2}{*}{ بعدي } & \\
\hline & & & & 9 & المجموغ & & & & \\
\hline \multirow{4}{*}{$\begin{array}{l}\text { داله عن } \cdot 1 \\
. .1\end{array}$} & \multirow[t]{4}{*}{ T.771 } & $\varepsilon 0$ & 0 & 9 & الرثب السالبها & \multirow[t]{2}{*}{1.10} & \multirow[t]{2}{*}{$\lambda \Gamma . . \cdot$} & \multirow[t]{2}{*}{ فبلي } & \multirow[t]{4}{*}{ الارجه الكليه } \\
\hline & & صفز & صفز & صفر & الموجبة الرتب & & & & \\
\hline & & & & صفز & التساوي & \multirow[t]{2}{*}{ TI.Yर } & \multirow[t]{2}{*}{$E V . Y Y$} & \multirow{2}{*}{ بعدي } & \\
\hline & & & & 9 & المجموع & & & & \\
\hline
\end{tabular}

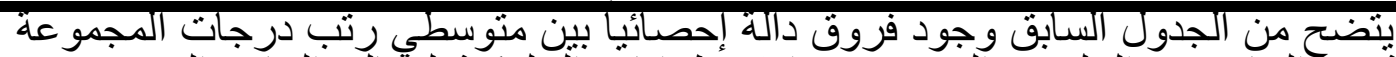

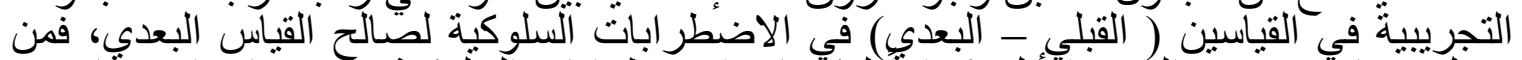

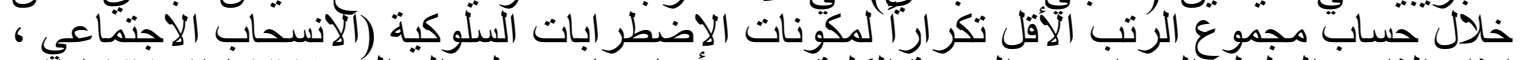

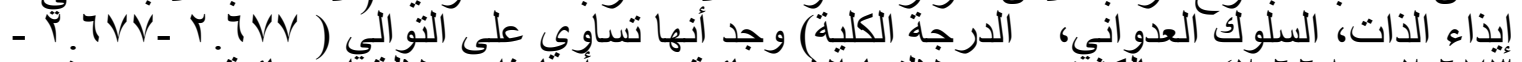

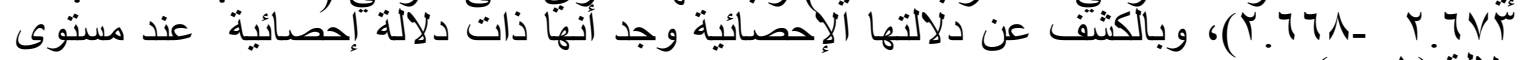

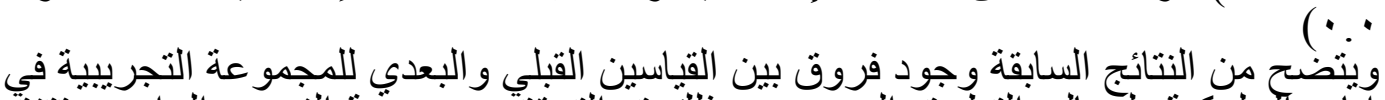
دلالة (1)

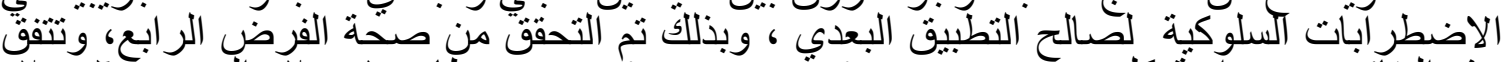

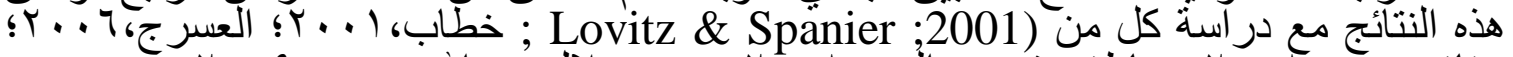

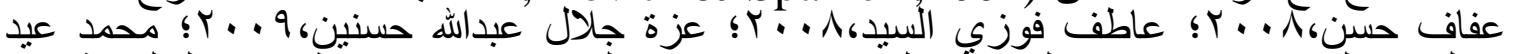

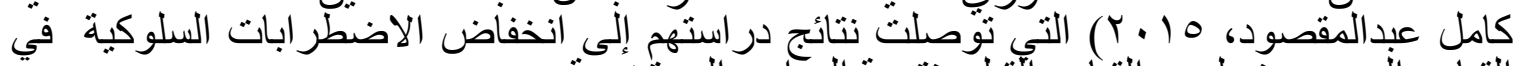

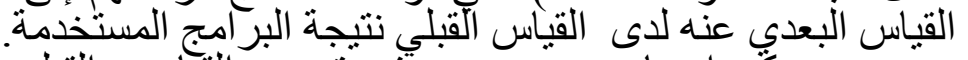

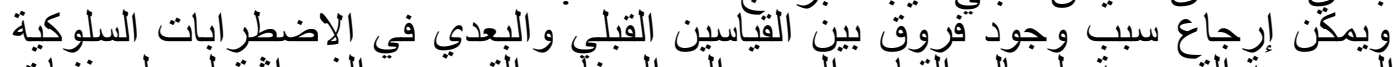

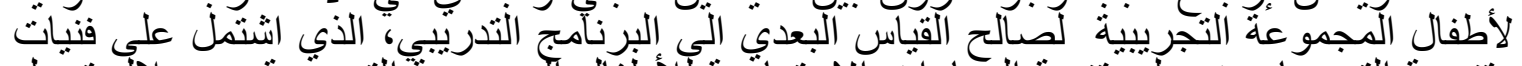

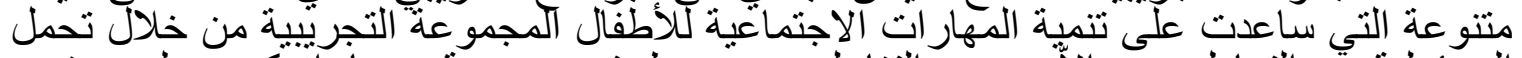

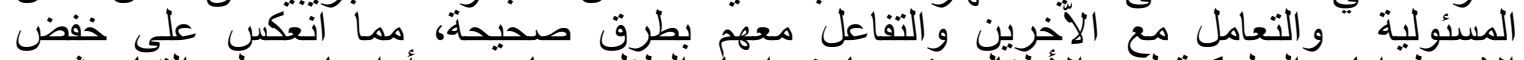

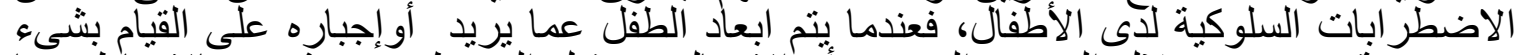

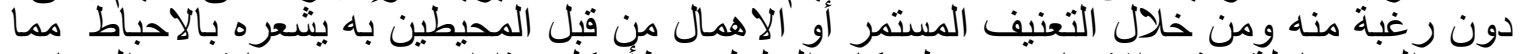

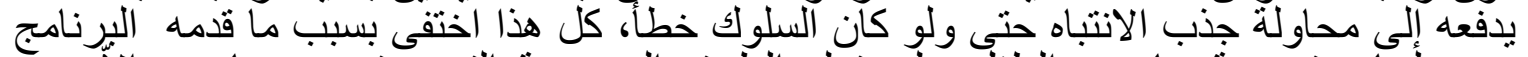

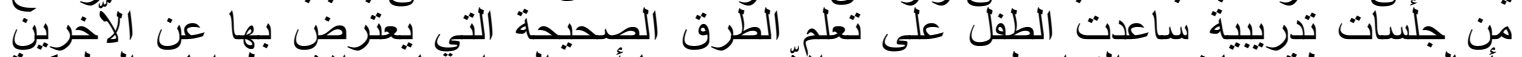

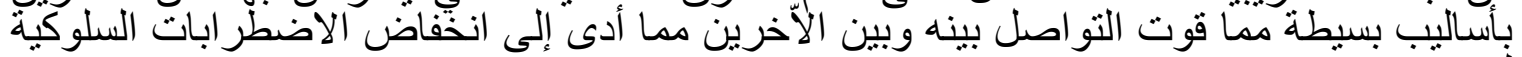

رابعاً: نتائج الفرض الر ابع وتفسيره:

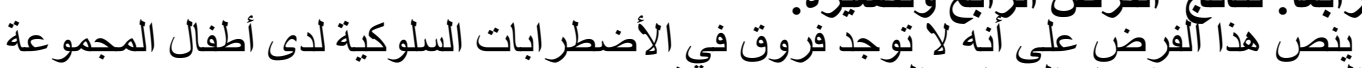

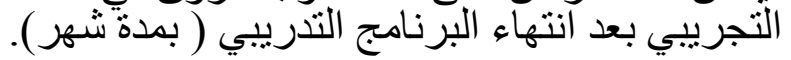




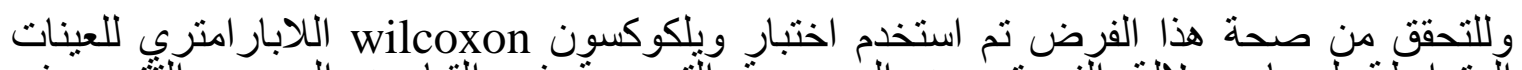

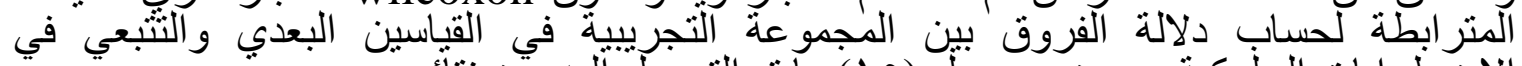

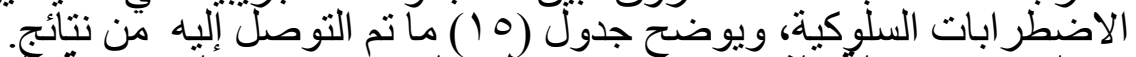

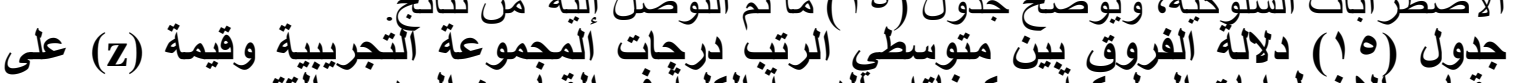

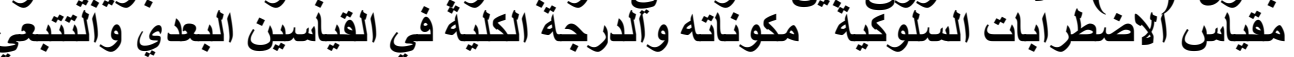

\begin{tabular}{|c|c|c|c|c|c|c|c|c|c|}
\hline مستوبي & 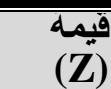 & ألرتبوع & منتوتبط & العلد & آتجاه & الانحراق & المتّوسط & القياس & الاضطورابيةت \\
\hline \multirow{4}{*}{ غير دالةً } & \multirow[t]{4}{*}{$1.11 \xi$} & $\dot{\Lambda}$ & $\dot{\varepsilon}$ & T & الرتب الساكلبه & \multirow[b]{2}{*}{$r .}$. & \multirow[b]{2}{*}{$1 \% . \varepsilon \varepsilon$} & \multirow[t]{2}{*}{ بعدي } & \multirow{4}{*}{ الاجتماعابي } \\
\hline & & Y. & $\xi$ & 0 & الموجبة الربّ & & & & \\
\hline & & & & T & التّساوي & \multirow[b]{2}{*}{ r.90 } & \multirow[b]{2}{*}{ IT.VA } & \multirow{2}{*}{ تَتبعي } & \\
\hline & & & & 9 & المجموغ & & & & \\
\hline \multirow{4}{*}{ غير دالة VT } &.$r \cdot Y$ & 17 & $\varepsilon$ & $\varepsilon$ & الرتب السالبية & \multirow[b]{2}{*}{$0 . \wedge Y$} & \multirow[b]{2}{*}{17.19} & \multirow[t]{2}{*}{ بعدي } & \multirow[t]{4}{*}{ إيذاء الأات } \\
\hline & & T. & 0 & $\varepsilon$ & الموجبة الربّ & & & & \\
\hline & & & & $T$ & التساوي & \multirow[b]{2}{*}{0.14} & \multirow[b]{2}{*}{$1 V .}$. & \multirow[t]{2}{*}{ تثتبعي } & \\
\hline & & & & 9 & المجموغ & & & & \\
\hline \multirow{4}{*}{ غير دالةُ } & $1 . \cdots$ & Tr & r.Vo & $\varepsilon$ & الرتب السالبه & \multirow[t]{2}{*}{0.7} & \multirow[t]{2}{*}{17.19} & \multirow[t]{2}{*}{ بعدي } & \multirow{4}{*}{ العدواني } \\
\hline & & 7 & $r$ & T & المرتبية & & & & \\
\hline & & & & $r$ & التّساوي & \multirow[b]{2}{*}{$\varepsilon . V Y$} & \multirow[b]{2}{*}{17.07} & \multirow[t]{2}{*}{ تثبعي } & \\
\hline & & & & 9 & المجموع & & & & \\
\hline \multirow{4}{*}{ غير دالة } & $.1 \wedge 9$ & 17 & $\varepsilon$ & $\varepsilon$ & الرتب السالبه & \multirow[t]{2}{*}{ IT.KA } & \multirow[t]{2}{*}{ EV.YT } & \multirow[t]{2}{*}{ بعدي } & \multirow[t]{4}{*}{ الارجه الكليه } \\
\hline & & Y. & 0 & $\varepsilon$ & الموجبة الرتب & & & & \\
\hline & & & & $T$ & التساوي & \multirow[b]{2}{*}{ Ir.OV } & \multirow[b]{2}{*}{$\varepsilon V . r T$} & \multirow{2}{*}{ تتبعي } & \\
\hline & & & & 9 & المجموع & & & & \\
\hline
\end{tabular}

يتضح من الجدول السابق عدم وجود فروق دالة إحصائيا بين متوسطي رتب درجات الزبات

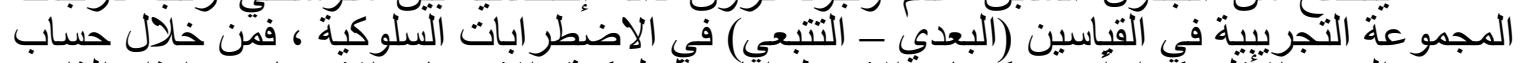

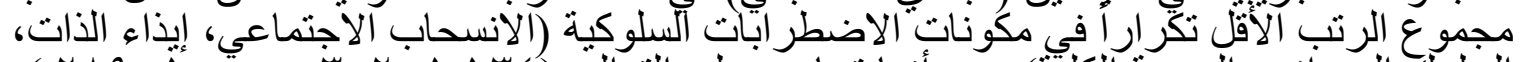

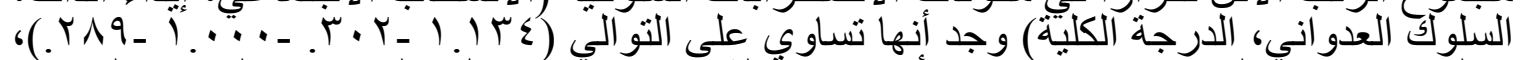

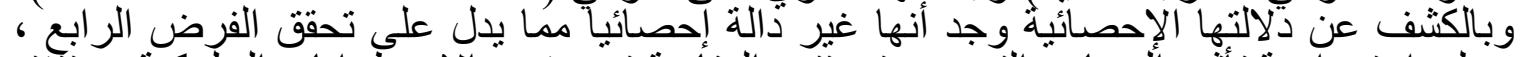

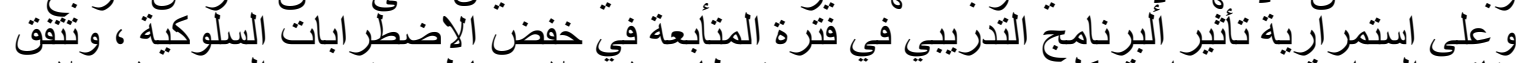

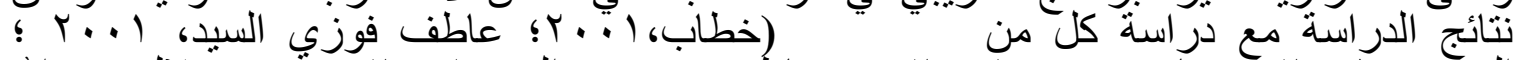

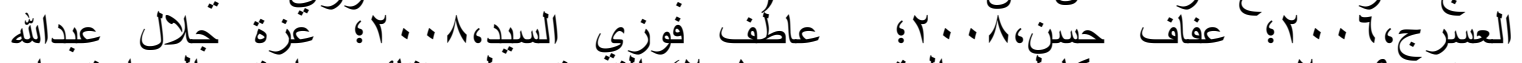

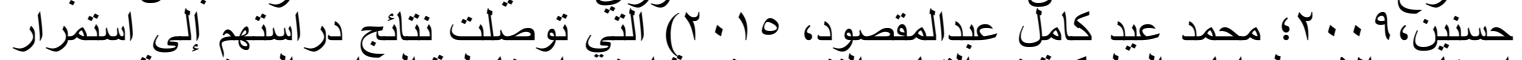

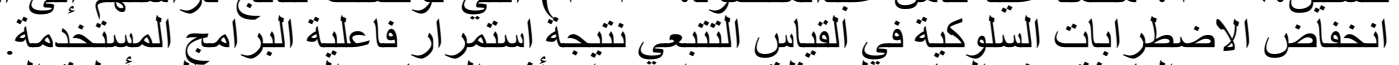

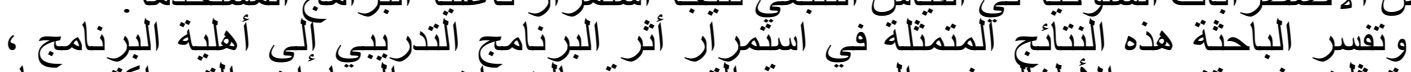

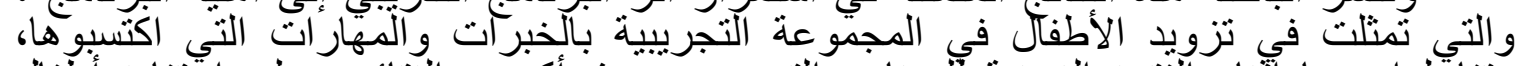

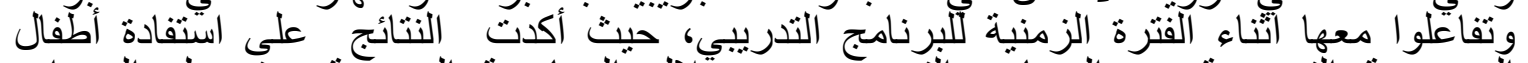

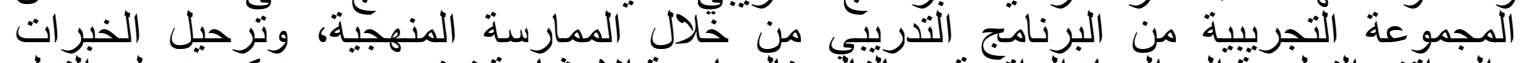

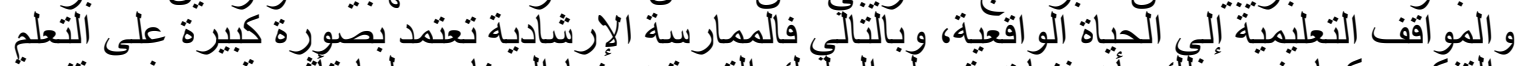

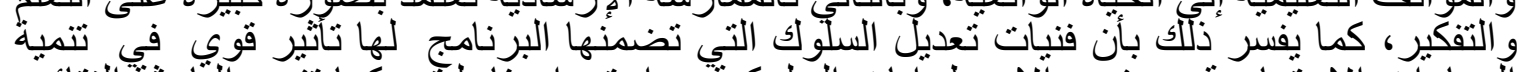

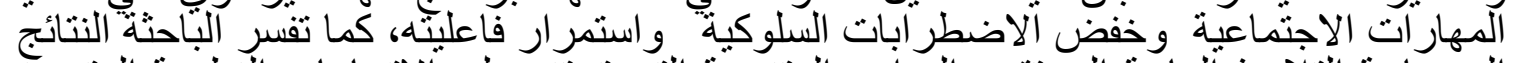

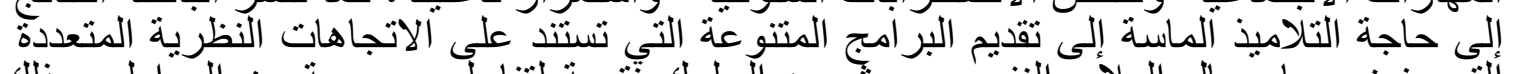

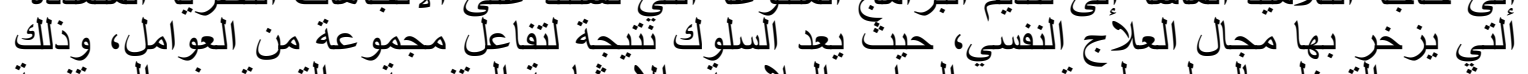

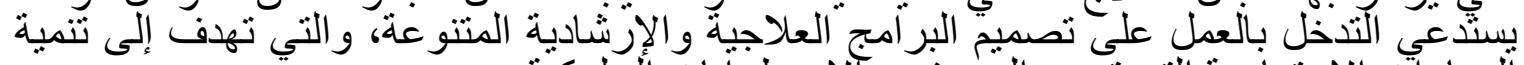

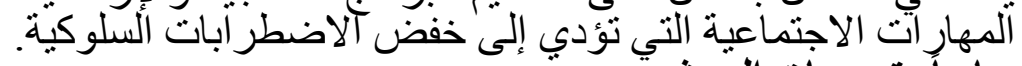
سابعا: توصيات البرت البحث:

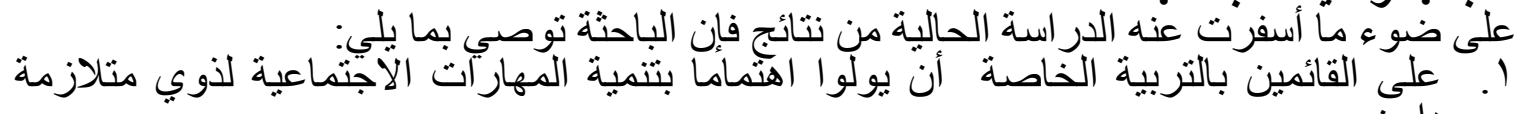

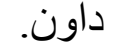




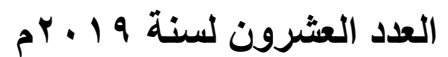

\section{مجلة البحث العلمى فى التربية}

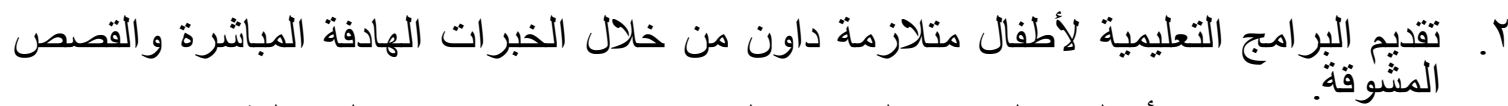

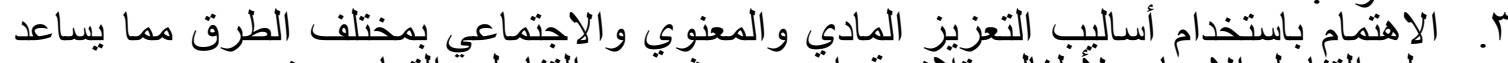

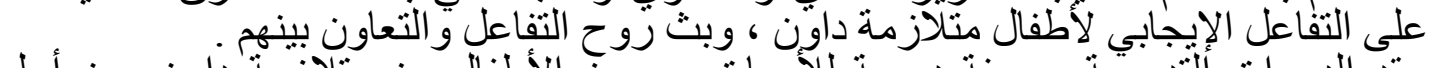

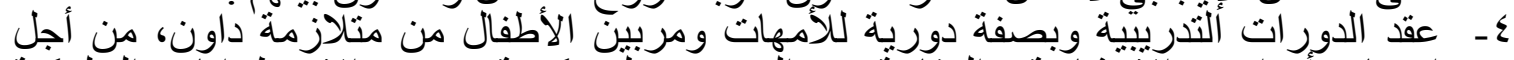

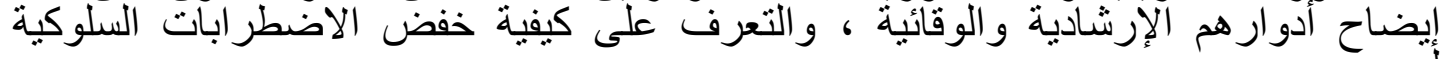

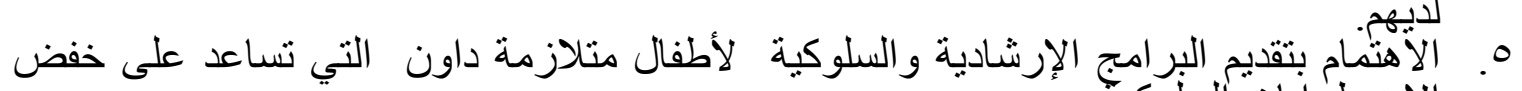

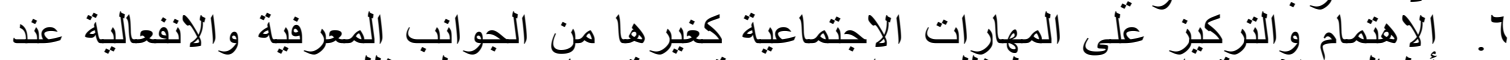

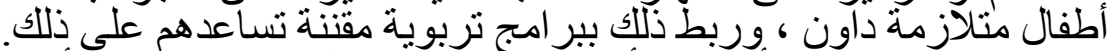

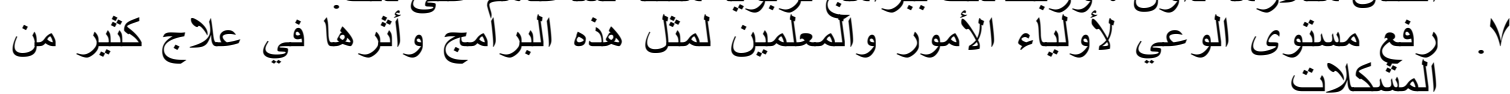

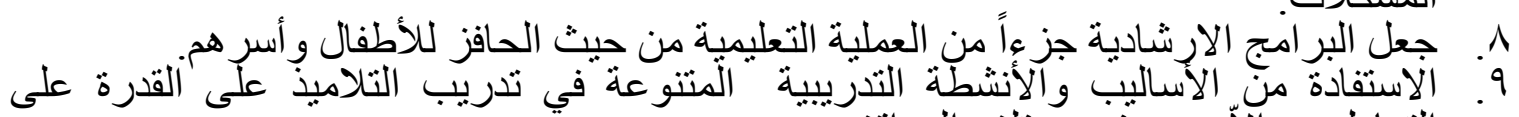

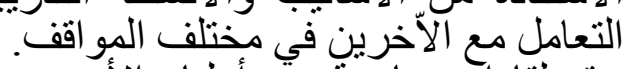

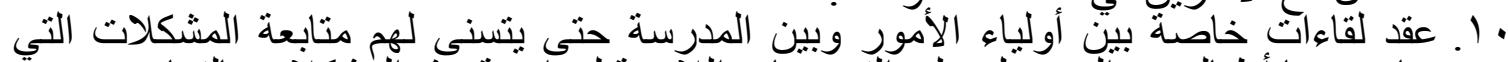

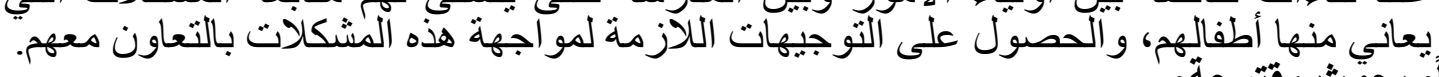

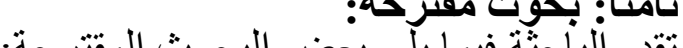

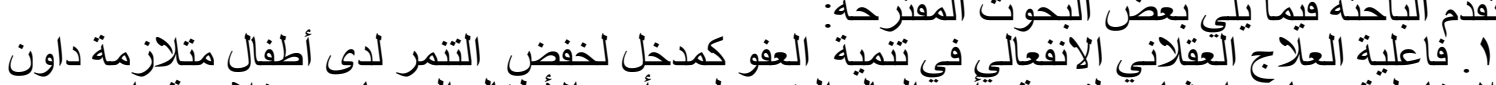

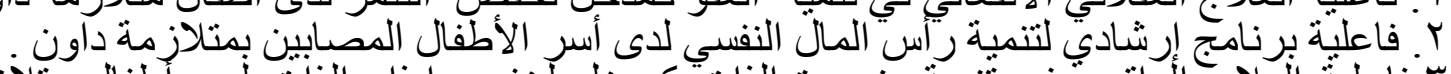

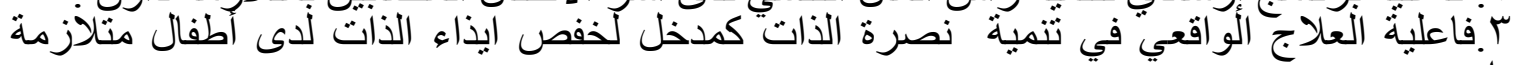
داون.

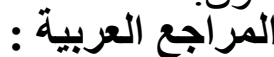

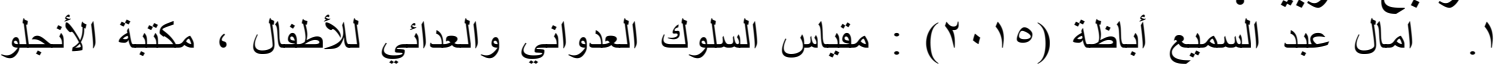
المصرية ، القاهرة.

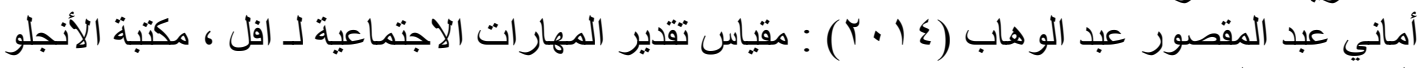
المصرية ، القاهرة و أماني جميل العطار (10 (10) : مقياس المشكلات السلوكية ، مطبعة الثمس ،

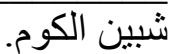

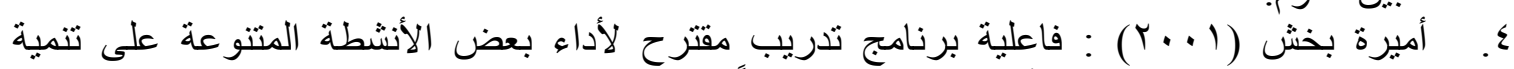

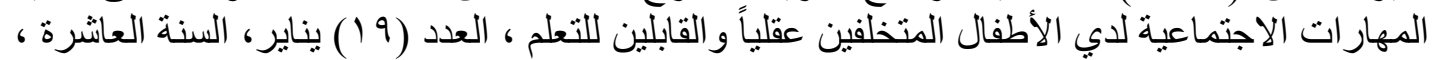

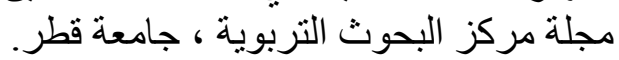

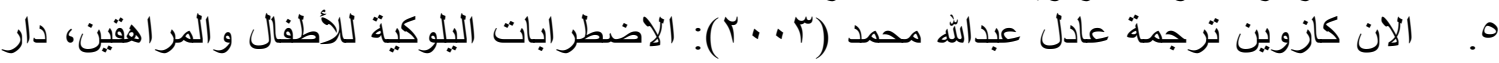
راثد، القاهرة.

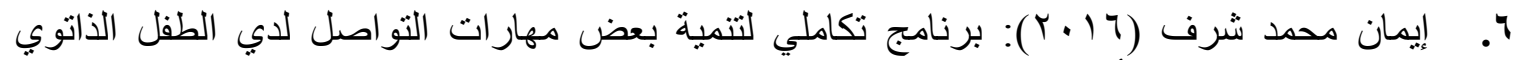

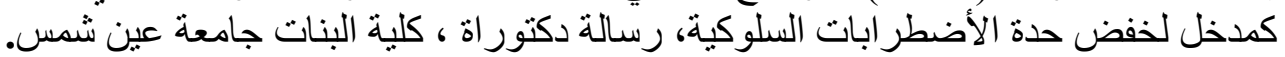

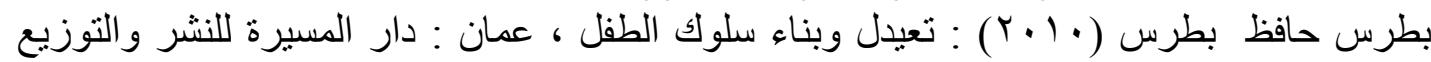

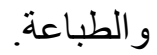

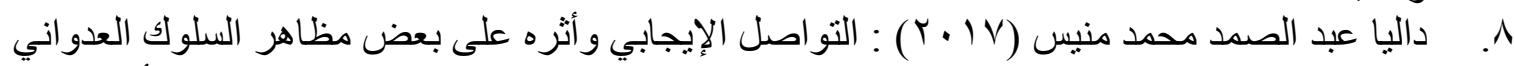

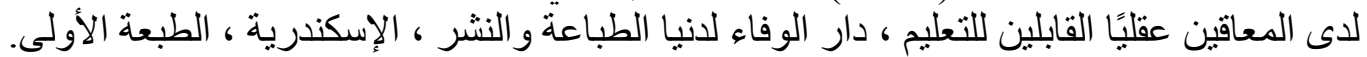

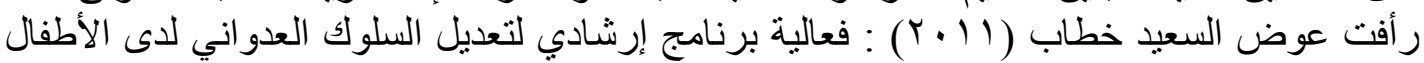

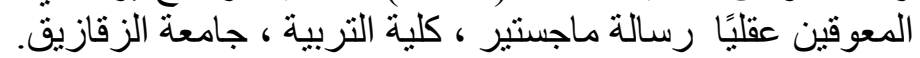

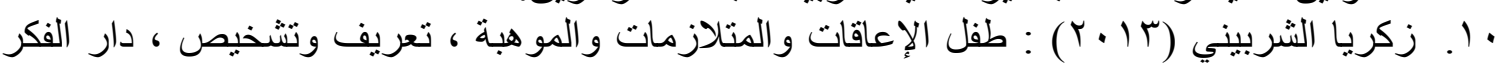
العربي ، القاهرة. 


\section{مجلة البحث العلمى فى التربية}

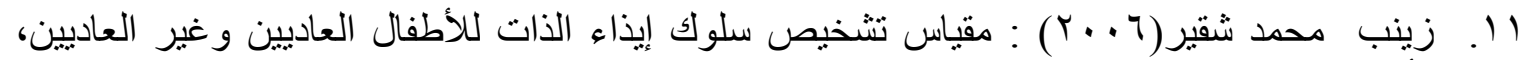
مكتبة الأنجلو المصرية ، والقاهرة

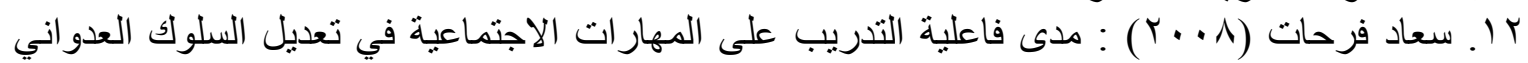

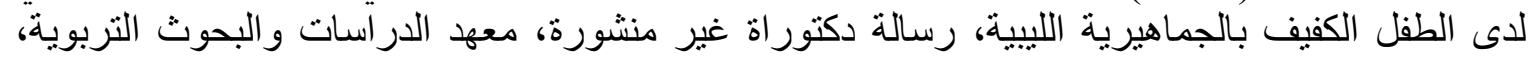
جامعة القاهرة.

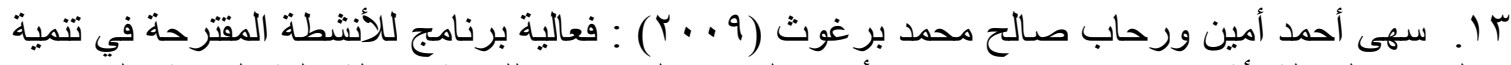

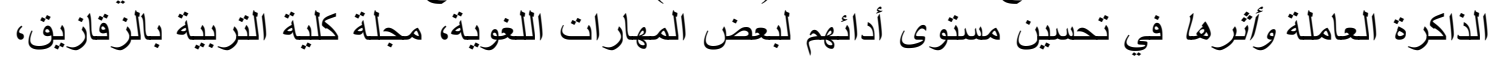

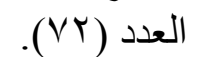

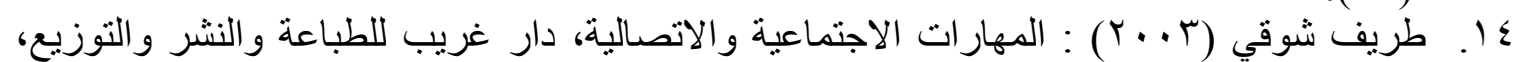

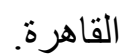

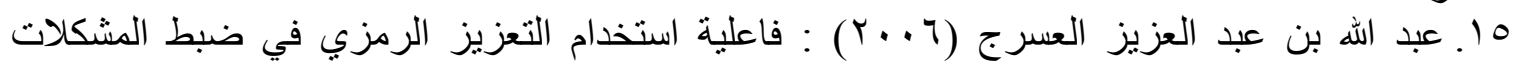

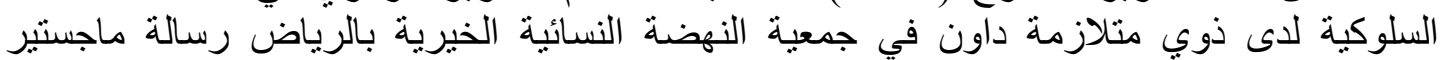

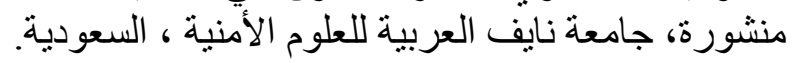

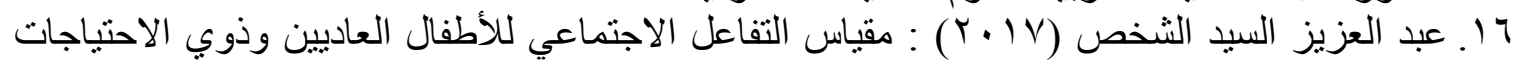

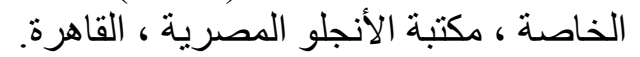

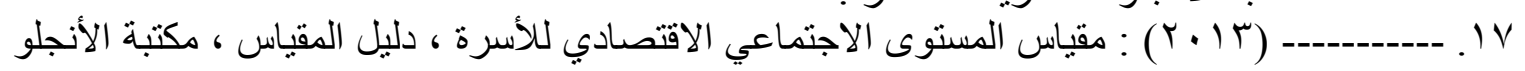
المصرية ، القاهرة.

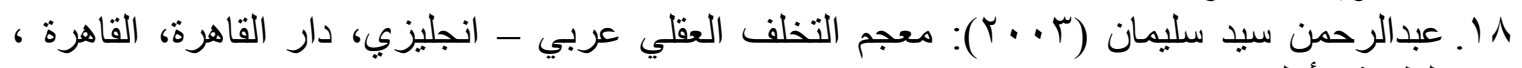
الطبعة الأولى. الطئ

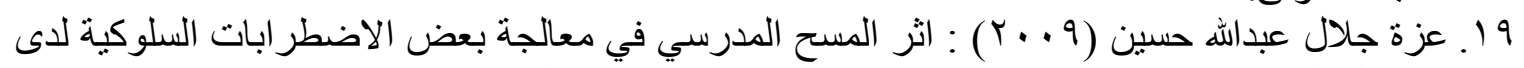

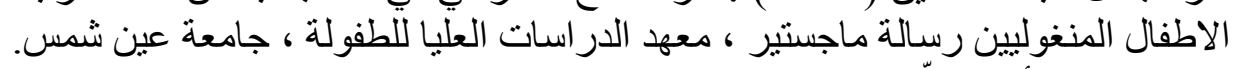

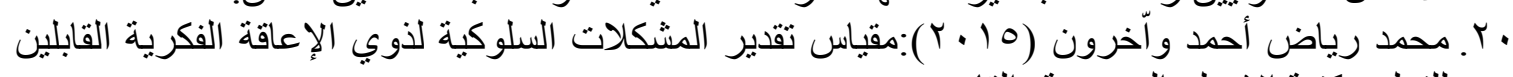
للتعلم،مكتبة الانجلو المصرية ،القاهرة

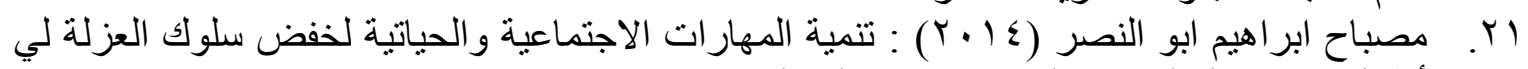

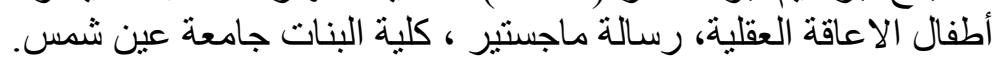

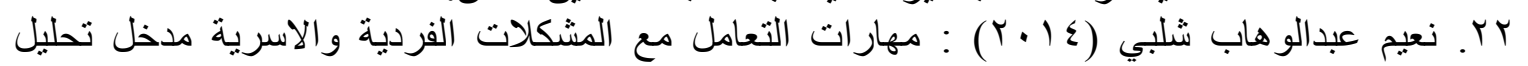

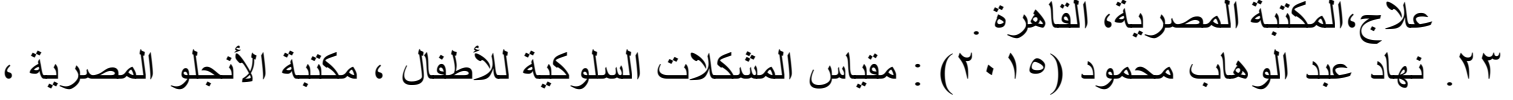
القاهرة.

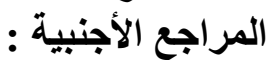

24. Alvey, G. L., \& Aeschleman, S. R. (1990). Evaluation of parent training programme for teaching Mentally Retarded children age appropriate restaurant skills a preliminary investigation. Journal of Mental Deficiency Research, Vol. 34, pp. 421-428.

25. Bellini, J. (2007). Commentary on Simon and Lichten's "Defining Mental Retardation: A Matter of Life and Death". Intellectual and Developmental Disabilities, 45 (5), 347-350.

26. Bernstein D.A., Penner, L.A. Stewart, A.C. and Roy, E.J. (2003): Psychology, 6 ed. USA : Houghton Mifflin Company.

27. Buckley S (1993): Language development in children with Down's syndrome: Reasons for optimism. "Down's Syndrome: Research and practice." 1:3-9.

28. Evelyn H. Kroesbergen \& Johannes E.H. Van Luit (2003) Mathematics Interventions for children with special educational needs. Remedial and Special Education, vol 24, No.2, march - April 3 pp.97-105. 

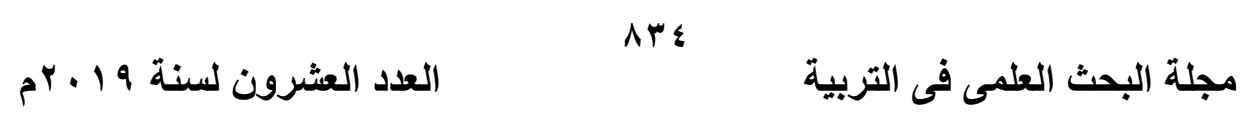

29. Frenkel S., Bourdin, B. (2009) : Verbal, visual and spatio-sequential shortterm memory: assessment of the storage capacities of children and teenagers with down syndrome. Journal of intellectual disability Research, Vol. (53), P (2), pp 152-160.

30. Morrison, J. (2009): Adults with Intellectual Disabilities: Prevalence, Incidence and Remission of Aggressive Behavior and Related Factors, Journal of Intellectual Disability Research, 53(3), 217-232.

31. O, Connor, J. and Frankel, F. (2006) : A controlled social skills training for children with fetal alcohol spectrum disorders, journal of consulting and clinical psychology, V. 64, No. 9, pp 634-648.

32. Patterson, D. and Costa, A.C. (2005) : Down syndrome and genetics. A case of linked histories, Nature Reviews Genetics, Vol. 6, No. 1 pp 137-147.

33. Patterson, D. and Costa, A.C. (2005) : Down syndrome and genetics. A case of linked histories, Nature Reviews Genetics, Vol. 6, No. 1 pp 137-147.

34. Riggio R.E (1986) : Assessment of basic social skills, J of personality and social psychology, Vol. 5, No. 3. P. 15. 